\begin{abstract}
UNIVERSIDADE DE SÃO PAULO
FACULDADE DE FILOSOFIA, LETRAS E CIÊNCIAS HUMANAS

DEPARTAMENTO DE LETRAS MODERNAS

PROGRAMA DE PÓS-GRADUAÇÃO EM ESTUDOS LINGUÍSTICOS E LITERÁRIOS EM INGLÊS
\end{abstract}

SÉRGIO MARRA DE AGUIAR

As vozes de Chico Buarque em inglês: Tradução e Linguística de Corpus

São Paulo 


\author{
UNIVERSIDADE DE SÃO PAULO \\ FACULDADE DE FILOSOFIA, LETRAS E CIÊNCIAS HUMANAS \\ DEPARTAMENTO DE LETRAS MODERNAS \\ PROGRAMA DE PÓS-GRADUAÇÃO EM ESTUDOS LINGUÍSTICOS E \\ LITERÁRIOS EM INGLÊS
}

SÉRGIO MARRA DE AGUIAR

As vozes de Chico Buarque em inglês: Tradução e Linguística de Corpus Tese apresentada à Faculdade de Filosofia,
Letras e Ciências Humanas da USP, para a
obtenção do título de Doutor em Estudos
Linguísticos e Literários em Inglês, sob a
orientação da Profa. Dra. Stella Ortweiller
Tagnin.

São Paulo 
(Ficha catalográfica) 


\title{
As vozes de Chico Buarque em inglês: Tradução e Linguística de Corpus
}

\author{
Tese apresentada à Faculdade de Filosofia, \\ Letras e Ciências Humanas da USP, para a \\ obtenção do título de Doutor em Estudos \\ Linguísticos e Literários em Inglês, sob a \\ orientação da Profa. Dra. Stella Ortweiller \\ Tagnin.
}

Banca Examinadora:

São Paulo, de de 2011.

Prof. Dr. Lourdes Bernardes Gonçalves - UFC

Prof. Dr. Anthony Berber Sardinha - PUC-SP

Profa. Dra. Lenita Rímoli Esteves - USP

Prof. Dr. John Milton - USP

Profa. Dra. Stella Ortweiller Tagnin - Orientadora 
Para Daniel e Luana, que me traduzem o significado da vida todos os dias. 


\section{Agradecimentos}

À Profa. Dra. Stella E. O. Tagnin, pela inestimável orientação, pela confiança em mim depositada e pelo incentivo constante;

Aos Professores John Milton e Carmem Dayrell, pelas contribuições no exame de qualificação;

À CELIN do Instituto de Letras e Linguística da Universidade Federal de Uberlândia, pela liberação de minhas atividades acadêmicas para a realização desta pesquisa;

Ao autor Chico Buarque de Hollanda, por ter me recebido para uma entrevista sobre as traduções de suas obras literárias;

Aos tradutores Alison Entrekin, Clifford Landers e Peter Bush, as vozes de Chico Buarque em inglês, por terem gentilmente concordado em conversar sobre suas traduções;

À editora Liz Calder, pela entrevista a mim concedida;

À CAPES, pela concessão da bolsa sanduíche para a realização de um estágio no Programa de Dourado em Translation and Intercultural Studies da Universitat Rovira i Virgili, Tarragona, Espanha, sob a supervisão do Prof. Dr. Anthony Pym.;

Ao Prof. Dr. Anthony Pym, pela orientação durante o estágio da bolsa sanduíche realizado na Universitat Rovira i Virgili;

Aos Profs. Itamar Even-Zohar e Harish Trivedi, pelas sessões de orientação realizadas durante o Spring Seminar promovido pelo Intercultural Studies Group do Departamento de Filologia Anglogermânica da Universitat Rovira e Virgili, em maio de 2008;

A todos os colegas do Projeto COMET, USP, SP, pela amizade, solidariedade, cooperação acadêmica e também pelos memoráveis momentos de descontração;

Às estimadas colegas e amigas Profas. Betina Rodrigues da Cunha, Daisy Rodrigues do Vale, Paula Arbex e Vera Santiago, pelas interlocuções e pelas diferentes e especiais formas com que me apoiaram durante esta trajetória;

Ao Fernando e ao Altair Jr., pelo valioso suporte técnico;

Aos amigos, pelo incentivo permanente;

À minha família, pelo carinho, pelo apoio incondicional e por compreender as minhas ausências. 
[ ...] in the course of my experience as a translated author I have always been torn between the need to have a translation that respected what I believed to be my intentions, and the exciting discovery that my text, independently of my early intentions, could elicit unexpected interpretations and be in some way improved when it was re-embodied in another language.

Umberto Eco (Mouse or Rat? Translation as negociation) 


\section{RESUMO}

O notável talento de Chico Buarque em lidar com as palavras, assim como sua participação nas traduções de suas obras literárias para o inglês, são o fio condutor desta pesquisa de doutorado, em que se investigaram as traduções de Estorvo, Benjamim e Budapeste. A Linguística de Corpus foi utilizada como base metodológica para investigação do corpus de estudo, composto pelas referidas obras originais e traduzidas. Utilizando-se o programa computacional WordSmith Tools, de Mike Scott, foi extraída do corpus de estudo, uma lista de palavras-chave que serviu como ponto de partida para uma análise qualitativa das traduções, focando o aspecto da recuperação da criatividade lexical do autor pelos tradutores. Os resultados desta análise levaram a crer que houve, por parte dos tradutores, Peter Bush, Clifford Landers e Alison Entrekin, um empenho significativo para recriar as supostas intenções semânticas e estilísticas do escritor. Tal conclusão foi corroborada por entrevistas que este pesquisador conduziu com o autor, com os três tradutores e com a editora Liz Calder. A Linguística de Corpus, por sua vez, mostrou-se eficaz não só como metodologia para exploração de um corpus literário, mas também como uma abordagem, na medida em que revelou aspectos das traduções que não se havia cogitado investigar.

Palavras-chave: Tradução. Linguística de Corpus. Tradução Literária. Criatividade lexical. Chico Buarque. 


\begin{abstract}
Chico Buarque's notable talent in dealing with words as well as his participation in the translations of his books into English are the core of this doctoral dissertation, which investigated the translations of Estorvo (Turbulence), Benjamim (Benjamin) and Budapeste (Budapest) into English. Corpus Linguistics was used as a methodological basis for investigating the study corpus, constituted by both original and translated works. With the computer program WordSmith Tools, developed by Mike Scott, a list of keywords was extracted from the corpus, which served as a starting point for a qualitative analysis of the translations. The focus was to investigate if the author's creativity was recovered by his translators. The results led to believe that the translators, Peter Bush, Clifford Landers and Alison Entrekin, made a significant effort to recreate Chico Buarque's semantic and stylistic endeavors. This conclusion was corroborated by the oral interviews conducted by this researcher with the author, the three translators and the publisher Liz Calder. Corpus Linguistics, in turn, was effective not only as a methodology to explore a literary corpus, but also as an approach to the extent that it revealed aspects of the translations that were not previously considered worthy of invetigation.
\end{abstract}

Keywords: Translation. Corpus Linguistics. Literary Translation. Lexical creativity. Chico Buarque. Translators. 


\section{LISTA DE FIGURAS}

Figura 1 - Trinta primeiros vocábulos do Corpus de Estudo Português Original.

Figura 2 - Trinta primeiras palavras-chave do Corpus de Estudo Português Original.

Figura 3 - Tela do Setting KEYWORDS

Figura 4 - Concordance da palavra de busca "olhos" do corpus de estudo português original

Figura 5 - Alinhamento dos textos original e traduzido do romance Budapeste.

Figura 6 - Resultado parcial do Parallel Search com as palavras "olhos" e "eyes" nos corpora paralelos, compostos pelos textos originais e traduzidos do romance Budapeste.

Figura 7 - Alinhamento feito com o software ParaConc de parte do primeiro capítulo do romance Budapeste nas versões original e traduzida.

\section{LISTA DE TABELAS}

Tabela 1 - Dados estatísticos do corpus de estudo em português original. ESTPO = Estorvo Português Original, BENPO $=$ Benjamim Português Original e BUDPO = Budapeste Português Original.

Tabela 2 - Dados estatísticos do corpus de estudo em inglês original. ESTIT = Estorvo Inglês Traduzido, BENIT = Benjamim Inglês Traduzido e BUDIT = Budapeste Inglês Traduzido.

Tabela 3 - Palavras pertencentes ao campo semântico do corpo humano no corpus de estudo em português original.

Tabela 4 - Palavras pertencentes ao campo semântico do corpo humano no corpus de estudo em inglês traduzido.

Tabela 5 - Primeiras treze palavras-chave pertencentes ao campo semântico do corpo humano no corpus de estudo em português original (kwcepo2.kws, anexo 2.24) comparado com o corpus de referência Lácio-Web Geral.

Tabela 6 - Primeiras seis palavras-chave pertencentes ao campo semântico do corpo humano no corpus de estudo em inglês traduzido (kwceit1. kws) comparado com o corpus de referência Brown.

Tabela 7 - Primeiras 14 palavras-chave pertencentes ao campo semântico do corpo humano no corpus de estudo em português original (kwcepo3. kws, anexo 2.24) comparado com o corpus de referência Banco de Português.

Tabela 8 - Primeiras sete palavras-chave pertencentes ao campo semântico do corpo humano no corpus de estudo em inglês traduzido (kwceit2. kWs, anexo 2.26) comparado com o corpus de referência BNC.

Tabela 9 - Palavras-chave pertencentes ao campo semântico das partes do corpo humano na obra Estorvo.

Tabela 10 - Palavras-chave pertencentes ao campo semântico das partes do corpo humano na obra Estorvo com chavicidade $=$ ou $>50$.

Tabela 11 - Palavras chaves pertencentes ao campo semântico das partes do corpo humano na obra Estorvo com chavicidade $=$ ou $>50$, classificadas entre as 90 primeiras da Kwestpo3.kws (anexo 3.1)

Tabela 12 - Palavras-chave pertencentes ao campo semântico das partes do corpo humano na obra Benjamim. 
Tabela 13 - Palavras-chave pertencentes ao campo semântico das partes do corpo humano na obra Benjamim com chavicidade $=$ ou $>50$.

Tabela 14 - Palavras chaves pertencentes ao campo semântico das partes do corpo humano na obra Benjamim com chavicidade $=$ ou $>50$, classificadas entre as 90 primeiras da Kwbenpo3.kws (anexo 3.2).

Tabela 15 - Palavras-chave pertencentes ao campo semântico das partes do corpo humano na obra Budapeste.

Tabela 16 - Palavras-chave pertencentes ao campo semântico das partes do corpo humano na obra Budapeste com chavicidade $=$ ou $>50$.

Tabela 17 - Palavras chaves pertencentes ao campo semântico das partes do corpo humano na obra Budapeste com chavicidade $=$ ou $>50$, classificadas entre as 90 primeiras da Kwbudpo3.kws (anexo 3.3).

Tabela 18 - Palavras-chave pertencentes ao campo semântico das partes do corpo humano na obra com chavicidade $=$ ou $>50$, classificadas entre as 90 primeiras palavras da Kwestpo3.kws (anexo 3.1).

Tabela 19 - Palavras-chave pertencentes ao campo semântico das partes do corpo humano na obra com chavicidade $=$ ou $>50$, classificadas entre as 90 primeiras palavras da Kwbentpo3.kws (anexo 3.2).

Tabela 20 - Palavras-chave pertencentes ao campo semântico das partes do corpo humano na obra com chavicidade $=$ ou $>50$, classificadas entre as 90 primeiras palavras da Kwbudpo3.kws (anexo 3.3).

Tabela 21 - Palavras-chave pertencentes ao campo semântico das partes do corpo humano que se repetem nas obras Estorvo, Benjamim e Budapeste com chavicidade $=$ ou $>50$, classificadas entre as 90 primeiras palavras-chave de suas respectivas listas de palavraschave.

Tabela 22 - Dados estatísticos referente aos números absolutos e percentuais das palavraschave, no português original e no inglês traduzido, que pertencem ao campo semântico do corpo humano (€ C.S) na obra Estorvo, no português original (PO) e no inglês traduzido (IT).

Tabela 23 - Dados estatísticos referente aos números absolutos e percentuais das palavraschave, no português original e no inglês traduzido, que pertencem ao campo semântico do corpo humano (€ C.S) na obra Benjamim, no português original (PO) e no inglês traduzido (IT).

Tabela 24 - Dados estatísticos referente aos números absolutos e percentuais das palavraschave, no português original e no inglês traduzido, que pertencem ao campo semântico do corpo humano (€ C.S) na obra Budapeste, no português original (PO) e no inglês traduzido (IT).

Tabela 25 - Frequência (Freq.) total das palavras-chave, no português original e no inglês traduzido, nas obras Estorvo, Benjamim e Budapeste, no português original ( $\mathrm{PO}$ ) e no inglês traduzido (IT).

Tabela 26 - Recuperação das combinações criativas nas obras de Chico Buarque pelos seus tradutores. 


\section{LISTA DE QUADROS}

Quadro 1 - Corpora de referência de Língua Portuguesa

Quadro 2 - Corpora de referência de Língua Inglesa

Quadro 3 - Corpora de contraste para as obras em Português

Quadro 4 - Corpora de contraste para as obras em Inglês

Quadro 5 - Relação das ocorrências da palavra-chave "olhos" e suas respectivas traduções do português na obra Budapeste.

Quadro 6 - Relação das ocorrências da palavra-chave "head" e suas respectivas traduções do português na obra Budapest.

\section{LISTA DE ABREVIATURAS E SIGLAS}

BNC - British National Corpus

BUDIT - Budapeste Inglês Traduzido

LC - Linguísitica de Corpus

Cdp - Corpus do Português

COCA - Corpus of Contemporary American English

ESTIT - Estorvo Inglês Traduzido

BENPO - Benjamim Português Original

BENIT - Benjamim Inglês Traduzido

BUDPO - Budapeste Português Original

ESTPO - Estorvo Português Original

Freq. - Frequência

Chav. - Chavicidade

KWCEPO - Key Words Corpus de Estudo Português Original

KWCEIT - Key Words Corpus de Estudo Inglês Traduzido

WL - Word List

KW - Key Word

KWL - Key Word List

WST - WordSmith Tools 


\section{SUMÁRIO}

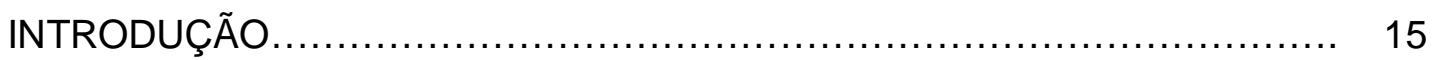

Chico Buarque: o torneador de palavras........................................ 18

Chico Buarque: o partícipe das traduções................................................... 20

O Interesse pelo tema da pesquisa............................................... 21

A Linguística de Corpus aplicada à exploração e análise de um corpus

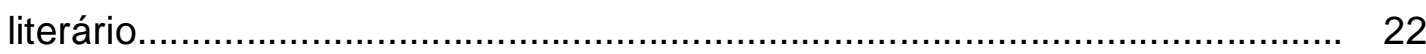

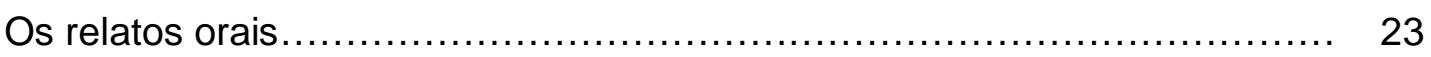

A formulação da hipótese...................................................... 26

Os objetivos da pesquisa........................................................ 27

A estrutura da tese

CAPÍTULO I - A trajetória literária de Chico Buarque e suas participações nas traduções de suas obras............................................................... 30

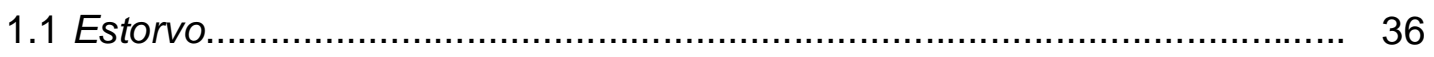

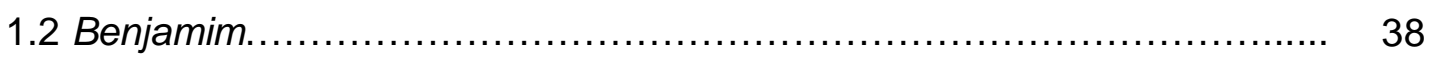

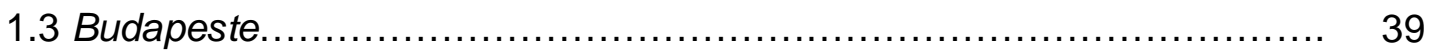

1.4 Chico Buarque e tradução.................................................................... 42

CAPÍTULO II - As vozes de Chico Buarque em inglês: Bush, Landers e Entrekin 50

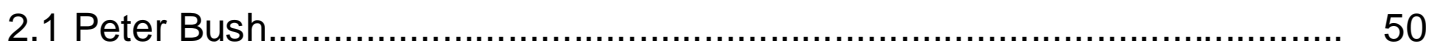

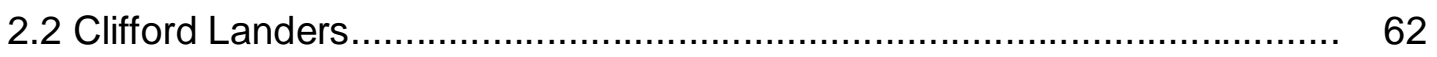

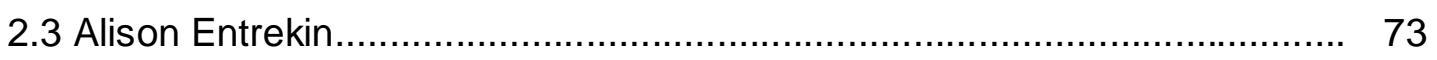

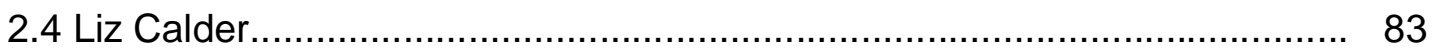

CAPÍTULO III - A Linguística de Corpus e sua interface com a tradução........ 91

3.1 A Linguística de Corpus e as ferramentas computacionais utilizadas na corpora desta pesquisa .................................................................... 91

3.2 A Linguística de Corpus é uma metodologia ou uma abordagem?........... 92

$3.3 \mathrm{O}$ que é um corpus? .................................................................... 94

3.4 Os diferentes tipos de corpora....................................................... 95

3.5 O programa para a análise de dados - WordSmith Tools....................... 100

3.6 O software ParaConc...................................................................... 107 


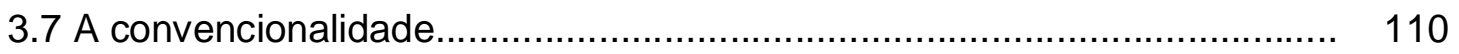

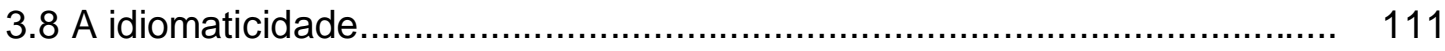

3.9 A convencionalidade nos níveis sintático e semântico................................ 113

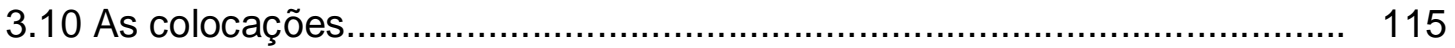

3.11 Colocados criativos: manipulação linguística e criatividade...................... 116

CAPÍTULO IV - Metodologia............................................................... 118

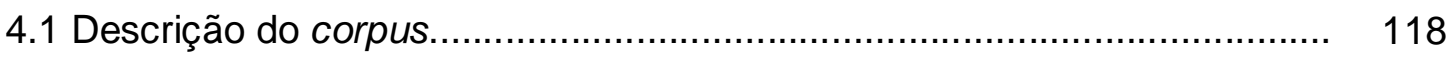

4.2 Procedimentos de Análise do Corpus.................................................. 121

4.3 Levantamento das Word Lists (WL) - Listas de Frequência..................... 121

4.4 KeyWords: O que elas podem revelar?................................................ 124

4.5 Os romances buarqueanos comparados entre si.................................... 129

4.6 Seleção e investigação das palavras-chave: etapas e procedimentos...... 130

4.7 O que foi evidenciado a partir da comparação das frequências das palavras-chaves nas obras originais e nas traduções? .................................. 139

4.8 Descobertas a partir do cotejo dos originais com as traduções no sentido

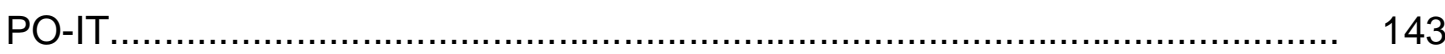

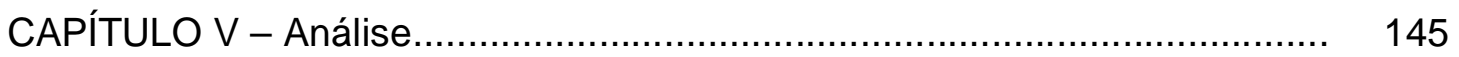

5.1 Aspectos sobre as estratégias utilizadas pelos tradutores que foram revelados em decorrência dessa investigação no sentido inverso, ou seja, inglês - português.

5.2 Perdas e Ganhos: convencionalidade e tradução

5.3 Colocados criativos: quando "os olhos fogem do assunto"........................ 162

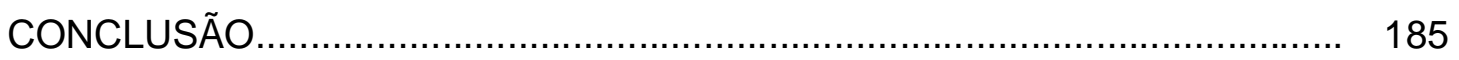

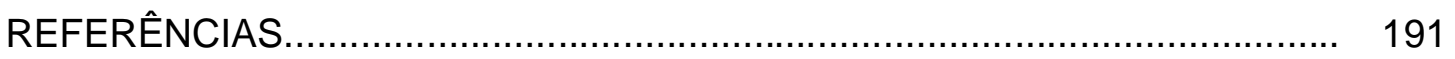

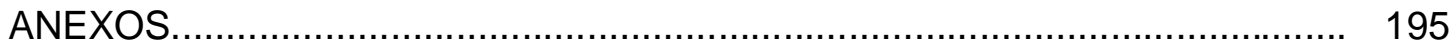

Anexo 1 - Roteiro da entrevista com Clifford Landers

Anexo 2 - Word Lists (Listas de Frequência de palavras)

Anexo 3 - KeyWord Lists (Listas de Palavras-chave) 
Anexo 4 - Capas: segunda edição de Estorvo, 2004, primeira edição de Benjamim (1995), segunda edição de Budapeste, 2005

Anexo 5 - Capa e folha de rosto: segunda edição de Turbulence, 1997

Anexo 6 - Capa e folha de rosto: segunda edição de Benjamin, 1998

Anexo 7 - Capa e folha de rosto: primeira edição de Budapest, 2004 


\title{
INTRODUÇÃO
}

\begin{abstract}
Muito se perde em uma tradução literária, isto é incontestável. Mas o que se ganha? Todo um novo livro. Nenhuma perda na tradução é relevante o bastante para compensar o ganho que se tem com ela.
\end{abstract}

Harish Trivedi ${ }^{1}$

O interesse pelo estudo das traduções para o inglês da obra literária de Chico Buarque deve-se, primeiramente, a sua incontestável importância como compositor e escritor para a cultura brasileira. Buarque é considerado o maior compositor de música popular do Brasil das últimas cinco décadas; sua obra é permeada pela história deste país desde a década de 60. Como afirma Silva (2004, p. 8-9), a criação de Chico Buarque

[...] não apenas registra a nossa história, como frequentemente a revela para nós sob ângulos insuspeitados, amarrando e comunicando a experiência coletiva aos segredos e abismos da subjetividade de cada um. É o inconsciente do país que parece falar na rede simbólica que Chico nos estendeu ao logo dos anos.

O autor da marchinha "A Banda" que, em 1966, juntamente com "Disparada", venceu o II Festival de MPB da TV Record, e de outras inúmeras e memoráveis canções foi, em 1967, definido por Millôr Fernandes como "a única unanimidade nacional”. Desde então, Chico Buarque, além da música, transita nos campos da dramaturgia, cinema e literatura, sendo elogiado, mas também criticado, principalmente por suas peças e livros. Falta de consenso à parte, o fato é que poucos artistas nacionais contribuíram e continuam a contribuir de forma tão expressiva para a cultura brasileira como Chico Buarque. O Brasil possui uma música popular que é, reconhecidamente, e sob

\footnotetext{
${ }^{1}$ Citação extraída da palestra "The nature of literary translation", proferida em 21/05/2008, na Universitat de Rovira I Virgili, como parte do Spring Seminar promovido pelo PhD in Translation and Intercultural Studies, sob a coordenação de Anthony Pym.
} 
diversos aspectos uma das melhores do mundo. Chico Buarque é, sem dúvida, um de seus representantes mais conhecidos e respeitados no exterior, onde nossa música goza de notável prestígio.

Esse ídolo popular da década de 70, já com mais de sessenta anos, continua atual e presente em nosso cenário cultural, seja como compositor ou escritor. As canções, do início de sua carreira, ainda encantam gerações mais novas nascidas e embaladas ao som de músicas tão diversas das suas. Ouvido e lido por gerações de idades e perfis variados, Chico Buarque possui uma das maiores comunidades do Orkut no Brasil, tendo mais de cem mil seguidores no seu Twitter; é, inclusive, citado por blogueiros adolescentes e está cada vez mais visível nos espaços da rede virtual.

Tais fenômenos midiáticos mostram que se trata de um compositor cuja obra se consolida, cresce e se renova desde sempre, e de um autor, cuja produção literária - embora seja quantitativamente pequena e recente: quatro romances nas últimas décadas - é considerada uma das mais relevantes da literatura brasileira contemporânea, sendo reconhecida, sobretudo, pelas ousadias criativas e estratégias discursivas. José Saramago ao escrever sobre o romance Bupadeste (2003), afirma:

Chico Buarque ousou muito, escreveu cruzando um abismo sobre um arame e chegou ao outro lado. Ao lado onde se encontram os trabalhos executados com mestria, a da linguagem, a da construção narrativa, a do simples fazer. Não creio enganar-me dizendo que algo novo aconteceu no Brasil com este livro.

Como escritor, Chico Buarque ressurgiu ${ }^{2}$ no cenário literário brasileiro com a publicação de Estorvo em 1991; Benjamim em 1995; Budapeste em 2003 e "Leite Derramado" em 2009. Em 1992, as traduções de Estorvo foram

\footnotetext{
${ }^{2}$ Chico Buarque havia publicado outras obras, como Fazenda Modelo (1974) e Chapeuzinho Amarelo (1979), que serão mencionadas e comentadas no Capítulo I.
} 
publicadas na Noruega, Dinamarca, Holanda, França, Espanha e Inglaterra, dando, assim, início à sua trajetória internacional como escritor.

$\mathrm{Na}$ Inglaterra, sua obra foi publicada pela editora Bloomsbury. Estorvo foi traduzido pelo britânico Peter Bush em 1992, e recebeu o título Turbulence; em seguida, vieram Benjamim, em 1997, traduzido pelo americano Clifford Landers, e Budapeste, em 2004, traduzido pela australiana Alison Entrekin.

Vale lembrar que esse reconhecimento aconteceu também no exterior, como, inclusive aponta Maria Lúcia Daflon (2009, p.119): "Chico Buarque, aliás, é hoje um expoente internacional da literatura brasileira. Os livros de Buarque, especialmente Budapeste, têm boa vendagem, embora dentro dos limites dos vôos que a literatura brasileira pode alcançar no exterior."

No lançamento de Estorvo na Inglaterra em 1992, o jornal britânico The Independent ressaltou a técnica criativa do autor e comparou a sua narrativa a uma improvisação de jazz ${ }^{3}$. Ainda sobre o livro Estorvo, o jornal New Statesman apontou o brasilianismo do texto de Chico Buarque e o comparou a um dos livros de Joyce ${ }^{4}$. A complexidade da narrativa do autor presente no romance Benjamim foi ressaltada pelo jornal Sunday Times ${ }^{5}$. O prestígio do escritor, além de nossas fronteiras, também pode ser comprovado pela inclusão do romance Budapeste na lista do jornal The Independent entre os melhores livros lançados em 2004, na Grã-Bretanha, e pelo recebimento do prêmio "Dois Oceanos" no Festival de Biarritz, na França, em setembro de 2005.

\footnotetext{
3 "An intriguing cross-fertilisation of creative technique in a narrative as unpredictable as a sustained passage of jazz improvisation."

4 "An unmistakably Brazilian text. A little like Ulysses turned inside out."

5 "A dreamlike and labyrinthine narrative with a thriller plot revving in the background."
} 


\section{Chico Buarque: o "torneador de palavras"}

Como bem definiu Regina Zappa (2004), em seu ensaio intitulado "Vertigem", Chico é "um obsessivo torneador de palavras" e a sua devoção a elas é uma de suas características marcantes. Esse cuidado em burilar as palavras como parte do processo de criação literária, é também ressaltado por Sales (2004, p. 207), no ensaio "A literatura do Estorvo": "a palavra é matériaprima básica em todos os caminhos que a arte de Chico Buarque tomou [...]".

Cabe salientar que a referida devoção às palavras, característica marcante de Buarque, encontra-se presente, também, na sua obra ficcional. Ela é comum ao protagonista de seu terceiro romance, Budapeste, o ghost writer José Costa: "De tanto me devotar ao meu ofício, escrevendo e reescrevendo, corrigindo e depurando textos, mimando cada palavra que punha no papel, já não me sobravam boas palavras para ela".

O próprio Chico Buarque fala de seu interesse pelas palavras no texto intitulado "Os dicionários de meu pai", publicado na segunda edição do Dicionário Analógico da Língua Portuguesa, de Azevedo (2010). No texto que antecede o prólogo, Chico Buarque relata que ao receber de seu pai a primeira edição desse dicionário, datada de 1950, herdou não só o livro, mas também o apreço pelas palavras: "Era como se ele, cansado, me passasse um bastão que de alguma forma eu deveria levar adiante". Segundo Buarque, "palavra puxa palavra, e escarafunchar o dicionário analógico" tornou-se para ele "um passatempo".

Em um artigo publicado na Folha de S. Paulo, em 19/10/1991, seu pai, o historiador Sérgio Buarque de Holanda, escreveu que Guimarães Rosa era um dos autores preferidos de Chico Buarque, e, talvez inspirado em Guimarães 
Rosa, "que também era dado a inventar palavras", inventou a palavra "penseiro", que faz parte da letra da canção "Pedro Pedreiro", composta em 1965. Tal admiração pelo escritor mineiro está, também, registrada no DVD "Chico Buarque - Uma Palavra"6, em que declara que "queria ser Guimarães Rosa". Sobre a força da palavra, Buarque afirma, nesse mesmo depoimento, que "a palavra é mais forte que o criador" e nos "conduz por caminhos inesperados".

Como exemplo de sua obsessão pela palavra, pode-se citar o episódio descrito por Chico Buarque, em uma entrevista concedida à revista Ocas (24/07/2004), na qual relata que suspendeu, depois de tudo pronto, a prensa de um disco porque decidiu trocar uma única palavra de uma letra, que já estava inclusive impressa.

Outro exemplo de seu esmero na escolha do léxico refere-se à manutenção ou quebra da convencionalidade linguística na tradução. Buarque afirma que esse assunto foi motivo de disputa com os tradutores: "briguei muito por isso várias vezes". O autor cita um exemplo a ilustrar muito bem essa questão: "No Estorvo, eu dizia, em determinada hora, que o sujeito entrava no botequim, entrava num banheiro que tinha um cheiro pesado." $O$ tradutor insistia em traduzir "cheiro pesado" por "cheiro forte" (strong smell) sob a alegação de que não existe "cheiro pesado" (heavy smell) em inglês. O autor contra argumentava insistindo que "cheiro pesado" não é uma colocação convencional em português e que em português "não existe cheiro pesado, mas o que eu quero dizer é cheiro pesado". Neste caso, a quebra da convencionalidade foi intencional.

\footnotetext{
${ }^{6}$ Este DVD faz parte da série retrospectiva da obra de Chico Buarque, lançado pela EMI em 2006.
} 
Segundo Chico Buarque, ele "queria fugir do lugar comum" e a tradução por "cheiro forte" "caía no clichê, caía no lugar comum", ou seja, a criatividade do autor, ao promover esse jogo linguístico por meio da quebra da convencionalidade, não seria mantida na tradução. Nesse caso, na tradução optou-se por "heavy smell", mantendo, dessa forma, a quebra intencional da convencionalidade:

ESTPO: "No extremo do balcão, um corredor que só se atravessa andando de lado leva a um mictório com um cheiro muito pesado."
ESTIT: "At the end of the counter, a passage you can only walk along sideways leads to a lavatory with a heavy smell."

\section{Chico Buarque: o partícipe das traduções}

Chamou a atenção deste pesquisador o fato de o autor ter colaborado com os tradutores de seus romances para o inglês, francês, italiano e espanhol, línguas com as quais possui familiaridade. A participação de Chico Buarque nessas traduções deve-se, em princípio, ao fato de ele ser conhecedor dessas línguas; ao cuidado que o autor demonstra ter por suas criações; e ao direito que, segundo ele, Ihe é reservado como autor da obra, conforme relatou em entrevista concedida a este pesquisador em 22/09/2008. Percebe-se, então, que existe por parte do autor um apego a sua obra e um desejo de controle sobre as escolhas dos tradutores.

A disputa de Chico Buarque com o tradutor Peter Bush acerca da tradução de "cheiro pesado", acima relatada, mostra a intensidade da participação do autor em algumas das traduções de sua obra. As conversas que mantivemos com o autor e com os profissionais tradutores para a língua 
inglesa revelaram que sua colaboração foi muito expressiva. A forma e o nível de interação, com os tradutores, variaram devido ao fato de as traduções terem ocorrido em diferentes épocas e contextos.

Durante a tradução de Estorvo, o contato com o tradutor se deu via fax e, principalmente in loco, na ocasião em que Chico Buarque esteve em Londres; com o tradutor Clifford Landers o contato se deu ao telefone e também via fax; já com Alison Entrekin, grande parte do diálogo ocorreu pela troca de e-mails, pois, nessa época, o autor já tinha se tornado usuário da internet.

\section{O interesse pelo tema da pesquisa}

Além da já mencionada indubitável importância de Chico Buarque para a cultura brasileira, a certeza de se escolher as traduções da obra literária de Chico Buarque para o inglês como objeto de pesquisa se deu com base na sua característica marcante de "torneador de palavras" e no fato de o autor ter atuado como partícipe nas traduções de suas obras literárias. A possibilidade, de dialogar com o autor e com os tradutores sobre as traduções de suas obras, contribuiu ainda mais para fortalecer o desejo de realizar esta pesquisa.

Como resultado desse interesse, decidiu-se, então, fazer uma pesquisa das traduções, para o inglês, das obras Estorvo, Benjamim e Budapeste, de autoria de Chico Buarque de Hollanda, pelos tradutores Peter Bush, Clifford E. Landers e Alison Entrekin, respectivamente. Devido à extensão do material a ser analisado, optou-se pelo uso da base metodológica da Linguística de Corpus para desenvolver a investigação do referido corpus. 


\title{
A Linguística de Corpus aplicada à exploração e análise de um corpus literário
}

Para desenvolver a análise do corpus composto pelas referidas obras e suas respectivas traduções, foi utilizada a base metodológica da Linguística de Corpus (LC). Segundo Berber Sardinha (2004, p. 3), a LC

\begin{abstract}
ocupa-se da coleta e da exploração de corpora, ou conjuntos de dados linguísticos textuais coletados criteriosamente, com o propósito de servirem para a pesquisa de uma língua ou variedade linguística. Como tal, dedica-se à exploração da linguagem por meio de evidências empíricas, extraídas por computador.
\end{abstract}

A partir dessa base metodológica, é possível viabilizar análises de grandes corpora, que antes eram inviáveis pelo cotejo manual. A contagem dos padrões léxico-gramaticais que caracterizam um corpus de milhões de palavras, por exemplo, seria impossível, ou no mínimo imprecisa, sem a ajuda de uma base metodológica computacional.

No artigo intitulado "A Linguística de Corpus no Brasil”, Berber Sardinha e Almeida (2008), ressaltam o aspecto interdisciplinar da LC e o seu crescimento em todo o mundo, inclusive no Brasil. A LC, segundo os autores, é aplicada na área da Lexicografia e em trabalhos de Linguística Aplicada, Processamento de Língua Natural e Tradução. Cabe mencionar que, além das disciplinas citadas pelos autores, a LC vem ganhando espaço, também, na área de estudos literários, nas palavras de Bernardes Gonçalves (2008, p. 387), a LC "se evidencia imediatamente como uma metodologia extremamente facilitadora do trabalho de pesquisadores e críticos literários”.

Sobre a sua interface com a Tradução, Berber Sardinha (2002) afirma que a utilização dessa base metodológica pode ser útil tanto para a prática tradutória quanto para a pesquisa na área da tradução. Dentre as vantagens 
oferecidas pela Linguística de Corpus, pode-se destacar: 1) as evidências que os corpora podem revelar em termos linguísticos e 2) os insights sobre a natureza de aspectos discursivos relacionados ao processo tradutório.

Nesta pesquisa de doutorado, a LC ofereceu uma metodologia que possibilitou - por meio do uso do programa computacional WordSmith Tools ${ }^{7}$ (WST) - identificar nas obras literárias de Chico Buarque a presença do campo semântico de palavras que fazem parte do corpo humano. Essas palavras foram identificadas a partir de uma lista de palavras-chave, gerada automaticamente pelo WST e, posteriormente analisadas em contexto com as suas respectivas traduções para o inglês ${ }^{8}$.

Além de sua comprovada eficácia como metodologia, a pesquisa baseada nos corpora revelou aspectos dos originais e das traduções que não se cogitara pesquisar ${ }^{9}$, corroborando, desta forma, a afirmação de que a LC não se restringe a um conjunto de ferramentas computacionais, nem é apenas uma metodologia, mas também uma abordagem aplicável à exploração e análise de um corpus de estudo literário, composto por obras originais e suas respectivas traduções.

\section{Os relatos orais}

Nesta pesquisa, as fontes orais, constituídas pelas entrevistas realizadas com o autor, Chico Buarque, com Liz Calder, co-fundadora da Bloomsbury, e com os tradutores de suas obras literárias, Bush, Landers e Entrekin, são tidas como uma técnica. Meihy (2002, p. 45-46) explica que usar os depoimentos

\footnotetext{
${ }^{7}$ O programa computacional WordSmith Tools será descrito no Capítulo III.

${ }^{8} \mathrm{O}$ s critérios de seleção dessas palavras-chave para análise serão descritos no Capítulo IV.

${ }^{9}$ As descobertas feitas a partir da análise dos corpora serão detalhadas nos Capítulos IV e V.
} 
como uma técnica "equivale dizer que as entrevistas não se compõem como objetivo central e sim como um recurso a mais." Dessa forma, esses depoimentos são um complemento, um caminho a mais para o desenvolvimento da pesquisa e não o seu nervo.

O objeto central de investigação desta tese é o corpus de estudo, com as informações dele extraídas por meio das ferramentas computacionais. Contudo, cabe ressaltar que os relatos orais não são considerados menos científicos que os demais dados, devido a seu caráter subjetivo, pois, como argumenta Meihy (2002, p. 47), "a objetividade reclamada da história oral é a mesma que deve ser cobrada de qualquer outro documento escrito".

As informações coletadas nessas entrevistas são de considerável relevância para a análise do presente corpus de estudo, porque revelaram aspectos das traduções e do ato tradutório que não poderiam ser percebidos pela análise textual, ao mesmo tempo em que servem de contraponto entre o discurso e a prática dos tradutores ${ }^{10}$. Tahir-Gurçaglar (2002, p. 44), em seu artigo intitulado What Texts Don't Tell. The Use of Paratexts in Translation Research afirma que esse tipo material pode revelar fenômenos tradutológicos que não aparecem nas traduções ou que lá se encontram implicitamente, tais como diferentes conceitos de tradução em um determinado período, em um determinado contexto cultural.

Nesta pesquisa, o principal objetivo com relação às entrevistas foi a busca de informações e impressões sobre a experiência tradutória de cada um desses sujeitos, tradutores e autor, e não de verdades absolutas sobre a relação entre autor e tradutor, original e tradução. Como postula Meihy (2002,

\footnotetext{
${ }^{10}$ As informações subjacentes aos textos traduzidos reveladas pelas entrevistas serão tratadas na seção destinada às considerações finais sobre este trabalho.
} 
p. 49) "[...] o objetivo central da coleta de depoimentos não se esgota na busca da verdade e sim, na experiência". Pretendeu-se, também, estabelecer um diálogo dos depoimentos do autor e dos tradutores com as obras que compõem o corpus de estudo.

As referidas entrevistas foram gravadas pessoalmente por este pesquisador com os tradutores Clifford Landers, em julho de 2007, na cidade do Rio de Janeiro; com Alison Entrekin, em agosto do mesmo ano, em Santos; e, com Peter Bush, em junho de 2008, em Barcelona, Espanha. Chico Buarque foi entrevistado em setembro de 2008 , em sua residência no Rio de Janeiro e Liz Calder, em agosto de 2010, na cidade de Parati.

Os contatos com os dois primeiros tradutores entrevistados foram inicialmente feitos por indicação da professora Stella Tagnin e, com o último, por meio de um contato pessoal do professor Anthony Pym com o próprio tradutor; já os contatos com o autor e Liz Calder foram realizados em princípio pela tradutora Alison Entrekin. No início, foi pensado um modelo não estruturado de entrevista, no qual o entrevistador deixaria o entrevistado livre, sem seguir um roteiro pré-estabelecido. Contudo, Clifford Landers, o primeiro tradutor entrevistado, pediu que lhe fosse enviado o roteiro da entrevista, pois havia passado algum tempo desde que a tradução fora realizada e ele gostaria de refletir sobre algumas questões de sua tradução. As entrevistas que aconteceram posteriormente a essa seguiram praticamente o mesmo roteiro da primeira. (Anexo 1)

As cinco entrevistas, que perfazem um total de mais de cinco horas de gravação, foram registradas em fita cassete, usando o recurso DVR (Digital Voice Recorder) e posteriormente transcritas. Trata-se de um material rico em 
informações sobre o fazer tradutório, o relacionamento entre tradutor e autor, entre tradutor e editor, sobre a participação do autor nas traduções e as concepções de tradução literária de cada um desses sujeitos autorais.

Ao fazer uso da Linguística de Corpus e das entrevistas para análise do corpus de estudo, buscou-se uma sinergia entre o método assistido por ferramentas computacionais e a técnica baseada em relatos orais, de forma que um possa colaborar com o outro, e juntos contribuam para 0 desenvolvimento de uma análise mais abrangente.

\section{A formulação da hipótese}

A primeira leitura das traduções dos romances de Chico Buarque para o inglês, aliada a fatores, tais como a política editorial da Bloomsbury, focada na valorização da identidade e do estilo do autor; a importância artística de Chico Buarque; sua autoridade sobre seus textos, sua interação com os tradutores e participação nas traduções sugerem que as traduções de suas obras para o inglês sejam mais próximas dos originais, mesmo que o resultado possa soar um pouco excêntrico na língua de chegada. A partir desses elementos, apresenta-se a hipótese de que as traduções de Estorvo, Benjamim e Budapeste, na sua totalidade, buscam recuperar as intenções semânticas e estilísticas do autor, em especial, no que diz respeito a seus torneios com as palavras, que, muitas vezes, envolvem a quebra da convencionalidade na língua de chegada, podendo causar certo estranhamento ao leitor. Em outras palavras, esse estranhamento, também presente no original, funcionaria como um passaporte para que o leitor de língua inglesa conheça esse autor e alguns traços da cultura brasileira retratados em sua obra. 


\section{Os objetivos da pesquisa}

Como já dito anteriormente, a curiosidade e o gosto de Chico Buarque pelas palavras, assim como o seu expressivo talento em lidar com elas, formam o fio condutor desta investigação. É como base na exploração da criatividade lexical do autor que se pretende desenvolver uma análise, sob uma perspectiva descritiva, para avaliar até que ponto essa criatividade foi ou não recuperada pelas traduções.

Sendo assim, a principal proposta desta pesquisa é descrever e analisar algumas das escolhas feitas pelos tradutores dos romances de Chico Buarque. Este trabalho não se propõe a julgar as opções dos tradutores, mas levantar questões surgidas a partir das análises dessas escolhas. Pretende-se, também, comprovar a possibilidade de uso da base metodológica da Linguística de Corpus na análise de um corpus literário composto por obras originais e suas respectivas traduções e, consequentemente, promover um diálogo entre a Linguística de Corpus e a pesquisa na área de tradução.

Neste trabalho, propõe-se, ainda, investigar, a partir dos relatos orais, o nível de participação do autor nas traduções para a língua inglesa e como se deu a sua interação com os tradutores. Espera-se que seja possível compreender melhor, entre outros aspectos, as estratégias por eles utilizadas, o que autor e tradutores pensam sobre tradução e como ocorreu a colaboração de Chico Buarque com os tradutores para a língua inglesa de suas obras. 


\section{A estrutura da tese}

A partir desta introdução, o corpo da tese está organizado em 5 capítulos. O capítulo I versa sobre o escritor Chico Buarque, apresenta um breve resumo de sua trajetória literária e das obras literárias que fazem parte do corpus de estudo desta pesquisa e descreve - com base nas informações colhidas na entrevista realizada com autor - sua participação nas traduções de suas próprias obras para o inglês, assim como sua interlocução com seus tradutores. As opiniões do autor sobre tradução e o papel do tradutor também estão registradas neste capítulo.

O capítulo II é dedicado às vozes de Chico de Buarque em inglês, ou seja, às vozes dos tradutores, Bush, Landers e Entrekin. A abertura deste capítulo é feita a partir dos relatos de Liz Calder, co-fundadora da Bloomsbury e responsável pela publicação e difusão da obra de Chico Buarque na Inglaterra. Nele, comenta-se - com base nas entrevistas realizadas - sobre a interlocução desses sujeitos com o autor e sobre a participação do autor no processo tradutório. Os pontos de vista desses tradutores, no que diz respeito à tradução e às suas práticas, também são mencionados nesta parte do estudo.

O capítulo III apresenta o arcabouço teórico desta pesquisa. Nele são discutidos os conceitos teóricos relacionados à Linguística de Corpus como metodologia e abordagem aplicada à análise de um corpus literário. Os conceitos relacionados à convencionalidade são também abordados neste capítulo, pois são de especial relevância para as análises dos dados levantados a partir do uso de ferramentas computacionais. 
O capítulo IV descreve o corpus da pesquisa e todo o procedimento metodológico utilizado para sua investigação, baseado nos princípios da Linguística de Corpus.

O capítulo $\mathrm{V}$ consiste na análise do corpus de estudo realizada a partir da seleção das palavras-chave que fazem parte do campo semântico relacionado às partes do corpo humano. Neste capítulo, são apresentados os fatos revelados pela análise do corpus de estudo.

Finalizando o trabalho, são apresentadas as conclusões da pesquisa, confrontando os resultados alcançados com a hipótese anteriormente enunciada, assim como a comprovação da eficácia da Linguística de Corpus como abordagem e metodologia para investigação de um corpus literário. As informações colhidas a partir das entrevistas com a editora, o autor e os tradutores são também utilizadas na elaboração das considerações finais sobre este trabalho de pesquisa. 


\section{CAPÍTULO I}

\section{A trajetória literária de Chico Buarque e suas participações nas traduções de suas obras}

Neste capítulo, o objetivo não é o de apresentar uma biografia de Chico Buarque, tampouco fazer uma análise literária de suas obras - Estorvo, Benjamim e Budapeste - que constituem, juntamente com as suas respectivas traduções, o corpus de estudo desta pesquisa.

Pretende-se elucidar, após breve apresentação da trajetória literária do autor e dos resumos de cada uma de suas obras, alguns aspectos concernentes às traduções, tais como: as razões que levam o autor a participar das traduções de suas obras; como se deram sua participação nas traduções e sua interlocução com os tradutores dessas obras para o inglês: Peter Bush, Clifford Landers e Alison Entrekin; seu conceito de tradução; o que seria a tradução ideal na sua concepção. Vale ressaltar que o pensamento do autor sobre o papel do tradutor e sobre sua colaboração com as traduções também será comentado neste capítulo.

Existem várias publicações sobre o músico-escritor, Chico Buarque. Contudo, não há publicações - exceto algumas informações contidas em entrevistas - sobre sua condição de autor traduzido, tradutor, e em relação à tradução de suas obras a sua participação como: co-tradutor, revisor e colaborador. Portanto, as informações e considerações acerca de sua participação nas traduções de Estorvo, Benjamim e Budapeste, apresentadas 
neste capítulo, baseiam-se na entrevista inédita concedida a este pesquisador em setembro de 2008 , na qual se falou exclusivamente sobre esse tema.

Francisco Buarque de Hollanda nasceu em 19 de junho de 1944, na cidade do Rio de Janeiro, onde mora atualmente. É o quarto dos setes filhos da pianista amadora Maria Amélia Cesário Alvim e do sociólogo e historiador - de grande relevância na cultura brasileira - Sérgio Buarque de Hollanda ${ }^{11}$, autor, dentre outras obras, do livro Raízes do Brasil, escrito em 1936, considerado pelo crítico Antônio Candido "um clássico de nascença".

Chico Buarque é oriundo de uma família apaixonada pela música e pela literatura e, como afirma Silva (2004, p. 21), "Muito mais que a política [...], a música e a literatura foram as referências mais constantes e definidoras da casa dos Buarque de Holanda durante os anos de formação de Chico", esse ambiente familiar aliado ao seu interesse pela literatura contribuiu, sobremaneira, para sua formação de escritor.

A literatura serviu de instrumento de aproximação entre ele e seu pai, sendo uma espécie de passaporte para frequentar sem temor nem restrições a biblioteca paterna, local onde o escritor Sérgio Buarque passava grande parte de seu tempo. Seu pai, que mais tarde se tornara o primeiro leitor das criações de Chico Buarque, no início o estimulava a se dedicar à leitura: "ele me indicava desde clássicos, como Flaubert, até Celine, Camus e Sartre"12. Chico Buarque era um leitor voraz e desde jovem, entre quinze e dezesseis anos, já devorava as obras de seus escritores preferidos: "Chico atravessou com determinação de cupim toda uma prateleira de volumes em papel-bíblia da coleção francesa La Plêiade". (WERNECK, 2006, p. 24).

\footnotetext{
${ }^{11}$ Que adotou mais tarde a grafia "Holanda".

${ }^{12}$ Entrevista à Folha de S. Paulo em 1/9/1994.
} 
Além dos clássicos da literatura francesa, leu, pela tradução indireta do francês, os russos Kafka, Dostoievski e Tolstoi, até decidir-se pela leitura dessas obras, no original, tendo, inclusive se matriculado como ouvinte no curso de língua e literatura russa oferecido pelo professor Boris Schnaiderman, na FFLCH, da USP. Mas, seu aprendizado do idioma não foi muito além do alfabeto cirílico. Esse interesse trouxe outras impressões do compositor, chegou-se a relacioná-lo com questões ideológicas. Certa vez, perguntaram a ele se era comunista; ele respondeu que não; sua intenção era apenas literária: "Eu queria ler "Guerra e Paz" em russo". ${ }^{13}$

Esse leitor curioso e voraz dedicou-se também a autores brasileiros. Encantou-se pela escrita de Guimarães Rosa, principalmente por sua habilidade de criação lexical, característica marcante do estilo roseano na obra de Chico Buarque.

A vocação de Chico Buarque pela literatura surgiu na adolescência, antes de seu ingresso na Faculdade de Arquitetura de Urbanismos da Universidade de São Paulo, (FAU/USP), em 1963, onde permaneceu até 1966 e saiu sem concluir o curso. Naquela época, já dizia gostar da ideia de ser escritor e tinha a impressão que seria jornalista ou cronista. ${ }^{14}$ Aliás, essa vocação, que se manifestou na adolescência, já havia sido notada e registrada por escrito pela sua professora, Senhorita Tuttle, quando Chico Buarque, na ocasião com dez anos, morava com a família em Roma, onde seu pai ministrou aulas na condição de professor visitante na Universidade de Roma: "Quando o tempo passar e você estiver crescido", profetizou a mestra, "vou procurar contos e romances escritos por F.B. de Hollanda". (WERNECK, 2006, p.16)

\footnotetext{
${ }^{13}$ Entrevista inédita concedida a este pesquisador em 16 de setembro de 2008. A partir desta notação bibliográfica, todas as outras serão com a indicação Ent. 16/09/08.

${ }^{14}$ Entrevista à revista Playboy (1979).
} 
Em 1959, aos 15 anos, Francisco Buarque de Hollanda foi enviado pelos pais ao Colégio Cataguases, no interior de Minas Gerais, onde passou um semestre. ${ }^{15} \mathrm{E}$ lá, usando o pseudônimo "Bananal", escreveu para o jornal da escola "O Pirilampo".

Em 1961, já como aluno do Colégio Santa Cruz, criou e deu nome ao jornal estudantil Verbamidas, e nele publicou suas primeiras crônicas. O título, neologismo cunhado pelo autor, pode ser considerado um exercício de criatividade lexical do jovem aprendiz de escritor. Em 1966 ${ }^{16}$, publicou no Suplemento Literário de $O$ Estado de S. Paulo, o seu conto de estréia: "Ulisses", uma adaptação contemporânea de Odisséia, que, mais tarde, fez parte do seu primeiro songbook intitulado "A banda".

Esse suplemento apresentava também os manuscritos de suas primeiras canções e uma crônica de Carlos Drummond de Andrade sobre "A Banda". O texto não causou impacto e foi reconhecidamente chamado de "fraquinho" pelo próprio autor. Nesse ano, Chico Buarque mudou-se para o Rio de Janeiro e conheceu Marieta Severo Lins, com quem permaneceu casado por trinta anos, separando-se em 1997. O casal teve três filhas: Sílvia, em 1969, Helena, em 1970 e, Luísa, em 1975.

Em 1968, Chico publicou no jornal Última Hora, de São Paulo, o artigo "Nem Toda a Loucura é Genial, Nem toda a Lucidez é Velha." O artigo, de grande repercussão na época, era uma resposta às críticas recebidas dos tropicalistas. Nesse período, a maior parte da atenção e da produção artística

\footnotetext{
${ }^{15} \mathrm{Em} 1958$, quando cursava a terceira série do curso ginasial no Colégio Santa Cruz, em São Paulo, Chico Buarque e outros garotos de sua série, sob a influência do Professor Carlos Alberto de Sá Moreira, envolveram-se com o movimento religioso Ultramontanos, causando imensa preocupação aos seus pais, que decidiram enviá-lo para um internato em Cataguases. ${ }^{16} \mathrm{O}$ site do autor www.chicobuarque.com.br informa que essa publicação ocorreu nessa data. Já na obra "Chico Buarque" (SILVA, 2004, p. 115), a data da publicação do conto é 1965.
} 
de Chico Buarque estava voltada para a música. Contudo, explorando o seu potencial criativo, ele escreveu artigos esporádicos para jornais, dentre eles 0 Pasquim $^{17}$, iniciando também suas controvertidas incursões na dramaturgia em 1967, quando escreveu Roda Viva, a primeira de suas quatro peças. Em seguida, vieram: Calabar, em 1973, proibida pela censura e liberada em 1980, Gota d'Água, em 1975 e Ópera do Malandro, em 1978.

A tradução também fez parte do processo de criação literária de Chico Buarque. Em 1972, traduziu, em parceria com Rui Guerra, o musical "O Homem de La Mancha" e, em 1977, traduziu e adaptou as canções italianas de Luiz Enriquez e Sérgio Bardotti para o musical infantil "Os Saltimbancos".

Em 1974, publicou sua obra de estreia na literatura: a novela pecuária Fazenda Modelo: uma obra escrita por uma necessidade política e não literária. Silva (2004, p. 115-116) explica que: "a obra pretendia ser uma alegoria da modernização autoritária sob a ditadura militar". Na ocasião de sua publicação, a obra Fazenda Modelo foi relacionada à fábula Revolução dos Bichos (Animal Farm) de George Orwell, publicada em 1945.

Segundo Regina Zilberman (2004), ${ }^{18}$ a comparação entre as obras é legítima se considerarmos "a circunstância de que ambas as obras", produzidas em contextos sociais, históricos e políticos distintos, "atacavam o autoritarismo político, o planejamento estatal e a anulação de liberdades pessoais". Contudo, o alvo de "Fazenda Modelo" não era o regime de esquerda, soviético e sim o regime militar, brasileiro de direita, que dominava a nossa sociedade na década de 70 . Ainda que não haja um reconhecimento

\footnotetext{
${ }^{17}$ Um semanário carioca editado entre 1969 e 1991, reconhecido por seu papel de oposição ao regime militar.

${ }^{18}$ A propósito do assunto, cf. ZIBERMAN, Regina. "Não é conversa mole pra boi dormir. "Fazenda Modelo", novela pecuária, in "Chico Buarque do Brasil", Rinaldo de Fernandes, org. Rio de Janeiro: Garamond: Fundação Biblioteca Nacional, 2004, p. 363-370.
} 
explícito dessa intenção por parte de Chico Buarque, vale ressaltar que esse diálogo intertextual entre as duas obras é de fundamental importância para detectar o patrimônio cultural do autor, levando o leitor a perceber que o conteúdo literário é a recriação de universos revisitados por um olhar individual. Nesse caso, o fenômeno da intertextualidade apontado pela crítica contemporânea como uma das características marcantes da ficção moderna se verifica como um acréscimo de sentido qualitativo à produção e à pesquisa literária de Chico Buarque.

Em 1979, é editada a obra Chapeuzinho amarelo - com ilustrações de Ziraldo -, a primeira obra literária destinada ao público infantil de sua autoria. Chico Buarque escreveu o livro para sua filha Luísa, na forma de um grande poema. A obra Chapeuzinho amarelo, baseada no conto "Chapeuzinho Vermelho", de Charles Perrault, fala de uma garota medrosa que superou as suas limitações e transformou-se em uma pessoa corajosa. A coragem para enfrentar os temores é a mensagem dessa fábula.

Em 1981, lançou "A Bordo do Rui Barbosa", poema escrito entre 1963 e 64, ilustrado por Vallandro Keating, seu amigo desde 1963, quando se conheceram na FAU.

O início da década de 90 representou um divisor de águas na carreira literária de Chico Buarque. Após um período de 17 anos desde a publicação de Fazenda Modelo, ele começa a produzir suas obras literárias de mais relevância. A partir de então, ele publica os romances de sua maturidade: Estorvo (1991), vencedor do Prêmio Jabuti de Literatura, Benjamim (1995), Budapeste (2003), romance igualmente premiado. Em 2009, lançou o quarto romance dessa nova fase, o intitulado Leite derramado. 
As obras literárias de Chico Buarque já foram traduzidas para mais de vinte línguas. Em países como Noruega, Israel ou Sérvia, onde a música popular brasileira e Chico Buarque são menos conhecidos do que em outros países europeus como Itália, França, Espanha e Portugal, o compositor-autor é primeiramente reconhecido como um dos principais escritores da atualidade no Brasil e não como uma lenda viva da música popular brasileira. Nesses últimos países, as obras do autor já alcançaram marcas expressivas de vendagens, inicialmente impulsionadas pelo seu prestígio como compositor, admite Chico Buarque em entrevista concedida ao crítico literário Augusto Massi, em 1994, para a "Folha de São Paulo".

Com o objetivo de situar o leitor deste trabalho, talvez, ainda não familiarizado com as narrativas de Chico Buarque, apresenta-se, em seguida, os resumos - esboçados pelo pesquisador e, sem nenhum cunho literário ou valorativo - dos três romances que constituem o corpus de estudo desta pesquisa: Estorvo, Benjamim e Budapeste.

\subsection{Estorvo}

Estorvo, primeiro romance do compositor-escritor Chico Buarque vencedor do Prêmio Jabuti de Literatura em 1992 - é elogiado, principalmente, por sua habilidade com o uso das palavras. Segundo o crítico literário Roberto Schwartz, em comentário na orelha da referida obra, "[...] um livro brilhante, escrito com engenho e mão leve."

Já Salles (2004, p. 207), no ensaio intitulado "A Literatura do Estorvo", ressalta a opção do autor por um estilo de linguagem sem "malabarismos 
literários". Segundo ela, o autor se exprime através de um texto despojado que surpreende o leitor pelo "humor sutil, imagens fortes e nexos inesperados".

No romance, todas as personagens, inclusive o narrador-personagem, são identidades não nomeadas, não há nomes no texto, fato que, segundo Marcelo Pessoa, (2008, p. 7) "pode sugerir-nos a dinâmica da coletividade anônima presente nas cidades". A performance dessas personagens pode dizer respeito a todos nós, uma totalidade, ou uma singularidade: cada um de nós.

Narrado em primeira pessoa, Estorvo flutua o tempo todo entre a realidade e o sonho; o narrador-personagem cria para as situações reais, por ele vivenciadas, outras possibilidades de ocorrências dessas mesmas ações, ou seja, superposição de experiências vividas em dois planos paralelos: vivido e imaginado. Outra característica da obra é a narrativa não linear, com uma série de sequência de fatos, acaba retornando aos acontecimentos anteriormente narrados.

Estorvo, uma obra labiríntica e surpreendente, "de deixar o leitor de molho e de ressaca [...] por dias e dias depois da leitura" (LAJOLO, 1991), apresenta uma narrativa vivida por um protagonista andarilho, solitário, itinerante, errante, dominado pelo sentimento de perseguição, que parte à procura de sua irmã rica, sua mãe conservadora, sua ex-mulher e do sítio da família que havia sido ocupado por traficantes de drogas. Esse indivíduo, sem dinheiro e sem teto, transita entre dois mundos distintos: o da riqueza de sua família e da marginalidade. A odisseia do narrador-personagem, que é deflagrada a partir do momento que ele vislumbra pelo olho mágico o rosto de um homem não identificado, acaba sem respostas conclusivas sobre 0 
propósito e o destino de sua fuga insana. Estaria ele fugindo de si mesmo? "O romance não termina em xeque-mate e, portanto, prolonga-se ao infinito", como afirma Oliveira (2004, p. 101) ao comparar Estorvo com as melhores partidas de xadrez.

\subsection{Benjamim}

O segundo romance de Chico Buarque, Benjamim, assim como Estorvo, é reconhecido pelo talento como o autor burila as palavras. O estilo conciso e a "ausência de excessos de malabarismos literários"19 , já observados em Estorvo por comentadores desse romance, também se encontram presentes em Benjamim.

Ribeiro (2004, p. 63) ressalta que a obra é também marcada "pelo ritmo da frase, pela elaboração minuciosa, às vezes minimalista, de imagens e dos personagens". Ainda, no campo das reincidências, pode-se citar o fato de que os protagonistas de Estorvo e Benjamim continuam em permanente deslocamento e, ao mesmo tempo estáticos, pois não são capazes de alcançar algum objetivo em suas vidas. São indivíduos decadentes, atormentados, e deslocados socialmente, cujos percursos sinalizam para um desfecho trágico

Na obra Benjamim, Chico Buarque dá nome aos personagens e foge da narrativa em primeira pessoa. O romance é conduzido na terceira pessoa, mantendo a fusão de sonho e realidade. O real e o imaginário se confundem na narrativa, levando o protagonista a não conseguir diferenciar o passado do presente. $O$ enredo circular de Benjamim, se comparado ao romance anterior Estorvo, é "menos sufocante", nas palavras de Ribeiro (2004, p.65). O clima de

\footnotetext{
${ }^{19}$ A expressão é de Cecília Almeida Salles, no ensaio "A literatura do Estorvo", já citado; op. cit., p. 207
} 
tensão, opressão e obsessão contido no romance é consequência da estratégia narrativa utilizada pelo autor.

A narrativa cinematográfica, não linear e mostrada em flashback, tem início e fim com a cena dramática do fuzilamento do protagonista, Benjamim Zambraia, um ex-modelo fotográfico de meia idade, assombrado pela morte de seu amor de juventude Castana Beatriz, que morrera fuzilada por agentes da ditadura militar na década de 70, juntamente com o seu amante e ativista político, professor Douglas. Obcecado, Benjamim aproxima-se de Ariela Masé, uma bela e jovem corretora de imóveis, por acreditar que ela seja filha de Castana, e que, sob a ótica de Benjamim, é a duplicação da identidade de Castana. Circunstancialmente, Ariela acaba levando-o à morte trágica antecipada desde a abertura do livro.

Fazem parte do enredo outros personagens secundários: o doutor Campos Celeste, pai de Castana; o cabo de polícia Jeovan, namorado de Ariela; G. Gâmbalo, empresário da área de publicidade e marketing; Alyandro Sgaratti, indivíduo sem escrúpulos e candidato a um cargo político; Zorza, amigo de Ariela; dentre outros. Juntos, esses personagens compõem uma trama instigante que se desenvolve como um caleidoscópio diante dos olhos do leitor.

\subsection{Budapeste}

Budapeste, o terceiro romance de Chico Buarque pode ser considerado uma referência da sua maturidade literária, afirma André Albert, autor do ensaio 
intitulado "Narrador em amadurecimento"20. Bem recebido pelo público e pela crítica, o premiado Budapeste ${ }^{21}$ é, segundo Silva (2004, p.122), "vazado por um sarcasmo em baixo relevo quase do início ao fim, mas idenficá-lo não é fácil". Neste romance, assim como nos anteriores, Chico Buarque não dispensa os jogos de palavras, os protagonistas inquietos, deslocados e desconfortáveis com o mundo que os cerca, assim como o enredo circular.

O romance é caracterizado pela história do irônico narrador-protagonista José Costa, um escritor anônimo que, retornando de um congresso de ghostwriters $^{22}$, para acidentalmente em Budapeste (BUDAPESTE, 2003, p.6): "Fui dar em Budapeste graças a um pouso imprevisto, quando voava de Istambul a Frankfurt, com conexão para o Rio"23. Costa se encanta por aquela cidade, descrita por ele como sendo toda "amarela", embora pensasse que fosse "cinzenta"; pelo incompreensível húngaro - a "única língua do mundo que, segundo as más línguas, o diabo respeita." (BUDAPESTE, 2003, p. 6) - e, sobretudo, por Kriska, a sua professora de húngaro e amante. Essa parada imprevista nessa capital desencadeia os eventos que compõem a trama ambientada em dois espaços geográficos e culturais distintos: Rio de Janeiro e Budapeste.

No primeiro, José Costa mora com sua mulher Vanda, uma bem sucedida apresentadora de telejornal, e o filho do casal, Joaquinzinho, cujas relações familiares são marcadas pela falta de interlocução. No Rio, trabalha em sua própria agência em sociedade com Álvaro Cunha, seu amigo de

\footnotetext{
${ }^{20}$ Ensaio publicado na revista Bravo em dezembro de 2009, p. 44-53

21 Budapeste recebeu o Prêmio Passo Fundo Zaffari \& Bourbon de Literatura de melhor romance em língua portuguesa publicado entre 2003 e 2004, na 11 a Jornada Nacional de Literatura, bem como o Prêmio Jabuti de melhor Livro de Ficção de 2004.

${ }^{22}$ Autores anônimos de textos sob encomenda.

${ }^{23}$ Budapeste. São Paulo, Cia da Letras, 2003, p. 6.
} 
faculdade, escrevendo artigos, monografias, discursos para políticos, autobiografias para outras pessoas, como "O Ginógrafo", autobiografia erótica encomendada pelo empresário alemão Kaspar Krabbe, que se torna um bestseller. No segundo espaço, como Zsoze Kósta, convive com a amante Kriska, a pessoa que the ensina a língua magiar, e com Pisti, o filho de sua amante. $\mathrm{Na}$ obra Budapeste, trabalha no Clube de Belas Letras transcrevendo gravações das sessões literárias pretendendo assim dominar o idioma húngaro.

A partir desse episódio, a vida de Costa passa por uma reviravolta e a trama se alterna entre uma série de ambiguidades nele concentradas: José Costa e Zsoze Kósta; Rio de Janeiro e Budapeste; Vanda e Kriska; português e húngaro; fama e anonimato; autoria e não autoria, identidade e impostura, problemas e dicotomias experimentadas com maior intensidade pelo homem moderno. Esse jogo de duplicidades compõe o romance Budapeste, que Caetano Veloso ${ }^{24}$ chama de "um labirinto de espelhos", cuja saída não se traduz pelo jogo especular, mas sim pelos enigmas tramados nas "palavras, como os poemas".

Budapeste, assim como Estorvo e Benjamim, possui uma temática marcada pelos conflitos e buscas pessoais. Também comum aos três romances são os perfis dos protagonistas: homens que vivem acidentalmente, contudo, condenados a um inevitável destino catastrófico. Em Budapeste, o fluxo da narrativa é rápido, objetivo, sem "rebuscamentos afetados", próximo de uma linguagem cinematográfica. Essa característica marcante do autor permeia as três obras citadas e, segundo Pereira (2004, p.11), pode ser notada a partir "do uso breve dos títulos como forma de sintetizar, de consolidar nos

${ }^{24}$ Resenha crítica sobre a obra publicada no jornal O Globo. 
olhos do leitor as portas a serem abertas." Tais reincidências presentes nos romances de Chico Buarque estão longe de serem consideradas limitações, pois, como bem observa Silva (2004, p.118), elas são "criadas a partir de dinâmicas próprias e enredos distintos", e "vão delineando não apenas um estilo de escrita, mas dando forma a uma representação problemática do país e da cena contemporânea."

Vale ainda observar os comentários de André Albert ${ }^{25}$ que, analisando os três primeiros romances de Buarque, aponta um "progressivo refinamento da linguagem e da construção narrativa", fazendo-o qualificar Budapeste como o marco da maturidade literária desse autor. A complexidade da obra literária de Chico Buarque, aliás, não reside na linguagem utilizada, mas na comentada forma de narrativa adotada por ele. A incursão aos labirintos dos romances da maturidade de Chico Buarque, segundo Silva (2004, p. 111), "[...] não é o caminho da facilidade, sem percalços, sem buracos ou desvios abruptos." Mas, destinada a um viajante-leitor disposto e preparado para encarar desafios discursivos e escriturais propostos pelo autor em suas obras.

\subsection{Chico Buarque e tradução}

Chico Buarque é um curioso pela palavra, pela linguagem, como revelou em uma entrevista concedida a Josué Machado. ${ }^{26} \mathrm{~A}$ sua devoção às palavras e seu talento para com elas são exemplos marcantes de sua trajetória, seja como músico-letrista ou escritor. Tais características, aliadas ao conhecimento da língua italiana aprendida na Itália quando lá morou na sua infância, do inglês falado na mesma época ao frequentar a escola americana em Roma, do

\footnotetext{
${ }^{25}$ Ensaio publicado na revista Bravo, publicada em dezembro de 2009, pp. 44-53

${ }^{26}$ Entrevista publicada na revista Língua Portuguesa, Ano I, número 8, 2006.
} 
francês estudado no curso ginasial, na cidade de São Paulo e do espanhol vivenciado em suas viagens pela América Latina, habilitam-no a colaborar com os tradutores de suas obras nessas línguas.

Referindo-se ao grau de participação nas traduções dos três romances anteriormente citados, Chico Buarque declarou que sua proficiência no idioma inglês não lhe permite "ser partícipe" das traduções, acreditando ser o seu conhecimento desse idioma suficiente apenas para "apontar equívocos", "uns lapsos ou enganos na compreensão do texto original". Chico Buarque afirma que, em inglês ou em qualquer outra língua, não poderia apontar uma "solução", apenas chamar a atenção do tradutor para o "erro", dizendo: "olha, nisto aqui eu não quis dizer tal coisa; eu quis dizer outra coisa". Segundo o autor, esse tipo de evento ocorre, às vezes, com as traduções de expressões idiomáticas.

$\mathrm{Na}$ opinião de Chico Buarque, a sua participação na tradução deve ocorrer para evitar esses "erros": "eu tenho que cuidar para que não aconteçam esses equívocos que eu te falei, equívocos de compreensão". Com respeito ao "domínio do tom, das nuances" de linguagem, o autor afirma não tê-lo em nenhuma língua estrangeira, daí a sua dificuldade em julgar o tom da narrativa na língua estrangeira.

Como o autor já afirmou em várias entrevistas, ao se referir a sua formação de músico e à influência da música em sua literatura, ele busca "a musicalidade", a "sonoridade da frase", acreditando, dessa forma, que a sua literatura "tenha uma musicalidade peculiar que é muito difícil de traduzir. [...] quase impossível" e que, portanto, não tem como exigir isso do tradutor. 
A participação efetiva de Chico Buarque no processo da tradução resultou, inclusive, em mudanças e acréscimos que não existiam na obra original: "O que aconteceu foi, na tradução, eu ter uma ideia nova e eu mudar". Conforme seu relato, a reação do tradutor foi imediata: "mas não é isso que está em português!" Nesses casos, predominou a intenção do autor mesmo em se tratando da tradução: "eu sei, mas eu prefiro assim, [...] eu quero mudar." Buarque afirma que o contrário certamente ocorrera, ou seja, a solução apresentada pelo tradutor não correspondia à sua intenção original, mas foi aceita por não haver, na língua de chegada, uma tradução literal: "Era impossível traduzir fielmente."

Ainda sobre o grau de participação nas traduções de suas obras literárias, cabe registrar, embora esteja fora do escopo desta pesquisa, que Chico Buarque aparece como co-autor da tradução de Estorvo para o francês. Segundo o autor, "fizeram essa gentileza". De acordo com o relato de Buarque, a participação dele nessa tradução se deu parcialmente in loco, quando passou uma temporada em Paris; as conversas com a tradutora aconteciam diariamente.

Considera-se importante salientar o fato de que, além de sua familiaridade com o idioma francês, a proximidade entre autor e a tradutora resultou em uma tradução a quatro mãos.

Segundo o autor, "Depois de muita conversa" sobre a tradução de uma determinada palavra, a dupla chegava a uma "terceira palavra", que não era nem a primeira escolha lexical do tradutor nem outra sugerida pelo autor, porque a palavra não soava natural no idioma francês. Permanecia "uma terceira palavra" apresentada pelo autor e acatada pelo tradutor: "De repente, 
por que não tal palavra?", sugeria o autor. "Porque essa palavra existe, mas não é francês, isso não vai funcionar dentro da frase", responde o tradutor. "Por que não tal palavra?", volta a opinar o autor. "Ah, essa palavra pode ser", concorda o tradutor. Assim, as negociações se passavam, conforme relembra Chico Buarque.

Conforme mencionado anteriormente, o autor não reconhece sua condição de participante, nas traduções de suas obras, por julgar que o seu nível de proficiência em outras línguas não seja suficiente para tal. Contudo, foi nomeado co-tradutor, como no caso da tradução para o francês mencionada no parágrafo anterior. Quando questionado sobre a possibilidade de se tornar tradutor de si mesmo, assegura que isso não é possível: "Não tem como. Não tenho conhecimento para isso e imagino que loucura que é." Chico Buarque afirma já ter feito versão de letras de música para o francês e considera essa tarefa muito difícil.

Os diálogos com os tradutores Peter Bush (Estorvo), Clifford Landers (Benjamim) e Alison Entrekin (Budapeste), ocorreram de formas diferentes. A maior parte da correspondência com Bush ocorreu, via fax e, pessoalmente. Chico Buarque relata que o trabalho de tradução de Estorvo foi bastante difícil. Por ocasião de sua ida a Londres, a convite da editora Bloomsbury, autor e tradutor entraram pela noite "discutindo minúcias da tradução" no hotel onde Chico Buarque estava hospedado. Os contatos com Landers se deram via fax e também por telefone.

Já com Alison, a comunicação foi mais fácil devido ao uso da internet. Nas palavras do músico-escritor, o advento da internet facilitou também o seu trabalho de acompanhamento das traduções. Segundo ele, acompanhar "passo 
a passo o que está sendo traduzido" é a melhor opção, porque "há erros de interpretação que vão se acomodando, fato que "não aconteceria lá adiante, se fossem corrigidos numa primeira parte."

Quando o assunto é a fidelidade do tradutor, Chico Buarque reconhece a complexidade da questão: "Isso é tão difícil, sabe. Eu sei das dificuldades. Eu mesmo já traduzi - não literatura - já traduzi letra de música, então, eu sei o que é." Ele afirma que as discussões com os tradutores acerca da tradução de uma palavra ou frase chegam a gerar "desavenças", "chegam a um ponto de quase ruptura". Às vezes, o autor insiste em uma tradução literal como forma de resgate de sua intenção original: "Mas o que eu quero dizer não é isso que se escreveu. Eu quero dizer é isso aqui: tal, tal, tal", mas o tradutor refuta a opinião do autor: "perfeito, está muito bom, mas não é inglês". Então, o autor acaba reconhecendo que a tradução literal seria mais "fiel", mas muitas vezes não "funciona na língua" de chegada.

Certa vez, relata Chico Buarque, ele teve uma discussão com o tradutor de Estorvo, Peter Bush, sobre a tradução da palavra "pudor" no seguinte trecho: "Mas as pessoas dos prédios modernos também têm pudor de aparecer no terraço." Como Bush não falava português, o diálogo era em inglês. Chico Buarque então explicou ao tradutor que a palavra shame, inicialmente, sugerida por Bush - cuja tradução para o português era "vergonha" -, não tinha o mesmo significado que "pudor". Insatisfeito com a escolha lexical de Bush, Buarque foi ao dicionário e encontrou uma palavra em inglês cuja tradução para o português seria "pudicícia". Quando perguntou ao tradutor "por que isso não?" o tradutor riu, pois a escolha de Chico Buarque não soava natural no idioma inglês. 
A versão final acabou privilegiando a convencionalidade na língua de chegada: "But the people in the modern buildings also shy away from their terraces." A atitude de Bush que, naquele momento, deixara o autor bastante aborrecido, foi posteriormente relatada na entrevista como "coisas engraçadas na tradução".

Sobre o estranhamento que a tradução pode, às vezes, causar ao leitor da língua de chegada, Chico Buarque cita o diálogo com a tradutora de Estorvo para o alemão: "Olha, Karen, eu acho que Estorvo tem que parecer que foi mal traduzido" porque "esse estranhamento existe no original." Ele relaciona a opção do tradutor por uma estratégia de fluência ao fato de que "nenhum tradutor quer dar a impressão de que fez mal o seu trabalho", ressaltando outra razão que leva o tradutor a adotar tal estratégia: "É difícil [...] o tradutor convencer o seu editor ou o seu público leitor de que aquela é a tradução mais fiel do livro."

Na opinião de Chico Buarque, o estranhamento contido no texto original deve ser mantido na tradução. Ainda que o tradutor esteja sujeito a um possível julgamento pelo leitor da língua de chegada: "Às vezes, o estranhamento é original; esse estranhamento tem que passar para a tradução. O tradutor está correndo o risco de ter seu trabalho criticado, mas acontece isso, como vai fazer?"

No que concerne ao papel do tradutor, Chico Buarque o considera um "parceiro", um "intermediário" entre as duas línguas e culturas envolvidas no processo tradutório. Contudo, confessa não gostar quando percebe um desejo exagerado de participação autoral do tradutor, deixando entender que a visibilidade intencional do tradutor, às vezes, o incomoda. Segundo Chico 
"Agora, já me aconteceu de eu perceber que há um desejo de parceria, talvez até inconsciente, do tradutor, até porque gostou e quer entrar naquilo e, já que não pode traduzir uma determinada frase fielmente, ele quer alguma coisa naquele lugar para substituir. Então, é interessante, mas, às vezes, ele pode se exceder um pouquinho, aí eu procuro conter."

Chico Buarque relata ainda que a sua parceria com a tradutora de Budapeste se deu de forma lúdica: "Eu me diverti muito com a Alison". O autor conta que, diante da impossibilidade da tradução literal de "jogos de palavras", ele "dava a chave do jogo" à tradutora chamando a sua atenção para a presença de uma determinada "aliteração", de um "quase anagrama" e explicitava a sua intenção com relação ao uso de determinadas palavras e estruturas sintáticas: "Eu quis fazer esse jogo" e passava a responsabilidade das escolhas para tradutora: "Agora a bola está contigo. Como é que se faz isso em inglês?" Buarque afirma que, "às vezes, dava um chute e passava longe; às vezes, até podia ajudar" e finaliza dizendo que, em uma situação como essa, ele deseja que "o tradutor seja um parceiro."

Pode-se dizer que essa "parceria" tem início ainda durante a criação do original. Buarque declara ter consciência, atualmente, que sua obra será traduzida para outros idiomas e durante a escrita essa preocupação, às vezes, passa por sua cabeça: "Isso, para ser traduzido, vai dar trabalho". Mas, se não custar nada, na hora, trocar uma coisa ou outra, pensando nisso, eu não me incomodo. Outras vezes - eu sei, porque eu estou trabalhando com isso agora $^{27}$ - são coisas que eu digo [...] tem que ser assim, vai se encontrar um jeito, mas eu sei que vai haver problemas.

${ }^{27}$ Referindo-se ao seu mais novo romance Leite Derramado publicado em 2009 ainda sem tradução para o inglês. 
Falando sobre estratégias de tradução, Chico Buarque, na posição de leitor e autor, afirma que o modelo ideal é aquele que transporta o leitor até sua obra, ou seja, uma tradução voltada para a língua e culturas de chegada. Buarque acredita que existe por parte dos tradutores em geral, não de seus tradutores em particular, uma tendência a crer que o leitor não tem o desejo de ser transportado para a cultura de partida. Em sua opinião, o tradutor que domestica o original e se propõe a fazer uma tradução facilitadora "por comodismo, ou por preguiça" está sendo infiel tanto ao autor quanto ao leitor da tradução: "quando o tradutor procura facilitar a obra para ficar mais acessível ao leitor está traindo os dois."

Nas palavras de Chico Buarque, a tradução perfeita é aquela em que tradutor não "falseasse nada", "não procurasse domesticar" e mesmo assim fosse capaz de causar no leitor "a impressão de que está originalmente escrito naquela língua." Daí, conclui o autor, o tradutor teria conseguido "a perfeição do trabalho". Contudo, acha que tal realização é "inatingível". A tradução ideal, reitera o autor, seria a que mantivesse certas características do original como o estranhamento, as marcas culturais e "que o leitor lesse na sua casa, nos Estados Unidos, história de orixás, de carnaval sem achar que está lendo um livro traduzido," a tradução "seria tão bem feita que ele se sentiria parte daquele universo, parte daquela cultura." 
CAPÍTULO II

\section{As vozes de Chico Buarque em inglês: Bush, Landers e Entrekin}

\subsection{Peter Bush}

O britânico Peter Bush ${ }^{28}$ foi o primeiro tradutor de língua inglesa a ter 0 romance de estreia de Chico Buarque, Estorvo, publicado. Conforme relatou em entrevista concedida a este pesquisador em junho de 2008, ele começou sua atuação como tradutor literário de tempo integral no início da década de 90.

Desejando expandir o escopo de seu trabalho enviou a Liz Calder, cofundadora da editora britânica Bloomsbury, a tradução do livro Beltenebros do escritor espanhol, Antonio Muñoz Molina. Nessa ocasião, entre uma e outra xícara de chá, Bush recebeu de Liz Calder o convite para traduzir Estorvo: "Eu fui ao encontro dela. E estava muito claro; ela não estava interessada na tradução de um livro de Muñoz Molina."29 E segundo seu relato, na segunda xícara de chá, Liz Calder ofereceu-Ihe uma diferente empreitada: "este é o primeiro romance escrito por Chico Buarque e estamos procurando um tradutor

\footnotetext{
${ }^{28}$ Peter Bush, ganhador de vários prêmios de tradução literária, mora atualmente em Barcelona onde trabalha como tradutor literário. Tem sido atuante na defesa dos direitos dos tradutores literários como membro da International Translation Federation Bush estudou espanhol e francês na Universidade de Cambridge. Foi professor de tradução literária na Universidade East Anglia, onde dirigiu o British Center for Literary Translation e trabalhou com consultor para o Channel Four, da televisão britânica, onde dirigiu o programa sobre artes, Rear Window. Peter Bush traduziu Juan the Landless, de Juan Goytisolo, Havana Fever, de Leonardo Padura, dentre os outros mais de cinquenta livros.

29 "And it was quite obvious; she was not interested in a translation of a book by Muñoz Molina"
} 
para este livro. Você estaria interessado?"30 Embora soubesse português e conhecesse o músico Chico Buarque, Bush nunca havia traduzido literatura de língua portuguesa e nem mesmo o conhecia como escritor. Após a leitura do livro, ele aceitou o desafio de uma nova tradução proposto por Liz Calder, pois, aliás, Estorvo fora traduzido por um norte-americano, e o trabalho recusado por Chico Buarque e Luiz Schwartz, editor da Companhia das Letras. Nas palavras de Bush, a primeira tradução - correta em termos de equivalência - havia falhado ao captar a musicalidade do original: "a tradução é fiel, eu diria engessada. Ela, mais correta em termos de equivalência, mas não capta a música do original”31 Em sua opinião, a primeira tradução foi rejeitada por não respeitar o estilo do original, acrescentando informações e promovendo mudanças do registro de linguagem, do informal para o formal em inglês, e da forma narrativa, do discurso seccionado para o fluente em inglês:

Esta é a razão pela qual a primeira tradução foi rejeitada, porque a
tradução foi uma tradução que tentou ignorar a singularidade do
estilo. Ela tinha muito material explicativo, ela condensou coisas em
um estilo inglês mais formal do que é o estilo do original em
português, que é muito fragmentado. ${ }^{32}$

Considerando as informações de Bush sobre a primeira tradução de ‘Estorvo", pode-se entender que a estratégia adotada pelo tradutor não recria o estilo de narrativa do original; pois como afirma Pessoa (2008, p.8): "a interrupção é a tônica predominante do discurso buarqueano em Estorvo.

Dessa vez, comentou Bush, tanto a editora Bloomsbury quanto Buarque buscavam um profissional, leitor, atento às peculiaridades estilísticas do

\footnotetext{
30 "this is the first novel written by Chico Buarque, Estorvo, and we are looking for a translator of this book. Would you be interested?"

${ }^{31}$ "the translation is loyal, I would say wooden. It's more correct in terms of equivalence, but it doesn't capture the music of the original."

32 "This is the reason why the first translation was rejected, because the translation was a translation that tried to ignore the uniqueness of the style. It put in lots of explanatory material, it joined up things in a more formal English way than it's the case in the original Portuguese, which is very choppy."
} 
original. Bush traduziu as primeiras quarenta páginas, enviou-as a Liz Calder, que remeteu tal amostra ao autor. Como informa Bush, Buarque submeteu esse trecho da tradução à leitura de seu editor brasileiro, Luiz Schwartz e do escritor Rubem Fonseca. Segundo Bush, eles valorizaram o fato de sua tradução ter assimilado o tom do original: "Basicamente, eles gostaram de minha tradução, eles acharam que minha tradução tinha meio que captado mais ou menos o tom de Estorvo." ${ }^{33}$

Nessa época, Bush trabalhava na Middlesex University como professor de tradução literária e participava como consultor do programa de televisão sobre artes internacionais, Rear Window, exibido pelo Canal 4 da televisão britânica. Nessa condição Bush propõe a realização de um documentário sobre Chico Buarque, se deslocando até o Rio de Janeiro para esse trabalho jornalístico que se tornou, então, parte da pesquisa para tradução de Estorvo, permitindo-Ihe, inclusive, manter um diálogo mais próximo com Chico Buarque.

Como relatou Bush, na entrevista concedida a este pesquisador, as filmagens realizadas em locais parecidos com a ambientação do romance, as perguntas aprofundadas sobre o texto original e as conversas com o autor em sua própria casa foram uma forma de diálogo e intercâmbio muito interessantes. O outro lado desse diálogo, salientado por Bush, estava relacionado às expectativas do autor e da editora com relação à nova tradução a ser por ele realizada; eles queriam uma tradução que compreendesse o tom, e o humor do romance original.

Outro aspecto foi o desejo de Chico e da Bloomsbury de conseguirem uma tradução realmente muito boa, uma tradução precisa e também uma

\footnotetext{
33 "Basically, they liked my translation, they thought my translation had kind of captured more or less the tone of Estorvo."
} 
tradução que fosse uma tradução musical [...] para captar o humor do romance - ele é um romance introspectivo..$^{34}$

Parte dos diálogos com o autor ocorreu também na Inglaterra. Durante uma das estadas de Buarque em Londres, o tradutor se recorda da participação de Liz Calder e de Nigel Newton, fundador e diretor executivo da editora Bloomsbury, nas conversas sobre a sua tradução: "Então todos estavam meio que interessados em meio que ler a tradução e dar algum tipo de contribuição". ${ }^{35}$ Liz Calder, conforme relata Bush, costumava passar diariamente pelo hotel onde Buarque estava hospedado e participar das discussões sobre a tradução.

Ao final desse processo, criou-se um impasse a respeito do título do livro. Bush não gostou do título Turbulence porque estava semanticamente associado à aviação: "turbulência é algo que as pessoas pensam em termos de aviões" ${ }^{\prime 36}$, ele gostaria que o título da obra fosse Turmoil porque traduzia melhor o espírito do livro. Ambos, Buarque e Calder, concordavam com Bush, mas, por razões comerciais, prevaleceu a opinião do editor americano: "mas os americanos não permitiriam, de forma alguma, que fosse outro título se não Turbulence. Eles disseram que seria impossível vender um livro nos Estados Unidos que tivesse Turmoil como título. ${ }^{37}$ Portanto, o título do livro foi algo imposto. Verifica-se um importante componente ideológico-cultural a conduzir as escolhas e respostas editoriais que, mesmo influenciando os "destinos" de

\footnotetext{
34 "Another aspect of it was the desire of Chico and Bloomsbury to get [...] kind of a really good translation, an accurate translation and also a translation that was a musical translation [...] to capture the mood of the novel - it is a very moody novel."

35 "So all the people were kind of interested in kind of reading the translation and having some kind of input."

36 "Turbulence is something that people think about in terms of airplanes."

37 "but the Americans absolutely wouldn't let set any other title but Turbulence. They said that it would be impossible to sell a book in the United States that had the title Turmoir".
} 
uma produção literária, privilegiam o contexto cultural de recepção da obra traduzida.

A troca de correspondências entre autor e tradutor foi feita por fax, nas palavras de Bush: a dialogue by fax. Buarque esteve na Europa para trabalhar com os tradutores de Estorvo para o francês, italiano e espanhol, passando, nessa época, uma semana em Londres. Na oportunidade, quando a tradução já se encontrava em um estágio avançado, Bush relata que trabalharam diariamente por quase uma semana: "Nos reunimos todos os dias por cinco dias e conversamos sobre cada frase da tradução; passamos por cada uma." ${ }^{38}$

Bush diria que o principal interesse de Buarque em seu diálogo com ele era tentar levar o inglês o mais próximo possível dos ritmos e sotaques brasileiros. O objetivo central da conversa entre eles era produzir a melhor tradução possível: "Era um diálogo sobre o que poderia ser a melhor tradução" ${ }^{39}$ e, apesar do elevado nível de proficiência linguística do autor, "porque Chico tem um inglês muito bom." ${ }^{40}$-, não era sempre que Bush acatava as suas interferências: "mas algumas vezes eu não concordava com sua sugestão" ${ }^{41}$ Às vezes, Buarque queria usar palavras que pinçava de um dicionário, mas Bush as considerava inadequadas, e dizendo-Ihe que embora as palavras existissem, não eram adequadas ao contexto: "não podemos usar esta palavra em inglês porque pareceria deslocada, pareceria engraçado, de

\footnotetext{
38 "We met everyday for five days and talked about every sentence of the translation; we went through it."

39 "It was a dialogue about what could be the best translation"

40 "because Chico has very good English"

41 "but sometimes I didn't agree with his suggestions."
} 
uma forma errada, pareceria ridículo; não podemos usar esta palavra; sim, ela existe, mas não podemos usá-la aqui.."22

No geral, as discussões não eram necessariamente a respeito do significado, ou seja, sobre a busca de uma equivalência perfeita, mas sobre o tom e o ritmo da narrativa: "não era necessariamente sobre um significado direto; era sobre nuances e era sobre ritmo." ${ }^{43}$ Para Bush, era essencial manter na tradução o ritmo do original, já desde as primeiras páginas do livro: "Eu acho que basta olhar nas páginas de abertura do livro" [...] "é uma questão de ritmo" [...] "e então é muito importante manter este tipo de ritmo" ${ }^{44}$ Segundo Bush, o deslocamento permanente do protagonista devia ser captado pela tradução: "o personagem não sabe exatamente onde ele está [...] o homem está em constante movimento, e o tradutor tem meio que captar este sentido de movimentação constante que faz parte do romance." ${ }^{45}$

O tradutor corrobora ainda a reputação de Buarque como "um obsessivo torneador de palavras" 46 , ao falar do zelo que o autor tem com relação a sua escrita: "Seu romance é escrito, com muito, muito cuidado; é muito poético." Comparando Chico Buarque a Flaubert, enfatiza a busca do autor pela melhor escolha lexical, frasal e pela cuidadosa estruturação ou desestruturação dos parágrafos e dos capítulos:

\footnotetext{
42 "we can't use that word in English because it would seem out of place, it would seem funny, in a wrong kind of way, it would seem ridiculous; we can't use that word; yes, it exists, but we can't use it here."

${ }_{43}$ "it wasn't really necessarily about straightforward meaning; it was about nuances and it was about rhythm."

44 "I think if you look just at the opening pages of the book [...] it's an issue of rhythm [...] and so it's very important to maintain the kind of rhythm".

45 "the character doesn't know quite where he is [...] the man is constantly on the move, and the translation has to kind of capture this sense of constant movement that he is involved in".

${ }^{46}$ Expressão usada por Regina Zappa em seu ensaio intitulado "Vertigem" in: Chico Buarque do Brasil, FERNANDES, Rinaldo, Rio de Janeiro: Garamond, 2004.

47 "His novel is very, very carefully written; it's very poetic"
} 
Ele é um sujeito à procura da palavra cuidadosamente escolhida, da sentença cuidadosamente estruturada, do parágrafo cuidadosamente estruturado ou do parágrafo cuidadosamente desestruturado ou do capítulo cuidadosamente estruturado. ${ }^{48}$

Bush complementa seus comentários sobre o estilo do autor lembrando que Chico Buarque é um escritor "excêntrico" - no sentido de configurar o aspecto excepcional, incomum e surpreendente da obra do autor -, que comunica suas ideias e impressões por meio de uma linguagem cuidadosamente escolhida:

Chico é um poeta excêntrico [...]. Ele é este sujeito excêntrico que está tentando comunicar algo, uma atmosfera, um humor, o sentido da falta de comunicação verdadeira entre as pessoas, a dificuldade de se conviver com diferentes linguagens ou com diferentes bairros da cidade. Ele está tentando comunicar essas coisas por uma linguagem que é escolhida com muito cuidado." ${ }^{49}$

O conhecido apego de Chico de Buarque à sua criação artística, musical e literária, chegando às vezes ao ciúme, é relatado por Bush no que concerne ao seu primeiro romance: "É seu primeiro romance, quero dizer, ele tinha muito ciúme dele; era como um filho que ele não queria deixar partir”. ${ }^{50}$ Esse aferro a sua obra aparece também no universo ficcional do autor. O sentimento do personagem José Costa, de Budapeste, ao perder a posse absoluta de sua obra é assim descrito: "a revisão de um livro era para mim um tempo de extremo apego" [...] "abrir mão de um livro pronto e acabado era sempre doloroso".

Ainda sobre a participação autoral de Chico Buarque na tradução de Estorvo, Bush ratifica que o autor, durante o processo de revisão da tradução,

\footnotetext{
48 "He's somebody who's looking for the carefully chosen word, the carefully modulated sentence, the carefully modulated paragraph or the carefully modulated non-paragraphs or the carefully modulated kind of chapter."

49 "Chico is an eccentric poet [...]. He's this eccentric somebody who is trying to communicate something, an atmosphere, a mood, the sense of the lack of real communication between people, the difficulty of living in different languages or in different districts of the city. He's trying to communicate these things through a language that is very carefully chosen."

50 "It's his first novel, I mean, he was very jealous of it; it was like a child and he didn't want to let go of it.
} 
ao perceber que a tradução na sua visão parecia não estar boa, decidiu fazer alterações no original, modificando, assim, a tradução baseada na obra publicada: "Eu gostaria de trocar isso no português, no original agora. Então, vamos [...] podemos fazer isto?"

Observa-se, em consequência, que a atuação do tradutor e, principalmente, o envolvimento da editora Bloomsbury na tradução de Estorvo, não são comuns nas traduções de obras de outros autores. Geralmente, o tradutor envia a tradução e a editora possui um revisor que faz alterações e sugestões. Como exemplo, Bush menciona a tradução de um livro do escritor português, Tavares, que não se envolveu em nada com a tradução, sob a alegação de estar muito ocupado com a produção de seu próximo romance.

Quando indagado sobre a estratégia de tradução por ele utilizada na tradução de Estorvo, Bush rejeita claramente a dicotomia source $x$ target. $^{52} \mathrm{Eu}$ realmente não gosto de usar este tipo de palavras como "source" ou "target. "53 Sobre a sua tradução dessa obra, ele afirma ter se esforçado para recriar na língua de chegada aquilo que o autor criou na língua de partida. Com a sua tradução, Bush espera que os leitores captem o sentido da poesia criado pelo autor e o clima criado na mente do protagonista anônimo.

É uma tradução que faz melhor de si, tenta da melhor forma recriar em inglês o que Chico fez em português brasileiro. Então, em termos de pontuação, em termos da estrutura da sentença, em termos de vocabulário, ela se mantém o mais próximo possível daquilo que Chico está tentando fazer [...]. O que espero é, quando os leitores lerem a tradução, que eles tenham o sentido da poesia que Chico criou e da atmosfera que ele criou na mente desse personagem, ${ }^{, 54}$.

\footnotetext{
51 "I'd really like to change that in Brazilian, in the original now. So let's[ ...] can we do this?".

${ }^{52} \mathrm{O}$ tradutor se refere às traduções voltadas para língua e cultura de partida ("source oriented") e às traduções voltadas para a língua e cultura de chegada, ou seja, língua e cultura alvo ("target oriented").

53 "I really don't like the use of this kind of words like source or target".

54 "It's a translation that does its best, tries its best to recreate in English what Chico has done with Brazilian Portuguese. So, in terms of punctuation, in terms of sentence structure, in terms of vocabulary it keeps as close as it possibly can to what Chico has been trying to do [...]. What
} 
No caso específico da tradução de Estorvo, o seu objetivo era criar e priorizar em inglês, a narrativa fragmentada do texto original. A tradução deveria incomodar o leitor linguisticamente. Ao falar sobre como deve ser o trabalho de uma tradução literária, Bush cita a fala um autor espanhol, que compara o trabalho literário a uma aventura desafiante para o leitor: "o trabalho literário é como uma aventura, ele deve ser algo que perturbe o leitor e que perturbe a língua." 55

Bush valoriza cada palavra do texto original, o que não significa, na sua concepção, traduzir palavra por palavra, mas garantir, de forma consciente e intencional, que o impacto gerado por cada palavra no original esteja também presente na tradução:

Quando estou traduzindo, estou sempre consciente de querer fazer valer cada palavra. Mas fazer valer cada palavra que está no texto original não significa que você esteja traduzindo palavra por palavra; significa que você quer garantir que o impacto de cada palavra do original esteja lá na sua tradução. ${ }^{56}$

Para Bush, não é papel do tradutor se importar com a opinião do leitor.

Ele afirma não pensar no receptor durante a fase de execução da tradução. A preocupação com o leitor ocorre apenas na fase da edição da tradução. Ele mencionou na referida entrevista que sequer tem conhecimento do público leitor de literatura traduzida na Inglaterra.

Eu acho que um tradutor, quando está traduzindo um romance, está criando uma leitura e uma interpretação do romance [...] ele está realmente traduzindo para aquele leitor que ele próprio é como tradutor naquela operação de traduzir. [...]. Eu acho que, o que o tradutor deve fazer, é não pensar, bem, algumas pessoas não gostariam disto ou algumas pessoas ficariam descontentes com isso ou com aquilo. Não é função do tradutor, pensar sobre isso [...].

I hope is that when readers read it they have a sense of the poetry that Chico has created and the atmosphere that he's created within this man's mind".

55 "the literary work is like an adventure, it must be something that disturbs the reader and disturbs the language".

56 "When I'm translating, I'm always conscious of wanting to count for every word. But to count for every word that's in the original text doesn't mean that you're translating word for word; it means that you want to insure that the impact of every word in the original is there in your translation". 
Quando estou fazendo a edição tenho alguma noção de como os leitores pensariam sobre isso. ${ }^{57}$

O seu principal objetivo como tradutor é recriar em inglês o estilo do original: "Quando eu tento traduzir qualquer livro, a intenção é criar em inglês as ressonâncias contidas no estilo do original e isto para mim é a prioridade." 58 De acordo com a sua concepção, é obrigação do tradutor tentar recriar na língua de chegada o estilo único do autor: "A writer has created something that has a unique style and the translator must try to recreate that in his language." Consequentemente, a tradução correta, para esse profissional, é aquela que consegue captar o ritmo do original: "Eu acho que a tradução correta é a tradução que capta o ritmo original do livro". 59

Bush considera difícil avaliar o impacto que as teorias sobre tradução têm em sua prática tradutória. Afirma que as leituras sobre tradução e a sua história o tornam consciente de alguns aspectos do processo de tradução. Para ele, o tradutor-escritor é influenciado por muitas teorias, não apenas pelas teorias de tradução; essas representam uma pequena parte desse universo tradutório. No seu caso, por exemplo, as leituras de obras literárias norteamericanas e britânicas exercem uma influência maior sobre a tradução que ele esteja realizando do que essas teorias: "Quero dizer, por exemplo, que minhas traduções talvez sejam mais influenciadas pelas obras das literaturas

\footnotetext{
57 "I think that a translator, when he's translating a novel, he's creating a reading and interpretation of the novel [...]. He's really translating for that reader that he himself is as a translator in that operation of translating. [... ]. I think that's what the translator has to do, not to think, well, some people wouldn't like this or some people would be upset by whatever. That's not the translator's business to think about [...]. When I'm doing the editing I have some sense of how would readers think about that."

58 "When I try to translate any book, the intention is to create in English the resonances within the style of the original and that for me is the priority."

59 "I think that a right translation is a translation that captures the original rhythm of the book."
} 
americana e britânica que tenho lido ou possa ler com relação à tradução que esteja fazendo."

O tradutor afirma ainda não ter conhecimento da crítica sobre a tradução de Estorvo na Inglaterra, pois esse tipo de crítica praticamente não existe: "Na Inglaterra, frequentemente acontece de uma tradução ser publicada e não ser resenhada". ${ }^{61}$ Ao contrário de países como Brasil, Espanha e Portugal, onde muitos dos livros publicados são traduções, na Inglaterra, as traduções não são comentadas pela crítica. Já na Austrália, segundo Bush, foi publicada uma crítica dizendo que a sua tradução de Estorvo era muito britânica. Contudo, como informa Bush, Chico Buarque, quando do lançamento de Estorvo na Inglaterra, recebeu da imprensa daquele país, graças ao empenho da editora Bloomsbury, um tratamento diferenciado com relação a diferentes autores: "Chico teve mais cobertura da imprensa no Reino Unido do que a maioria dos autores estreiantes, porque a Bloomsbury se empenhou para divulgar o romance". 62

Bush não acredita que as traduções da obra de Chico Buarque tenham causado algum tipo de influência nas culturas dos países de língua inglesa onde as obras são publicadas. Entretanto, pensa que a literatura traduzida pode causar repercussão nas culturas de chegada, ao produzirem impacto nas elites literárias desses países.

Para ele, os leitores de literatura traduzida na Inglaterra fazem parte de um grupo intelectualmente restrito e Chico Buarque é lido por essa elite

\footnotetext{
60 "I mean, for instance my translations might be influenced more by English and American literature I've been reading or I might read in relation to the translation I'm doing."

61 "in England, it often happens that a translation would come out and no one would get it reviewed."

62 "Chico got more coverage in the UK press than most writers publishing their first novels, because Bloomsbury did a lot to publicize the novel"
} 
literária. Mesmo desconhecendo os números, estima que o volume de vendas das traduções dos livros de Chico Buarque para o inglês não é expressivo. Apesar de a maioria das obras traduzidas venderem pouco, se comparadas às obras originalmente escritas em inglês, algumas poucas traduções podem se tornar best sellers, como é o caso do romance The Shadow of the Wind, do escritor espanhol Carlos Ruiz Zafón, exemplifica Bush.

Ao contrário de alguns livros que são originalmente de leituras fáceis, Estorvo é, na opinião de Bush, um livro que exige mais do leitor e seria insensato se um editor quisesse transformar Estorvo em um livro de leitura fácil:

Mas é verdade que alguns livros em suas línguas originais não são muito exigentes; eles são de fácil leitura, são os best sellers. E então há outros livros que exigem mais, como Estorvo, e seria absurdo se um editor quisesse criar a partir de Estorvo um livro que fosse facilmente legível.

Para o tradutor, nesse caso, não faria sentido publicar o livro. Ele reafirma que é dever do tradutor recriar o ritmo contido no original e se houvesse um editor que desejasse eliminar esse traço de originalidade, o tradutor deveria se posicionar contra ele:

Então, acho que o trabalho do tradutor, o papel do tradutor é recriar o que está no ritmo do original, e se houver um editor que queira meio que apagar essa originalidade, então o tradutor deve defender a originalidade contra 0 editor. ${ }^{63}$

Bush declarou ter traduzido mais de cinquenta livros durante sua carreira e ao longo dessa trajetória deparou com um único editor que desejou mudar radicalmente a sua tradução, de forma que ficasse diferente do original. A tradução de Estorvo, nas palavras de Bush, retrata uma situação na qual tanto o autor quanto o editor estrangeiro recusaram a primeira tradução pelo fato de

\footnotetext{
63 "So I think the job of the translator, the role of the translator is to recreate what is in the rhythm in the original, and if there might be an editor who wants to kind of erase that originality then the translator has to defend the originality against the editor".
} 
ela ser fluente. Esse é, segundo Bush, um bom exemplo de editor que privilegia uma tradução não facilitadora para os leitores da cultura de chegada. Tal postura dos editores da Bloomsbury contraria a afirmação do tradutor e teórico Lawrence Venuti (1995, p.1) que a obra traduzida é legitimada pela maioria dos editores quando se apresenta fluente, ou seja, quando não causa nenhum tipo de estranhamento ao leitor da língua de chegada.

\subsection{Clifford Landers}

O norte-americano Clifford E. Landers ${ }^{64}$ deu voz, em inglês, ao segundo romance de Chico Buarque, Benjamim. Conforme relatos em entrevista concedida, em português, a este pesquisador, em julho de 2007, iniciou sua carreira como tradutor de literatura brasileira por volta de 1985 por sugestão de sua mulher: "Por que você não faz alguma coisa com o seu conhecimento de português? Por que não faz tradução literária?" Landers, que até aquele momento nunca havia pensado nessa possibilidade, recebeu de presente do pai de sua esposa duas coletâneas de Rubem Fonseca, Feliz Ano Novo e O Cobrador. Encantou-se pela obra de Rubem Fonseca e, atendendo ao convite para publicar um conto em uma edição especial da revista Review ${ }^{65}$, Landers escolheu 'O Jogo do Morto", a que deu o título, segundo o próprio tradutor, "meio melodramático" de The Game of the Dead Man. Com esse trabalho, chamou a atenção do agente literário, Thomas Colti - que mais tarde tornou-se

\footnotetext{
${ }^{64}$ Tradutor e professor emérito de Ciências Políticas da New Jersey City University, Recebeu a premiação Mario Ferreira Awards, em 1999, pela sua contribuição como tradutor de Literatura Brasileira. Seu livro Literary Translation: A Practical Guide foi publicado pela editora Multillingual Matters Ltd em 2001. Morando atualmente na cidade de Naples no estado da Flórida, EUA, é casado com a brasileira Vasda Bonafini Landers, professora da Columbia University, onde lecionou Literatura Brasileira por vinte e dois anos. Landers esteve no Brasil pela primeira vez em meados da década de 1960, quando fazia pesquisa para sua tese de doutorado sobre o extinto partido político brasileiro UDN.

${ }^{65}$ Revista publicada pelo Centro de Estudos Ítalo-americanos, em Nova lorque, EUA.
} 
seu empresário - passando a receber ofertas de editoras para traduzir outras obras de autores brasileiros. Desde então, traduziu mais de vinte títulos de autores brasileiros tais como: Rubem Fonseca, Jorge Amado, João Ubaldo, Patrícia Melo, Jô Soares, Chico Buarque, Paulo Coelho, Marcos Rey, José de Alencar, Lima Barreto, Osman Lins, Moacyr Scliar, Raquel de Queiroz e Paulo Lins.

O convite para tradução de Benjamim partiu da editora inglesa Bloomsbury. Landers já havia publicado por essa editora sua primeira tradução de um romance de Rubem Fonseca, "Vastas emoções e pensamentos imperfeitos", cujo título em inglês foi Lost Man. O tradutor declarou não ter gostado da opção feita pela Bloomsbury e comenta que, na edição americana, publicada nos Estados Unidos um ano mais tarde, "deram o título certo, ou seja, Lost Emotions and Imperfect Thoughts". Tendo, na ocasião desta entrevista, traduzido várias obras de autores brasileiros, Landers expressa a sua satisfação com relação à política editoral da Bloomsbury sobre obras traduzidas:

$\mathrm{Eu}$, sinceramente, fico muito contente com o fato de a Bloomsbury ser umas das poucas editoras que estejam abertas à tradução, principalmente às obras do Brasil, e isso se deve a Liz Calder [...] a Bloomsbury nunca mudou nada que eu traduzisse.

O tradutor ainda ressalta, positivamente, o fato de a editora, apesar de inglesa, dar ao tradutor a opção de traduzir Benjamim para o inglês americano, sem nenhuma restrição: "eu fiz questão de perguntar no início: vocês querem uma tradução para o inglês americano ou britânico" [...] "e eles disseram: inglês americano está perfeitamente bem.”

Chico Buarque, que estava em Paris naquela época, manteve longas conversas com Landers ao telefone sobre a tradução de Benjamim. Ao falar 
sobre o grau de interferência do autor, o tradutor prefere usar a palavra "participação". De modo geral, ele aprecia a cooperação do autor: "eu não levo a mal que o autor queira participar, muito pelo contrário, eu até gosto que ele entre com as ideias, que dê palite, sabe?" Contudo, argumenta: "é necessário que a palavra final fique com o tradutor ou, em alguns casos, com o editor". Para ele, dialogar com o autor durante o processo de tradução é muito importante: "Porque aí eu posso conferir com ele sobre quaisquer dúvidas". Mas recorrer ao autor apenas em último caso:

[...] faço o possível para reduzir ao mínimo o número de perguntas [...] não quero ser um chato [...] faço o possível para resolver as dúvidas com outras pessoas primeiro [...]. Às vezes, não é possível [...] só aí vou conferir com o autor.

Segundo Landers, de todos os trabalhos por ele realizados, a tradução de Benjamim foi a que teve a maior participação do autor, ela foi

[...] a tradução mais, vamos dizer, monitorada que já fiz, porque o Chico queria sentir sua presença na tradução; ele queria que fosse uma coisa digna do texto, afinal, ele é profissional da palavra também. [...] dos autores que já traduzi, ele era o mais, digamos, envolvido na tradução.

Como exemplo de uma atitude oposta a de Chico Buarque, Landers cita a postura do escritor Jô Soares diante das traduções de suas obras:

[...] quando traduzi as duas obras de Jô Soares, Jô me dava carta branca; eu podia mudar qualquer coisa, contanto que mantivesse 0 tom da obra. Por exemplo, uma piada: eu podia modificar a piada para que saísse uma coisa graciosa para o leitor americano.

Landers ressalta a reputação de Chico Buarque como um dedicado burilador de palavras, que delas cuida com todo zelo, para traduzirem fielmente suas intenções: "[...] ele era muito digamos, não diria ciumento, mas ele cuidava muito da proteção das palavras dele, dos pensamentos". Como exemplo disso, o tradutor relata uma conversa que tiveram sobre um tipo de sorriso: 
Eu me lembro que ele até fez um desenho para mostrar o que tinha em mente ao falar dos gomos do sorriso. Isso também tinha pouco sentido; eu não entendia exatamente onde que ele queria chegar, "então, quando você corta uma laranja, cada gomo desses...", dizia Chico - Ele quis dizer que seria um sorriso desse tipo.

Mas, como afirma o tradutor, "gomo" de laranja seria muito difícil de traduzir porque não há na língua inglesa "uma palavra exata para gomo de laranja". Segundo Landers, poderia usar a palavra wedge, que significa "cunha”, mas "cunha” é uma palavra mais genérica, em sua opinião.

Durante o processo da tradução de Benjamim, Landers seguiu as mesmas etapas de suas outras traduções, ou seja: "antes de aceitar qualquer projeto, qualquer proposta de tradução, eu faço questão de ler a obra completamente". Ele considera a leitura completa do livro essencial para avaliar não só o seu interesse pela obra como também a sua capacidade para aceitar tal empreitada.

Em sua opinião, algumas obras extrapolam os seus limites como tradutor: "[...] eu nunca atreveria a traduzir, por exemplo, "Macunaíma" ou "O Grande Sertão Veredas", que eu acho intraduzíveis, de modo geral." Após aceitar a proposta de traduzir a obra, relê a obra, pelo menos mais uma vez, pois desta forma, é possível "antecipar certos problemas" textuais, "ficar ciente do foreshadow" assim como ter "uma ideia melhor do ritmo que precisa manter para levar a cabo a tradução." Suas traduções são feitas de forma linear: "Eu, geralmente, começo pela primeira página e vou até o final", este é "meu jeito de trabalhar; outros tradutores usam outra abordagem."

Antes de tecer qualquer comentário sobre a recepção da tradução de Benjamim nos EUA, Landers ressalta alguns aspectos relacionados à recepção de obras traduzidas pelos leitores desse país: 
[...] existe uma resistência à tradução. De modo geral, o americano não gosta de ler coisas traduzidas; [...] com poucas exceções - [...] Kundera, Xirmapis, Torres -, o americano só quer ler uma coisa escrita originalmente em língua inglesa. Portanto, uma tradução, já desde o início, a priori, encontra obstáculos primeiro para ser publicada e depois para ser acolhida pelo público americano.

Na esteira dessas ponderações, Landers afirma que o "povo pensante" de seu país não é superior a, aproximadamente, $15 \%$ da população. E, portanto, para buscar a consciência do grande público americano, uma tradução necessita de uma campanha publicitária maciça. Nesse setor, as traduções deparam com uma concorrência brutal imposta pelas obras originalmente produzidas em inglês, pois existe uma discrepância enorme entre elas no mercado editorial americano. Ainda, segundo Landers, existe uma correlação positiva entre o número de resenhas publicadas sobre um livro e o seu índice de vendagem: "[...] o número de livros vendidos é em função do número de resenhas que a obra recebe. Uma boa resenha, por exemplo, no New York Times, pode dizer muito." Como exemplo, ele cita o fenômeno editorial "O Código Da Vinci": "tudo começou com uma resenha estupenda que saiu na primeira página do New York Times."

E, voltando a falar sobre a crítica de tradução naquele país, conclui: "a crítica, [...], nem liga para uma tradução; a crítica, [...], julga a obra como se fosse [...] escrita originalmente em inglês". De acordo com Landers, o nome do tradutor é geralmente mencionado e quando se trata de uma boa tradução aparecem frases, tais como: "Numa tradução competente" ou "Numa tradução brilhante". Contudo, se o tradutor errar, daí ele "merece uma crítica, geralmente um parágrafo ou duas ou três frases". Ele finaliza dizendo que "nenhuma referência à tradução já é aceita como um elogio" pelo tradutor literário. Diante 
da ausência de comentários sobre as traduções, as resenhas publicadas sobre as obras "são um tipo de comunicação sobre a tradução".

As únicas resenhas sobre Benjamim lidas pelo tradutor foram aquelas publicadas na Inglaterra. Contudo, não informou se, dentre elas, havia alguma menção à sua tradução especificamente.

Por outro lado e respondendo à sua própria pergunta sobre o perfil do leitor de tradução nos Estados Unidos, Landers afirma que: "são pessoas, de modo geral, com grau de escolaridade superior, [...] que têm algum conhecimento de outras culturas, mas de outras línguas geralmente não [...]".

Ele lamenta a resistência dos americanos ao aprendizado de outras línguas: "[...] o americano é avesso a aprender outros idiomas, infelizmente. Com poucas exceções, a atitude do americano é que eles aprendam o inglês" e diz que esse fato "se vê também entre os ingleses, infelizmente; acho que herdamos deles". Segundo Landers, quando se encontra uma pessoa bilíngue nos Estados Unidos, esse aprendizado ocorreu devido ao fato de o idioma ser falado em casa - como exemplo, ele cita as famílias de origem hispânica vivendo naquele país -; de se tratar de um estrangeiro radicado nos Estados Unidos ou de um acadêmico "que, por vários motivos, teve que aprender outro idioma".

Ao falar de sua "abordagem à tradução", Landers cita como referência o linguista e teórico, Peter Newmark (1991), que "divide os tradutores literários em: sourcereers e targeteers". Ele, de antemão, se considera pertencente à última categoria proposta pelo teórico: 
Eu sou targeteer, como falei no livro ${ }^{66}$, ou seja, se tenho que dar privilégio ou preferência ao autor ou ao leitor potencial, eu opto pelo segundo, ou seja, para mim é muito mais importante que o leitor entenda e perceba a obra como uma coisa natural, uma coisa corrente $[\ldots]$.

Em seguida, quando foi perguntado a ele se seria importante para ele, como tradutor, remeter o leitor à cultura de partida, o tradutor afirma não ser esse o seu principal propósito quando ele traduz uma obra literária:

Se isso acontece, deve ser um subproduto de tradução, ou seja, isso não é minha intenção primordial. Eu acho que em se tratando da tradução de uma obra de outra cultura [...] a própria escrita já remete à cultura de origem, entendeu? E, portanto, eu não vejo necessidade de enfatizar os elementos exóticos, ou estrangeiros, ou até estranhos, esquisitos da obra; acho que isso vem mais ou menos automaticamente. Mas a minha abordagem sempre foi a de maximizar, digamos, o entendimento do leitor e minimizar as ocasiões em que ele se pergunta: "de que se trata?" e diz: "não entendo o que o autor quer dizer".

Assim, para Landers, ser um targeteer, um tradutor cuja prática tradutória está voltada para o leitor e a cultura de chegada, significa desde sempre "maximizar, digamos, o entendimento do leitor e minimizar as ocasiões em que ele se pergunta: 'de que se trata?' E diz: 'não entendo o que o autor quer dizer". Tudo isso, sem "lesar a cultura original".

Landers não se considera um teórico da tradução e sim um "pragmático" e afirma ser um tradutor cuja prática volta-se para o leitor e a cultura de chegada, sem, contudo, gerar o apagamento da cultura de partida. Para ele, confessa o tradutor, seu papel é o de servir de elo entre as duas culturas envolvidas no processo tradutório, mesmo que, para isso, tenha que adequar a sua tradução aos padrões estéticos da cultura de chegada. Atuando dessa forma, o tradutor acredita contribuir para que os leitores dos Estados Unidos possam visitar outras culturas, principalmente aquelas localizadas no hemisfério sul, como a brasileira e a argentina, pois quando o povo americano

\footnotetext{
${ }^{66}$ Landers se refere ao já citado livro de sua autoria Literary Translation. A Practical Guide, no qual ele comenta sobre os conceitos "trageteers" e "sourcerers" nas páginas 51 e 52.
} 
"olha além das fronteiras dos Estados Unidos, ele não olha para o sul; ele olha para a Europa":

Eu, de preferência, levo o autor ao leitor, isto é, eu quero servir de ponte entre duas culturas. Como eu já falei, o que o tradutor literário faz, principalmente, é traduzir culturas, e não palavras, nem ideias, mas é através da tradução das palavras e das ideias que ele chega a traduzir culturas. Então, levar o autor para o leitor é muito importante na cultura americana, porque, infelizmente, o leitor americano não se dá ao esforço de conhecer outras culturas. [...]. Portanto, é muito importante para mim, vencer, superar essa relutância em mergulhar em outra cultura; e o jeito de conseguir isso, a meu ver, no meu juízo, é facilitar a passagem de uma cultura para outra, sem lesar, sem fazer dano à cultura de origem.

Reiterando a sua postura de targeteer, o tradutor, mesmo ressaltando o seu respeito ao teórico Lawrence Venuti, contesta: "[...] eu nunca faria o que não sei se posso dizer o que ele faz - mas o que ele advoga, ou seja, propositadamente introduzir elementos estrangeirizadores no texto." Pois, no original, afirma ele,

[...] já existem elementos suficientes para marcar a obra como oriunda de outra cultura, torcer a gramática da língua de chegada para que se reflita a de origem, não faz meu gênero, não faço nada disso [...] essa não é minha filosofia ou abordagem. Eu sou pragmático.

Ainda sobre a "abordagem" de tradução por ele adotada, Landers enfatiza que traduz ideia por ideia e não palavra por palavra. $\mathrm{O}$ importante, para ele, é a ideia, "principalmente em se tratando de cenas emocionantes, xingamentos: "no Brasil dizem FDP; claro que eu teria que traduzir para o inglês como son of a bitch, porque não existe na nossa cultura a ideia de son of a whore". Ele considera o novo "literalismo", a que se refere Marilyn Rose $(1993)^{67}$ "um passo atrás, uma coisa retrógrada; eu nunca iria deixar isso influenciar o jeito de traduzir".

\footnotetext{
${ }^{67}$ A autora argumenta que estamos vivenciando um novo "literalismo", ou seja, o renascimento de uma prática de tradução que está historicamente relacionada à tradução palavra por palavra.
} 
Segundo a ótica de Landers, o maior desafio para o tradutor literário consisou seja, com a metalinguagem". Referindo-se a esse tipo de dificuldade, o tradutor menciona as traduções das crônicas de Millôr Fernandes que estava realizando na época em que a entrevista foi realizada: “[...] ele é muito brincalhão; adora brincar com as palavras, e às vezes as alusões são coisas que somente um brasileiro iria entender".

Ressalta, sobre esses aspectos, que as alusões aos elementos da cultura de origem representam um grande problema para o tradutor: "chega a um ponto em que, às vezes, o tradutor tem que se dar por vencido". E, nesses casos, há de se "passar por cima de certas coisas, esperar que o leitor americano nem ligue para isso ou que aceite os limites da tradução".

Segundo Landers, no caso de um livro sobre culinária, o tradutor poderia explicar em uma nota de pé de página o significado da palavra vatapá. O mesmo poderia ser feito com relação ao papel do carnaval na cultura brasileira em um tratado sociológico. Contudo, em uma tradução literária, se recusa a adotar essa prática porque "[...] destrói o efeito mimético da prosa. Eu não acho que tenho o direito de fazer isso". O tradutor pode, no máximo, escrever um adendo no início ou no final do livro e cita como exemplo, o fato de ter inserido uma "nota do tradutor" de uma página e meia no prefácio do romance "Iracema", explicando o tratamento que ele dispensou às palavras de origem indígena contidas na obra de José de Alencar.

Landers considera "justificável" a inclusão de uma breve explicação no corpo do texto como forma de compartilhar com o leitor da cultura de chegada o conhecimento que o leitor da cultura de partida já possui sobre determinado assunto ou personagem. Exemplificando, ele cita Elis Regina e diz que poderia 
acrescentar ao referido nome a seguinte informação: "uma cantora popular, uma grande figura da MPB". Mas, afirma que não "teria o direito" de substituí-la por uma cantora americana. Ele faria o mesmo com relação aos personagens históricos como Getúlio Vargas, acrescentando como nota do tradutor a informação de que se trata de um ex-presidente do Brasil.

No que concerne à tradução de dialetos, gírias e expressões coloquiais, Landers se posiciona dizendo que essas variações linguísticas são produtos de "um determinado momento histórico cronológico e de um lugar geográfico" e tentar transferir o jeito de falar de um nordestino para o sul dos EUA não seria adequado porque, segundo o tradutor, "as associações que o leitor vai fazer são falsas, vão deturpar o entendimento do leitor, a apreciação de outra cultura." Portanto, ao se deparar com um dialeto, ele recomenda que o tradutor faça "uso de um linguajar meio generalizado", com o objetivo de passar a ideia de "que se trata, por exemplo, de um homem do campo ou de um favelado". Contudo, "tentar criar um novo dialeto" é, em sua opinião, "a pior coisa que um tradutor pode fazer".

Respondendo sobre as dificuldades de traduzir para 0 inglês as diferenças entre não somente os registros formais e informais, como também as linguagens oral e escrita - tão marcantes na língua portuguesa -, Landers ressalta que na língua inglesa essas diferenças não são tão acentuadas. Ele ilustra sua percepção, citando um de seus grandes desafios com tradutor: a "adaptação", por ele assim chamada, do conto "O Colocador de Pronomes", de Monteiro Lobato. Em sua opinião, "a colocação de pronomes não representa um problema na língua inglesa". Portando, já de início, o título foi traduzido por The Grammarian e o tradutor optou por compensar o jogo com o emprego dos 
pronomes presentes no conto original pelo uso de "problemas gramaticais oriundos do inglês" na tradução.

Quanto ao resultado desse esforço tradutório, ele não garante ter acertado e deixa o julgamento nas mãos do leitor, ele "que o diga". Na concepção de Landers, a tradução é um jogo de compensações, pois "nunca vai existir uma correspondência perfeita entre os elementos linguísticos de um idioma e outro; sempre é preciso adaptar a diferença”. Estendendo seus comentários acerca do assunto, ele afirma que "qualquer tradução literária é um trabalho de opções, porque tem que se escolher dentre muitas possibilidades". Comparando o seu papel ao de um leitor, ele afirma que, acima de tudo, "o tradutor literário é como um leitor sumamente cuidadoso; ele tem que entender cada santa palavra do original." Já o leitor comum não tem esse compromisso.

Embora Landers não se lembrasse de detalhes sobre a tradução de Benjamim, pois na época de nossa entrevista já se passaram dez anos desde a sua publicação, ele finaliza afirmando ter gostado da obra e da oportunidade de participar de sua divulgação para outra cultura. Benjamim é, em sua opinião, "uma obra literária digna" e o seu autor "é um homem de muitos talentos, não somente na música, mas também na literatura", e já começou a "ter um papel, um lugar na literatura brasileira”.

Para ele, Chico Buarque está para a cultura brasileira assim como Garcia Marquez está para cultura colombiana e William Faulkner para cultura americana: "Chico é uma voz brasileira única, [...] Chico é um produto da cultura brasileira. Embora sua personalidade ou seu dom para com as palavras possam ser traduzidos, ele sempre vai ter suas raízes na cultura brasileira”. 
Aliás, a visão de Landers a esse respeito representa, em última análise, uma opinião hegemônica no meio intelectual, artístico e cultural do Brasil.

\subsection{Alison Entrekin}

A tradutora australiana Alison Entrekin ${ }^{68}$, ao saber que Chico Buarque lançaria o seu terceiro romance, decidiu que gostaria de publicar sua tradução. Assim que o livro chegou às prateleiras das livrarias, tratou de comprá-lo e traduziu o primeiro capítulo como um sample chapter, uma amostragem. Em seguida, ligou para a editora Companhia da Letras e foi informada de que os direitos da tradução de Budapeste para o inglês já haviam sido negociados com editora inglesa Bloomsbury. De posse dessa informação, entrou em contato com a assistente de Liz Calder, apresentou-se como interessada em fazer a tradução da referida obra, encaminhou a tradução que havia feito do primeiro capítulo e acabou se tornando a tradutora de Budapeste para o inglês. Foi uma tradução rápida, em sete semanas ela havia concluído a tradução do livro que o autor levara dois anos para finalizar. Depois disso, foram vários os telefones e e-mails trocados com o autor até a publicação da obra.

Segundo Alison, a editora inglesa não fez o cotejo da obra com o português, os copy editors ou "preparadores de textos", como a tradutora denomina os profissionais responsáveis pela revisão da tradução, fizeram

${ }_{68}$ A premiada tradutora de Budapeste atualmente reside no Brasil, onde trabalha como tradutora autônoma para editoras brasileiras e estrangeiras, como a inglesa Bloomsbury. Nasceu nos Estados Unidos, mas foi criada na Austrália, onde se graduou em creative writing, criação literária, pela Curtin University. Realizou estudos na área de tradução no Institute of Linguistics, na Inglaterra, e na Associação Alumni, no Brasil. É membro da American Literary Translators Association nos Estados Unidos. Alison já traduziu mais de quarenta títulos entre ficção e não-ficção. Dentre as obras ficcionais de autores brasileiros traduziu, por exemplo, "Cidade de Deus", de Paulo Lins, e "O Dia Em Que Matei Meu Pai", de Mario Sabino *. Em 2002, recebeu a American Literary Translators' Association Fellowship pela tradução dos contos da escritora brasileira Augusta Faro. 
pequenas modificações "de acordo com as regras da casa". Ela afirma não ter recebido recomendações específicas com relação ao tipo de tradução que deveria fazer. Contudo, existia a preocupação tanto da editora quanto da tradutora de que o inglês usado na tradução fosse inteligível "dos dois lados do Atlântico". Ela afirma que não poderia usar o inglês australiano, utilizando expressões que são peculiares de seus falantes, nem o inglês estritamente britânico, porque não se sentia tão qualificada para isso, tampouco o inglês americano, por não ter o domínio amplo de expressões utilizadas por eles.

Diante disso, a tradutora propôs que se fizesse uma tradução para o inglês da comunidade britânica, que, em sua opinião "seria uma coisa um pouco mais neutra." A edição americana manteve a tradução de Alison sem nenhuma alteração, nem mesmo a ortografia foi alterada, reitera a tradutora.

Sobre a atuação de Chico Buarque na tradução de Budapeste, Alison relatou na entrevista concedida a este pesquisador que o autor entrou em contato com ela após a leitura do primeiro capítulo do livro, que lhe fora envido pela editora. A participação do autor foi muito bem recebida por ela: "às vezes, o autor interfere muito na tradução, e às vezes eu me irrito, mas eu vi que ele", referindo-se a Chico Buarque, "não ia atrapalhar em nada; ele só ia acrescentar". Na medida em que ela concluía um capítulo, ele era enviado ao autor que o devolvia com suas "observações e perguntas", via e-mail. $\mathrm{O}$ fechamento dos capítulos geralmente acontecia após conversas ao telefone.

A tradutora afirma que sempre teve oportunidade de conversar com os autores das obras que traduziu e Chico Buarque "foi o mais participante. [...] ele dava palpite que me ajudava a melhorar a tradução, nas coisas que são inerentes ao original, que, talvez, eu não tivesse percebido". A condição de 
partícipe do autor e sua reputação de amante de palavras podem ser retratadas na seguinte passagem da entrevista: [...] ele foi mais de auxiliar, de falar 'olha esse adjetivo na página $x$, por exemplo, tem que ser o mesmo que está lá na página y, porque eu tive que repetir a mesma estrutura da frase nesses dois lugares'.

No trecho acima, Alison refere-se ao episódio no qual Chico Buarque solicita que os adjetivos "soltos" e "soltas", contidos nos excertos abaixo, fossem traduzidos pela mesma palavra em inglês, como forma de garantir a recriação de sua intencionalidade.

Ao primeiro contato, o idioma, o clima, a alimentação, a cidade, as pessoas, tudo, tudo em pareceu tão absurdo e hostil que caí de cama, e ao me levantar dias mais tarde, vi horrorizado meu corpo pelado e meus pêlos soltos no lençol. (BUDAPESTE, 2003, p. 29)

At first the language, the climate, the food, the city, the people, everything, everything struck me as so absurd and hostile that I fell ill, and when I got out of bed days later, I saw in horror my naked body and my hair scattered across the sheet. (BUDAPEST, 2003, p. 26-27)

Palavras recém-escritas, com a mesma rapidez com que haviam sido escritas, iam deixando de me pertencer. Eu via minhas palavras soltas na tela e, horrorizado, imaginava que elas me abandonavam como o alemão perdia pêlos.

Recently written words, with the same speed with which they had been written, ceased to belong to me. I saw my words scattered across the screen and, in horror, imagined they were abandoning me as the German had lost his hair. (BUDAPEST, 2003, p. 39)

O processo de tradução de Budapeste descrito por Alison ratifica a participação de Chico Buarque no seu trabalho. Após a execução de cada capítulo, a tradutora o revisava "mil vezes". Posteriormente, compartilhava as suas dúvidas com uma amiga tradutora brasileira que traduz na direção oposta. 
As dúvidas não giravam tanto em torno da interpretação do texto, mas com relação ao "efeito" que determinada palavra ou frase cria no leitor: "[...] cria estranhamento ou não cria?", "Você dá gargalhada na hora em que você lê essa frase ou não?". Depois de outra revisão, o texto era encaminhado ao autor, que, como foi mencionado anteriormente, o devolvia com suas observações. A etapa final do processo foi assim descrito pela tradutora:

[...] depois de me preocupar mais com o original [...] tem um momento em que eu abandono o original e faço uma revisão em inglês, justamente procurando por aquelas coisas que me causam estranhamento; aí eu volto para o original, para ver se esse estranhamento está lá também, então eu faço essa revisão em inglês.

Alison considera difícil a tarefa de definir o estilo literário de Chico Buarque e afirma que dentre as obras de autores brasileiros que já traduziu "todos difíceis e nenhum nada a ver com o outro" -, Budapeste não apresentou barreiras culturais a serem transpostas: "Eu não sentia que tinha sacrifício nessa tradução; eu senti que passava todo o conteúdo e estilo sem problemas", pois

[...] tudo que acontece em Budapeste está contido no livro. Todas as informações que você precisa para entender o enredo, entender o que está acontecendo, estão contidas no livro; acontece na cabeça do personagem principal. E a Budapeste do livro é uma Budapeste imaginária, não é real. O Rio também é visto pela lente do personagem principal. Então, era super contido; não tinha esse problema cultural $[\ldots]$

O mesmo não ocorreu com a tradução de "Cidade de Deus", de Paulo Lins, que apesar de ter sido uma experiência tradutória muito importante, "[...] foi uma experiência terrível, porque é uma cultura que não dá para transpor, não tem equivalente cultural na realidade dos países de língua inglesa. Essa foi a maior dificuldade; não a parte linguística, mas a parte cultural”.

No que concerne à estratégia utilizada pela tradutora para lidar com as variações de registro contidas em Budapeste, ela afirma que em suas 
traduções cada caso é tratado individualmente, não existe "uma abordagem fixa para absolutamente nada". Contudo, ela sempre busca "uma expressão equivalente que, além de passar o sentido, também tenha o mesmo tom, humor, o colorido da expressão" da língua de partida. Na ausência de um "equivalente", a tradutora afirma não ser "contra" fazer uma tradução mais próxima do original, "ao pé da letra em inglês", desde que "o sentido" fique "claro" e se mantenha "a graça do original"..

Embora a tradutora considere a sua tradução "um pouco target oriented", ou seja, voltada para a cultura de chegada, ela afirma não ter tido essa preocupação durante a realização de seu trabalho: "essa questão não entrou muito nas decisões". Alison mencionou na entrevista que ouviu comentários de pessoas dizendo que a obra traduzida parecia ter sido originalmente escrita em inglês: "As pessoas falam que [...] não se tem a sensação de que está lendo uma coisa traduzida."

Alison afirma não saber precisar o perfil do leitor da obra de Chico Buarque em inglês. Talvez leitores que, assim como ela, gostam de literatura mundial: "Eu acho que têm pessoas como eu [...] que se interessam pela world literature e que vão procurar sempre produções de outras culturas, de outros países". Ela acredita que o mercado de literatura traduzida em países de língua inglesa "é muito restrito". Tal limitação, segundo a tradutora, deve-se ao fato de esses países possuírem uma produção editorial muito grande em sua própria língua, inclusive, de obras sobre outras culturas originalmente escritas em inglês pelos descendentes de seus ex-colonizados.

Outro fator apontado por ela é o preço mais alto das obras traduzidas, pois agregam custos adicionais com a compra de direitos autorais e 
contratação de tradutores. Os livros brasileiros traduzidos no exterior são "best sellers em português", afirma a tradutora. E os perfis dos leitores variam de acordo com a obra. No caso de Chico Buarque, ela acredita que os leitores são admiradores, inicialmente motivados pelo prestígio e reconhecimento que ele tem como compositor e cantor: "As pessoas [...] leem Chico Buarque [...] porque amam o que ele faz na música e têm interesse por tudo que ele faz, então compram o livro também". Contudo, ela comenta que talvez essa tendência tenha mudado, haja vista que o autor, na ocasião da entrevista, já havia publicado seu terceiro romance.

A tradutora acredita que o perfil do leitor da tradução é "de certa forma" igual ao do leitor da obra original. Portanto, ela entende que, ao ser fiel ao original, ela está compartilhando com o autor o mesmo perfil leitor: "A tradução, a meu ver, tem que ser fiel ao original, então eu não posso escolher outro público-alvo que não seja o que o próprio autor escolheu".

Ela considera "estranhíssimos" os casos extremos de adequação da obra original à cultura de chegada. Como exemplo, ela menciona a mudança do espaço dramático de um romance que, originalmente, se passava em Lisboa e que foi alterado para Londres. Alison acredita que o seu papel como tradutora seja "pegar o leitor pela mão" e conduzi-lo "à realidade do livro", ou seja, a tradução dever servir como um passaporte para o leitor da língua de chegada visitar a realidade da cultura de partida: "quanto mais denso e rico o texto em detalhes culturais, maior a viagem desse leitor de língua inglesa". Isso ocorreu em "Cidade de Deus", mas em Budapeste, devido á temática do livro, "eu senti que isso não foi grande", comenta a tradutora. 
$\mathrm{Na}$ opinião da tradutora, o registro de linguagem usado pelo autor em Budapeste não representou um problema, principalmente, se comparado ao livro "Cidade de Deus". Alison ressalta o fato da obra Budapeste ter "um registro mais alto". Já a pontuação trouxe problemas e foi assunto de conversas entre Alison e Chico Buarque: "eu tive uma preocupação muito grande em acertar a pontuação, isso foi uma coisa super discutida com o Chico também". Segundo Alison, o autor observava a divergência da pontuação na tradução com relação ao original: "mas você pontuou assim, eu fiz assado". As negociações só eram concluídas quando ela the apresentava uma justificativa convincente: "[...] o mais difícil foi acertar essa coisa da pontuação. Quando ela tinha uma explicação que o satisfizesse, ele aceitava e me deixava fazer dessa forma". Contudo, "até chegar nessa explicação", levava-se um tempo.

A tradutora declara ter respeitado a intenção original de Chico Buarque ao manter a pontuação original em sua tradução, mesmo em casos onde o uso de uma pontuação diferente fosse, aparentemente, mais apropriado. Sempre que surgia uma dúvida sobre a pontuação ela perguntava, por exemplo, o que ele pretendia com a colocação daquela vírgula, caso não houvesse da parte dele a intenção de causar um estranhamento no original e naquele trecho o texto devesse "fluir normalmente", então a tradutora usou um ponto final para que soasse fluente em inglês também. Nesse caso, a discrepância no uso da pontuação foi justificada pela manutenção do estilo do autor.

Outro desafio encontrado por Alison foi traduzir os jogos de linguagem propostos por Chico Buarque: 
[...] o que me deu mais trabalho foram aquelas brincadeirinhas com palavras que ele faz. Por exemplo, ele está no bar com os ciganos, e a menina vira para ele no bar e fala para o namorado dela: "Eu vou levar esse cara pra cama", "Na cama comigo esse cara vai ver o que é bom". Ele fazia umas brincadeiras com as palavras repetindo, reorganizando, e a dificuldade na tradução é reproduzir esses jogos, mas nada que não fosse possível de recuperar.

A tradução desse jogo com as palavras, resultado do hábil uso de linguagem pelo autor, foi considerado pela tradutora um exercício de "reconstrução", como a montagem de "um gigante quebra-cabeça" cheio de brincadeiras sutis. Nesses casos, a sua intenção como tradutora era oferecer ao leitor da tradução a mesma experiência de leitura vivenciada pelo leitor da obra original: "eu queria que o leitor desse a mesma gargalhada, na mesma hora, pelo mesmo motivo".

No caso específico de Chico Buarque, Alison afirma que nada em sua obra está lá por acaso, "cada palavra, cada vírgula", tudo é "muito planejado, muito estruturado". Na concepção da tradutora, "não tem nada que fuja à intenção dele". Ela ressalta que a sua prática tradutória é orientada pela intenção do autor:

Eu acho que eu tenho que obedecer ao que o autor pretende com o texto original. Então, se ele pretende criar um estranhamento, eu tento recriar o mesmo estranhamento. Se ele não pretende, eu tenho que ter muito cuidado para não introduzir alguma coisa que vá causar estranhamento. Por isso que eu digo que minha estrela guia é isto, recriar essa experiência para o leitor.

Contudo, a tradutora admite que, se necessário, "em alguns momentos", acrescenta "algum detalhe facilitador, uma palavrinha a mais, embutida para ajudar na compreensão". Explica que, nesses casos, sempre tem como objetivo o resgate da intenção do autor, quando é possível conhecê-la, e a recriação daquilo que ela chama de "experiência de leitura para o leitor da tradução". 
Como exemplo de sua devoção às intenções do autor e à sua obra, Alison cita suas traduções dos contos da escritora brasileira, Lúcia Faro, nos quais, segundo a tradutora, há "vários momentos de muito estranhamento" e a sua opção foi por "recriar isso em inglês". Ela conclui esse comentário acerca de sua postura como tradutora dizendo que não foi sua intenção "passar um pano por cima e deixar tudo bonitinho, limpinho, mastigado" para o leitor da língua de chegada.

Ainda sobre essa questão, a tradutora menciona as traduções para o inglês do escritor alemão Kafka, feitas por um casal de australianos. Eles fizeram uma tradução "mais facilitadora, mastigada, fluente". O resultado disso foi um texto "muito mais fluente do que pretendia ser no alemão". E, segundo ela, as traduções mais recentes de Kafka estão sendo feitas na direção oposta, ou seja, tentando manter o estranhamento contido no original.

Sobre a influência que as teorias de tradução exercem sobre a sua prática tradutória, Alison não sabe dizer se é norteada por um determinado modelo teórico: "Eu não sei se tenho um paradigma teórico". Embora tenha lido muito sobre teoria de tradução literária no passado, atualmente ela não se dedica a esse tipo de leitura. Ela afirma aplicar "de uma forma muito mais inconsciente" toda a teoria por ela estudada e reitera o fato de ser norteada pela intenção do autor. Ela diz não fazer "nada sem ser pensado", sem refletir sobre suas opções, "mas não de forma muito teórica".

Quando o assunto é autoria, Alison destaca a importância de se reconhecer o papel do tradutor. Contudo, em sua opinião, "toda a realidade do livro é criada pelo autor do original". Ela afirma que seu trabalho não é criar essa realidade e sim transferir o conteúdo da obra: "Meu trabalho não é de 
criar, meu trabalho é de transpor, é linguísitico, é super criativo dentro de um parâmetro muito fixo, muito rígido." Tal parâmetro, segundo a tradutora, não é, nesse estágio, ditado pelo autor, mas pelo livro. No seu entendimento, ela não pode "fugir daquilo que foi pretendido originalmente" pelo autor.

Alison detém os direitos autorais de sua tradução de Budapeste. Contudo, a editora Bloomsbury pode fazer uso dessa tradução por um período pré-estabelecido pelo contrato: "[...] o copyright é meu e eu empresto para eles, para a publicação do livro". De acordo com informações fornecidas pela tradutora, uma vez esgotada a última edição do livro, se a editora deixar de publicar uma nova tiragem por um tempo determinado, os direitos de publicação voltam para ela. E a remuneração sobre a vendagem do livro só acontece quando ela ultrapassa certo patamar. Tal pagamento é feito como uma compensação - eventual royalty -, fato difícil de acontecer com traduções em países de língua inglesa, onde suas vendas são geralmente baixas.

Finalizando, Alison afirma que se divertiu muito com a tradução da obra Budapeste. Como exemplo "de coisas legais de traduzir", ela cita a marchinha de carnaval Allah-la $\hat{O}^{69}$, uma marca cultural inscrita no texto original que provocou hesitação na tradutora: "será que deixo, será que não deixo?". Fragmentos da letra da música apareciam pulverizados no texto que tinha como pano de fundo uma festa de Réveillon. Segundo Alison, "a graça toda é poder entender esses trechos da música e poder curtir essas coisinhas salpicadas no texto". Então, ela decidiu traduzir a música, tentando preservar as rimas, ritmo e número de sílabas. O resultado foi o seguinte: "Mas que calor ooô ooô..." como tradução de "So hot my Lord, o-0-0,0-0-0...". Concluindo,

\footnotetext{
${ }^{69}$ Composta por Haroldo Lobo e Nássara em 1941.
} 
disse que o leitor de língua inglesa ao ler essa tradução não saiba do que se trata. Contudo, a única maneira de "transmitir alguma coisa", ressalta a tradutora, seria construindo algo que rimasse. Afinal, trata-se de uma música popular.

\subsection{Liz Calder}

Liz Calder pode ser considerada a embaixadora da literatura brasileira na Inglaterra, onde lançou traduções de autores como Rubem Fonseca, Rui Castro, Paulo Lins, Milton Hatoum, Caetano Veloso e Chico Buarque. Iniciou a sua carreira trabalhando em editoras inglesas na década de 70 com Victor Gollancz; em seguida transferiu-se para Jonathan Cape, onde publicou o premiado Os filhos da meia noite, de Salman Rushdie. Em 1986, fundou, com mais três amigos, a Bloomsbury Publishing Plc, conhecida pelos seus escritores famosos, ganhadores de prêmios literários como Booker, Pulitzer, Whitbread e Prêmio Nobel, assim como pela publicação de Harry Potter. Além de responsável pelo maior festival britânico de literatura, em Hay-on-Wye, Calder é também idealizadora e presidente da Festa Literária Internacional de Parati (FLIP) desde a sua primeira edição em 2003.

A sua afinidade com a cultura brasileira surgiu na época em que residiu no Brasil com seu marido e filhos ainda pequenos: "Eu senti que pertencia a este lugar quando morei aqui na década de $60^{\prime 70} \mathrm{E}$ mesmo após o retorno ao seu país de origem, declarou nunca ter se esquecido do Brasil. Interessa-se pela literatura brasileira e acredita aprender mais sobre o Brasil com autores brasileiros do que pelos jornais e revistas.

70 "I felt I belonged here when I lived here in the 60's". Cabe reiterar que entrevista com Liz Calder foi realizada no Brasil, como mencionado na Introdução desta tese. 
De volta à Inglaterra, em 1968, Liz Calder começou a trabalhar em editoras inglesas, mas cansada do estilo "rígido" des1 desas instituições, pensou que seria mais interessante trabalhar em uma editora onde pudesse fazer tudo novo. Então, atendendo a um convite de Nigel Newton, fundou a Bloombury. Como parte das inovações dessa casa editorial, citou o fato de poder trabalhar mais próxima dos autores, dialogando com eles sobre suas obras e publicações como um todo, e.g. conteúdo, capa. Outro diferencial apontado por ela foi que, nos primeiros anos da criação da editora, os autores tinham uma participação sobre os lucros de seus livros, sempre que isso ocorresse; era algo que ia além dos direitos autorais.

Em suas palavras, os editores da Bloomsbury queriam que os autores se sentissem parte dessa nova concepção de editora. "Não era uma cooperativa, [...], mas era algo um pouco similar. Não poderíamos fazer isso em uma editora tradicional." ${ }^{, 72} \mathrm{O}$ terceiro traço diferenciador da Bloomsbury, com relação às editoras tradicionais britânicas, ressaltado por Liz Calder diz respeito à publicação de obras traduzidas para o inglês. Relata que sempre teve o desejo de publicar autores brasileiros, mas era difícil porque os editores não tinham interesse em publicar livros traduzidos, por serem mais caros e de autores cujos nomes eram desconhecidos pelo público. Após a fundação da Bloomsbury, isso tornou-se mais fácil, uma vez que era uma das proprietárias e tinha o poder de decisão.

Calder afirmou que seu nível de proficiência na língua portuguesa não era suficiente para explorar a linguagem literária e, portanto, para seleção dos autores brasileiros que deveriam ser publicados pela sua editora, teve a

\footnotetext{
71 "stiff"

72 "It wasn't a cooperative, [...], but it was something a little similar. We couldn't do that in a traditional publishing".
} 
assessoria do editor brasileiro Luiz Schwarcz, com quem se aconselhava e dava conselhos sobre livros: "[...] eu recebi muita ajuda e conselhos do [...] Luiz Schwarcz, [...] e tínhamos uma coisa recíproca. Eu falava com ele sobre livros, e ele falava comigo sobre livros brasileiros. ${ }^{73}$ Contava também com a opinião de tradutores, de outros leitores de língua portuguesa e com sua própria intuição antes de se decidir pela publicação de um livro.

A política editorial da Bloomsbury reflete fielmente o pensamento de sua co-fundadora, isto é, quando indagada sobre a importância de se publicar traduções de obras literárias oriundas de outras culturas, fora do âmbito europeu, ela foi enfática ao dizer que "É importante, é muito importante. Abre os olhos do leitor para o resto do mundo..74 Em sua opinião, "não se pode conhecer o mundo, se você não conhece a literatura mundial. ${ }^{75} \mathrm{~A}$ Bloomsbury publica traduções de muitas línguas, as do português brasileiro e do espanhol são, a maioria, seguidas das traduções do francês e do alemão que ocupam uma posição intermediária, informa Calder.

Ao responder sobre as vendagens dos livros brasileiros na Inglaterra, Calder afirmou que não se pode dizer que livros franceses, alemães ou de qualquer outro país vendem bem, "é sempre errado." ${ }^{\text {"6 }}$ falar isso. Como exemplo, citou o fato de ter sempre ouvido que livros escritos por indianos e livros sobre indianos não vendiam. No entanto, publicou o livro "Os filhos da meia noite,"77 de Salman Rushdie, que, como se sabe, foi um enorme sucesso editorial. Retomando o assunto sobre a vendagem de livros brasileiros no

\footnotetext{
73 "I had a lot of help and advice from, [...], Luiz Schwarcz, [ ], and we had a reciprocal thing. I would tell him about books, he would tell me about Brazilian books".

74 "It's important, it's very important. It opens the readers'eyes to the rest of the world."

75 "You cannot know about the world if you don't know of the world's literature."

76 "it's always wrong".

${ }^{77}$ Título original da obra: "Midnight's Children"
} 
exterior, Calder cita Paulo Coelho como exemplo de um brasileiro, cujos livros são bem vendidos. Então, para ela, esta questão "é irrelevante." 78

Ao comentar sobre a recepção de obras traduzidas pelo leitor inglês, afirma que tem havido mudanças de comportamento: "Eu acho que o público britânico melhorou no que diz respeito à aceitação do que chamamos nomes estrangeiros, em outras palavras, nomes que não são familiares."79 Antes diziam que era muito difícil, que não entendiam, "Mas agora existe uma aceitação muito maior"80, não só de tradução como também de literatura estrangeira.

Quanto à aceitação dos livros de Chico Buarque na Inglaterra, afirmou que sua notoriedade como cantor e compositor não influenciou na recepção de sua obra literária porque ele é muito pouco conhecido pelos ingleses. Ele foi reconhecido pela crítica especializada pelo seu talento como escritor, "ele sempre recebeu boas críticas." ${ }^{, 11} \mathrm{~A}$ forma como as traduções são resenhadas tem mudado na Inglaterra. Antes eram colocadas em uma seção separada, em um "gueto", agora não mais. O jornal britânico The Independent tem um interesse especial por traduções, publica boas resenhas, e até possui um prêmio para traduções, para o qual o autor Chico Buarque já foi inclusive indicado. Segundo Calder, isso é muito bom porque "eleva o perfil do escritor"82 e influencia nas vendas.

Sobre o perfil dos leitores ingleses, não só das obras de Chico Buarque, mas também de literatura traduzida no geral, Calder supõe que este público

\footnotetext{
78 "I think it's immaterial".

79 "I think the British public now is much better at accepting what we call foreign names, in other words, unfamiliar names."

80 "But now there is a much bigger acceptance, an acceptance of literature and translation".

81 "[...] he always got good reviews."

82 "[...] that lifts the author's profile."
} 
seja composto por pessoas que se interessam por acontecimentos fora da Inglaterra e da Europa, por pessoas que, provavelmente, já viveram em outros países e, talvez, sejam mais politizadas. Em resumo, o leitor do jornal britânico The Guardian talvez seja uma indicação do perfil do leitor de literatura traduzida na Inglaterra, acrescenta ela.

Calder discorda do tradutor e teórico da tradução, Lawrence Venuti (1995, p. 1), quando ele afirma que a maioria dos editores considera aceitáveis as traduções que sejam fluentes, ou seja, aquelas que causam no leitor a impressão de que foram originalmente produzidas na língua de chegada. $\mathrm{Na}$ opinião da editora, "o elemento importante em qualquer livro é a voz do autor"83, e a tradução deve captar tal voz, sob o risco de ser considerada insatisfatória, caso isso não ocorra.

Complementa sua fala dizendo que "isto é importante em uma tradução, dizer o que está no outro livro,"84 e que o tradutor, por sua vez, deve tentar captar a voz do autor, "ou uma voz bem similar"85 Como exemplo, menciona a tradução do romance Estorvo: "se soasse muito simples, não estaria, de modo algum, correta"86, ou seja, a tradução fluente de um enredo originalmente interrompido como o de Estorvo não seria adequada. Comentando sobre a tradução do romance Budapeste, ela ressalta a habilidade de Alison Entrekin em apreender a voz do autor, "eu achei que foi lindamente captada [...] a leitura foi muito fidedigna." 87

Os bons tradutores, de acordo com os critérios de Liz Calder, "devem ser capazes de escrever, de absorver e recriar a palavra, a voz, o personagem,

\footnotetext{
83 "[...] the important thing of any book is the voice of the author."

84 "..... that's the important thing in a translation, to say what is in the other book. [...]

85 "or some voice very similar"

86 "If it sound very simple, it wouldn't be at all right."

87 "I thought that was wonderfully captured, [...], it read very truth."
} 
o ritmo." ${ }^{88}$ Além dessas habilidades, afirma que o tradutor deve amar o seu ofício, pois não se trata apenas de um emprego. Para ela, a tradução de ficção é mais desafiadora e exige que o tradutor mergulhe no livro, e conclui dizendo que "admira muito os bons tradutores." 89

Ao falar sobre a participação de Chico Buarque em suas traduções para o inglês, Calder inicia seus comentários sobre o assunto destacando dois fatos, primeiro, a importância que as palavras têm para o autor ("As palavras são muito importantes para ele." ${ }^{\prime 90}$ ) e segundo, o fato de ele conhecer e gostar de outras línguas, o que permite que tenha acesso ao trabalho dos tradutores de suas obras. Calder ressalta que tal participação é muito importante para ele, assim como seria para "qualquer bom autor que se importasse com a linguagem, e com a linguagem de seu livro, gostaria de fazer o ele faz." "91 Até onde se sabe, nenhum outro escritor brasileiro participa das traduções de suas obras com a mesma intensidade que Chico Buarque.

Escritores como Milton Hatoum e Patrícia Melo se comunicam muito com seus tradutores, John Gledson e Clifford Landers, respectivamente. Mas, em sua opinião, o texto de Chico Buarque é mais intricado, metafórico e muito mais poético ("Ele parece mais um poeta [...] a tradução de poesia é muito, muito difícil"92 ) e, portanto, talvez, seja essa a razão de sua maior participação no processo tradutório. Calder complementa essa afirmação dizendo que "devido ao fato de saber exatamente o que está fazendo em português, ele quer ter o

\footnotetext{
88 "[...] they have to able to write, [...)] to absorb and recreate the word, the voice, the character, the rhythm"

89 "I admire good translators very much"

90 "Words matter to him greatly"

91 "[...] any good author, who cares about the language, and the language of the book, would want to do what he does"

92 "[...] he's more like a poet [...] translating poetry is very, very difficult."
} 
mesmo controle sobre as outras línguas." ${ }^{93}$ Chico Buarque é, nas palavras de Calder, "obsessivamente protetor"94 de seu texto, ou seja, não deixa escapar uma palavra que não esteja "completamente apurada" 95 ; ela reitera o fato de que o autor é impar no que diz respeito à escolha do léxico, pois "o cuidado e a importância de se conseguir a palavra certa é mais típico de um poeta do que de um romancista". ${ }^{96}$

Quando questionada se acreditava que Chico Buarque, na medida em que vem se tornando mais e mais traduzido, deixaria de dispensar tanta atenção às traduções de suas obras, ela respondeu que não pensa que ele deixará de se importar com elas, mas, acrescentou, que esse acompanhamento pode se tornar mais fácil se ele continuar trabalhando com tradutores já conhecidos dele.

Sobre a publicação da tradução para o inglês de "Leite Derramado", o último romance de Chico Buarque, Calder disse que estava sendo traduzido pela mesma tradutora de Budapeste, Alison Entrekin, e que será publicado pela editora Grove Atlantic Inc. Quando da realização desta conversa, em agosto de 2010, Calder informou que não faz mais parte do corpo de executivos da editora Bloomsbury, mas continua em contato com a editora, fazendo leituras e participando de alguns de seus eventos.

Finalizando, Liz Calder afirma que considera de praxe a participação do autor em suas traduções, "é de costume o tradutor ter um contato próximo com o autor, muito comum"97.

\footnotetext{
93 " [...] because he knows exactly what is doing in Portuguese, and he wants the same control on the other languages."

94 "obsessively protective"

95 "not absolutely accurate"

96 "The care and importance of getting it right is more like that of a poet than of a novelist"

97 "it is usual for the translator to liaise closely with the author, very common."
} 
No caso específico das traduções de Chico Buarque, Calder mencionou que o aspecto de sua obra que demanda mais atenção dos tradutores é, sem dúvida, "o vocabulário e a sutileza do modo como ele escreve."98

${ }^{98}$ The vocabulary and the subtlety of the way He writes. 


\section{CAPÍTULO III}

\section{A Linguística de Corpus e sua interface com a tradução}

\subsection{A Linguística de Corpus e as ferramentas computacionais utilizadas na análise dos corpora desta pesquisa}

A Linguística de Corpus $^{99}$, como definem Bowker \& Pearson (2002, p. 9), é uma metodologia ou abordagem empírica baseada no estudo de exemplos reais das linguagens escrita e oral. Tal abordagem faz uso abrangente de ferramentas computacionais para análise de um corpus. Por meio da aplicação desses recursos tecnológicos é possível observar não apenas padrões como divergências na norma em uma ou entre várias línguas.

Como observa Gonçalves (2008, p. 389): "A Linguística de Corpus vem sendo cada vez mais utilizada como um poderoso instrumento de pesquisa e observação do texto", e funciona como uma lente através da qual o pesquisador pode observar com maior visibilidade a presença de fenômenos linguísticos em determinado corpus ou em vários corpora, que dificilmente poderiam ser identificados a olho nu.

Nas palavras de McEnery \& Wilson (2001, p. 1), a LC já "começou a ampliar o seu escopo de atuação", 100 ela é um "sujeito vivo" e tem se tornado “multilíngue, com muitas línguas, e muitas variações dessas línguas, sendo estudadas com o auxílio de informações fornecidas por corpus"

\footnotetext{
${ }_{100}^{99}$ Doravante será usada a sigla LC para referir-se à Linguística de Corpus.

100 "has started to widen its scope"
} 
A LC é também usada como suporte metodológico e abordagem para o desenvolvimento de pesquisas em várias áreas do conhecimento, tais como lexicografia, ensino e aprendizagem de língua estrangeira, estudos da tradução, terminologia, sociolinguística, estudos culturais, dentre outras.

\subsection{A Linguística de Corpus é uma metodologia ou uma abordagem?}

Tem havido instigantes discussões acerca do atual status da LC. Kenny (2001) a define como "o ramo da linguística que estuda a linguagem com base nos corpora"101. Hoey (1977) afirma que a LC não é um ramo da linguística, mas o caminho para se chegar até ela, ou seja, a LC estabelece os parâmetros pelos quais visualizamos a linguagem. Para McEnery e Wilson (2001), a resposta da pergunta acima é positiva e negativa.

Segundo os autores, a LC não é um ramo da linguística como, por exemplo, a sociolinguística, a sintaxe e a semântica, "Todas essas disciplinas concentram-se na descrição e/ou explicação de algum aspecto do uso de uma língua"102, enquanto "A LC, ao contrário, é uma metodologia, e não um aspecto linguístico que requer explicação ou descrição" ${ }^{\text {"103 }}$. As disciplinas acima citadas são algumas das áreas de pesquisa linguística que utilizam uma abordagem baseada em corpus. Portanto, os autores afirmam que a LC "é uma metodologia que pode ser utilizada em quase todas as áreas da linguística, mas, de fato, não delimita em si uma área da linguística ${ }^{104}$."

\footnotetext{
101 "Corpus linguistics is the branch of linguistics that studies language on the basis of corpora" 102 "All these disciplines concentrate on describing/explaining some aspect of language use."

103 "Corpus Linguistics in contrast is a methodology rather than an aspect of language requiring explanation or description".

${ }_{104}$ "Corpus Linguistics is a methodology that may be used in almost any area of linguistics, but it does not truly delimit an area of linguistics itself."
} 
Por outro lado, os autores defendem a opinião de que a LC define um ou mais terrenos próprios nos domínios da linguística geral uma vez que "nos permite estabelecer diferenças entre as abordagens utilizadas no estudo da linguagem". Como exemplos disso, citam os estudos da semântica e da sintaxe baseados em corpus em oposição à semântica e à sintaxe tradicionais, não baseadas em corpus. Concluindo, McEnery \& Wilson afirmam que embora a LC não constitua uma área de investigação linguística em si própria, "ela, pelo menos, nos permite estabelecer diferenças entre abordagens metodológicas utilizadas em uma mesma área de pesquisa por diferentes grupos, indivíduos ou estudos". ${ }^{105}$ (2001, p. 2)

Tendo dito isso, pode-se afirmar que a LC é uma das áreas mais profícuas e efervescentes no que diz respeito ao estudo da linguagem. Como afirma Beber Sardinha, ela "não se resume a um conjunto de ferramentas" (2004, p. 36), e tampouco pode ser rotulada de "contabilidade linguística" (2004, p. 43). Ela deve, de fato, ser considerada uma abordagem na medida em que os pesquisadores que dela se utilizam, como base metodológica, para realizar suas investigações acabam produzindo novos conhecimentos. A LC, além de comprovar ou contestar hipóteses intuitivas acerca de eventos linguísticos, pode revelar fatos de determinado corpus que não se imaginava antes.

\footnotetext{
105 "[...] it does, at least, allow us to discriminate between methodological approaches taken to the same area of enquiry by different groups, individuals or studies."
} 


\section{3. $O$ que é um corpus?}

No domínio da LC o significado da palavra corpus vai além de um "conjunto de documentos, dados e informações sobre determinada matéria" ${ }^{106}$. Neste contexto, explica Tagnin (2005:22): "um corpus é uma coletânea de textos, necessariamente em formato eletrônico, compilados e organizados segundo critérios ditados pelo objetivo de pesquisa a que se destina." No que concerne ao seu propósito, o corpus "deve ter a finalidade de ser um objeto de estudo linguístico" (BERBER SARDINHA, 2004, p. 18).

Bowker e Pearson (2002, p. 9-10) ressaltam as principais características que diferem os corpora no âmbito da LC de outros tipos de coletâneas de textos: a) eles devem ser constituídos de textos autênticos, ou seja, os textos não podem ter sofrido alterações visando fins específicos; b) os textos necessitam estar em formato eletrônico, originalmente ou escaneados e posteriormente gravados em formato texto ( ${ }^{*}$.txt) para que possam ser reconhecidos e processados por ferramentas computacionais; c) o volume dos textos que compõem o corpus deve ser extenso o bastante para justificar a utilização de recursos computacionais para exploração de seus conteúdos; d) o corpus deve ser organizado de acordo com o objetivo da pesquisa. Portanto, uma coletânea aleatória de textos sem objetivos definidos não constitui um corpus no sentido estrito da LC.

${ }^{106}$ Como define o Novo Dicionário Aurélio da Língua Portuguesa. 


\subsection{Os diferentes tipos de corpora}

Devido ao caráter dinâmico da linguagem, um corpus, por maior e mais abrangente que seja, não pode ser usado como único e legítimo representante de determinada língua, pois possui os seus limites. Diferentes tipos de corpora podem ser projetados para se adequarem aos propósitos de determinada investigação. Como exemplo, cito o caso desta pesquisa, para a qual foram construídos dois corpora: o primeiro constituído pelas três obras literárias do escritor Chico Buarque de Holanda, a saber, Estorvo, Benjamim, e Budapeste; o segundo composto pelas suas respectivas traduções para a língua inglesa, ambos para atenderem ao propósito de se investigar as estratégias de traduções adotadas pelos tradutores em determinadas situações, por meio da comparação entre eles. Os procedimentos de compilação dos aludidos corpora e suas características serão detalhados no capítulo referente à metodologia da pesquisa.

Mesmo diante da possibilidade de se constituir inúmeros tipos de corpora, é possível estabelecer uma categorização. Os tipos de corpora apresentados a seguir são aqueles propostos por Bowker e Pearson (2002, p.11):

Corpus Geral de Referência pode ser considerado representativo de determinada língua; pode, portanto, ser usado para se fazer observações gerais sobre essa língua em particular. Esse tipo de corpus costuma contemplar as linguagens escrita e falada, sendo também composto por uma variedade de gêneros textuais, tais como textos jornalísticos, literários, acadêmicos, técnicos, científicos etc. 
Essa categoria de corpus é geralmente de porte grande ${ }^{107}$, uma vez que, segundo Berber Sardinha (2004, p.22), "A característica mais facilmente associada à representatividade é justamente a extensão do corpus, o que significa, em termos simples, que para ter representatividade o corpus deve ser o maior possível" Como exemplos de corpora dessa natureza têm-se, dentre outros de língua portuguesa, o Banco de Português com 233 milhões de palavras, o Corpus Brasileiro ${ }^{108} \mathrm{com}$ um bilhão de palavras do português brasileiro contemporâneo escrito e falado e o Corpus do Português ${ }^{109}$ com 45 milhões de palavras. Em língua inglesa, pode-se iniciar a citação, dentre os vários disponíveis, com o pioneiro Brown Corpus ${ }^{110}$, lançado em 1964, com um milhão de palavras, passando pelo BNC (British National Corpus), que o foi o primeiro a conter cem milhões de palavras e chegando ao The Corpus of Contemporary American English - $\operatorname{COCA}^{111}$, com quatrocentos milhões de palavras.

Corpus para fins específicos, como o próprio nome diz, foca em um aspecto especial de determinada língua. Esse tipo de corpus é também chamado de "especializado" (BERBER SARDINHA, 2004, p. 21). Ele pode ser restrito a determinada área do conhecimento (ex. jurídica), a um gênero textual específico (ex. jornalístico), a um tipo de variação linguística ou à linguagem usada pelos membros de determinado grupo demográfico (ex. adolescentes, moradores das favelas no Rio de Janeiro). Ao contrário do corpus geral, o

\footnotetext{
${ }^{107}$ Nesse estudo, entende-se por corpus grande aquele que, segundo classificação de Berber Sardinha (2002, p.26), possui 10 milhões de palavras ou mais.

${ }_{108} \mathrm{O}$ corpus pode ser acessado pelo site http://corpusbrasileiro.pucsp.br/x/.

$109 \mathrm{O}$ corpus pode ser acessado pelo site http://davies-linguistics.byu.edu/personal/

${ }^{110}$ Embora o Brown Corpus possua apenas um milhão de palavras, foi o pioneiro de língua inglesa, e durante muito tempo serviu de referência para muitos estudos realizados por linguistas de corpus.

${ }^{111} \mathrm{O}$ corpus pode ser acessado pelo site http://www.americancorpus.org/.
} 
corpus para fins específicos, devido à sua característica especializada, não pode ser usado para se fazer observações sobre a linguagem em geral.

Os corpora denominados geral e para fins específicos ou especializado podem ser também usados de forma comparativa com 0 objetivo de se identificar características particulares da linguagem especializada com relação à linguagem geral. Nesse caso, o corpus geral passa ser usado como corpus de referência, também chamado de corpus de controle, cuja função primordial é oferecer um padrão de comparação com o corpus especializado que se pretende investigar, chamado, então, de corpus de estudo. Tal comparação é feita automaticamente por uma ferramenta computacional que compara as listas de palavras dos corpora de referência e de estudo, gerando uma lista de palavras-chave. Esse procedimento será detalhado ainda neste capítulo quando da descrição do uso do software WordSmith Tools e de seus aplicativos WordList e KeyWords.

Corpus escrito e Corpus falado: O corpus escrito é formado por textos produzidos originalmente no formato escrito, enquanto o corpus falado é constituído de transcrições de textos originalmente falados, como palestras, entrevistas, textos televisivos e radiofônicos. O Corpus Brasileiro e The Corpus of Contemporary American English - COCA, citados anteriormente, são exemplos de corpora compostos por textos escritos e falados. Pretende-se, futuramente, transformar as entrevistas que fazem parte desta tese de doutorado, mencionadas na introdução, em um corpus falado, para que possa servir de fonte de pesquisa para outros pesquisadores.

Corpus sincrônico e Corpus diacrônico: O corpus sincrônico abrange um período de tempo, oferecendo um panorama da linguagem utilizada 
naquele período determinado, ao passo que o corpus diacrônico engloba vários períodos de tempo, podendo ser usado para se estudar a evolução de uma língua dentro de uma determinada época. (Corpus de Português (diacrônico) VS Corpus Brasileiro, ambos usados nesta pesquisa como corpora de pesquisa, são exemplos desses tipos de corpora.)

Corpus aberto e Corpus fechado: O corpus aberto é aquele que está em constante expansão. Como aponta Bowker (2002, p. 13), esse tipo de corpus é comumente utilizado por lexicógrafos devido à sua natureza dinâmica e atual. O corpus The Bank of English ${ }^{112}$, da editora Collins Cobuild, assim como o COMET (Corpus Multilíngue para Ensino de Tradução) ${ }^{113}$ e os já citados corpora: The Corpus of Contemporary American English - COCA e o Corpus Brasileiro são alguns exemplos de corpora abertos. O corpus fechado é aquele que não aceita acréscimos após a sua compilação, como exemplo, o Brown Corpus e o Banco de Português, o CR-LW (Corpus de referência LácioWeb) ${ }^{114}$.

Corpus monolíngue e Corpus multilíngue: $O$ corpus monolíngue, como o próprio nome indica, é composto por textos em uma única língua. Segundo Laviosa (1997), o corpus monolíngue pode ser composto por textos originalmente escritos em determinada língua (e.g. os corpora Brown e BNC, ou por uma coletânea de textos traduzidos para aquela língua (ex.. Translational English Corpus, TEC).

O corpus multilíngue contém textos em duas ou mais línguas. Bowker (2002) subdivide os corpora multilíngues em duas categorias: comparável e paralelo. O corpus comparável é constituído de textos em mais de uma

\footnotetext{
${ }^{112} \mathrm{O}$ corpus pode ser acessado pelo site http://www.cobuild.collins.co.uk/boe_info.html

${ }_{113} \mathrm{O}$ corpus pode ser acessado pelo site http://www.fflch.usp.br/dlm/comet/

${ }^{114} \mathrm{O}$ corpus pode ser acessado pelo site http://www.nilc.icmc.usp.br/lacioweb/
} 
língua, contudo não são traduções entre si; são textos selecionados para compor o corpus com base nas características que possuem em comum, por exemplo, o mesmo assunto ou o mesmo gênero textual. Um corpus formado por resumos de textos acadêmicos em diferentes línguas ou uma coletânea de textos jornalísticos oriundos de diferentes jornais estrangeiros sobre 0 ataque terrorista em onze de setembro de 2001 nos Estados Unidos podem ser exemplos desse tipo de corpus.

O corpus paralelo, por sua vez, pode ser multilíngue ou bilíngue. $O$ corpus paralelo multilíngue é formado por textos originais e suas respectivas traduções para mais de uma língua. Um exemplo desse tipo de corpus pode ser um corpus compilado pelos romances originais do autor Chico Buarque e suas respectivas traduções para mais de um idioma. Esse tipo de corpus possibilitaria ao pesquisador desenvolver, por exemplo, um estudo contrastivo entre as estratégias de traduções adotadas pelos tradutores de diferentes línguas e culturas da mesma obra original.

O corpus paralelo bilíngue é formado por textos originais e suas respectivas traduções. No que concerne ao seu uso, o corpus paralelo representa uma fonte valiosa de informações para tradutores profissionais, pesquisadores na área de estudo tradutológicos, professores e aprendizes de tradução e de línguas estrangeiras, assim como para terminólogos e lexicógrafos.

Outro uso do corpus paralelo é ressaltado por Bowker (2002, p. 209). Segundo a autora, ele pode ser usado quase que nos mesmos moldes de um dicionário bilíngue, com a vantagem de oferecer mais informações sobre estilo de linguagem e colocações que o dicionário convencional geralmente traz. $O$ 
corpus desta pesquisa de doutorado é um exemplo de corpus paralelo bilíngue, uma vez que é composto pelas já mencionadas obras originais em português e suas respectivas traduções para o inglês.

Uma vez compilado o referido corpus de estudo desta pesquisa, fez-se uso do programa computacional WordSmith Tools para ajudar na investigação do corpus, o qual passa a ser descrito.

\subsection{O programa para a análise de dados - WordSmith Tools}

O programa selecionado para esta pesquisa foi o WordSmith Tools, versão 5, desenvolvido por Mike Scott ${ }^{115}$. O WordSmith possibilita, entre outras ações, a obtenção de listas de palavras de todo o corpus de estudo, em ordem alfabética e de frequência. Esse programa também disponibiliza dados estatísticos sobre o corpus da pesquisa: o número de palavras no texto (tokens), o número de palavras distintas nos texto (types), a razão tokenstypes, o tamanho do corpus em bytes e outros dados relacionados com a composição lexical e estrutural do texto.

As cinco versões do WordSmith Tools possuem as ferramentas: WordList, KeyWords, Concord, e os utilitários: FileManager, Splitter, Text Converter, e Viewer and Aligner. Para a investigação de nossos corpora, utilizamos as seguintes ferramentas:

- WordList, que possibilita obter o cômputo total das palavras no texto (tokens), o número de palavras distintas no texto (types), o número total de

\footnotetext{
${ }^{115}$ O program WST é comercializado pela Oxford University Press. Ele pode ser obtido pela internet, no endereço http://www.lexically.net/downloads/download.htm, ou acessando http://www.lexically.net.
} 
frases e as listas de palavras dos dois corpora em ordem alfabética e de frequência, enfim, uma verdadeira radiografia do texto.

A figura 1 abaixo mostra os trinta primeiros vocábulos (tradução usada por Berber Sardinha (1990) para o termo type) de nosso corpus de estudo em português. A primeira coluna mostra a ordem de classificação desses vocábulos de acordo com a sua frequência no corpus, a segunda coluna relaciona os vocábulos do referido corpus. Como é de praxe, os vocábulos mais frequentes são palavras gramaticais, tais como: artigos (a, as, o, um); preposições (de, em, com); conjunções (e, mas); pronomes (me, eu, ela, ele, meu). A terceira coluna mostra a frequência absoluta desses vocábulos no corpus, ou seja, quantas vezes a palavra ocorreu e a quarta coluna a sua frequência percentual, que corresponde à percentagem do total de palavras do texto. Há 4.222 ocorrências do vocábulo de (frequência absoluta) no corpus de estudo português original, o que significa que ele representa 3,77\% (frequência percentual) de todos os itens (tradução usada por Berber Sardinha (1990) para o termo tokens) presentes no referido corpus. 


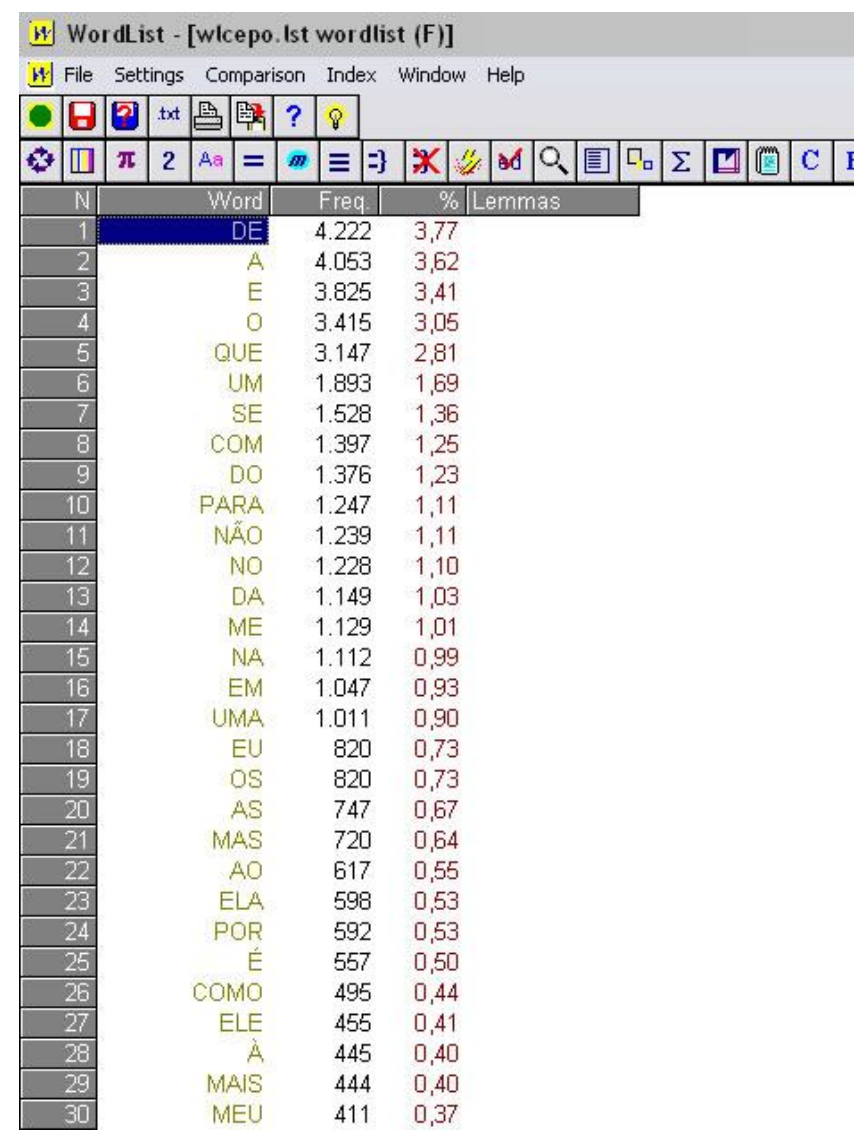

Figura 1 - Trinta primeiros vocábulos do Corpus de Estudo Português Original.

- KeyWords, que fornece a seleção de palavras-chave por meio da comparação automática de dois corpora: geralmente um corpus de estudo (menor e mais especializado) com um corpus de referência (maior e mais geral) e relaciona as palavras-chave do corpus mais especializado, ou seja, do corpus de estudo. O corpus de estudo, representado por uma lista de frequência de palavras gerada a partir do corpus ou dos corpora que se pretende descrever, é comparado com o corpus de referência, também formatado como uma lista de frequência de palavras.

O resultado dessa comparação pode mostrar, por exemplo, as palavraschave, ou seja, aquelas que aparecem com uma alta frequência no corpus de estudo, não necessariamente em termos absolutos, mas que aparecem com 
uma frequência incomum se comparadas às palavras do corpus de referência (BOWKER, 2002: 167). As palavras-chave são classificadas de acordo com o seu nível de chavicidade, ou seja, "o grau de destaque das palavras no sentido de serem anormalmente frequentes no corpus de estudo em relação ao corpus de referência." (GERBER, 2007).

Segundo Berber Sardinha (2004, p. 102), "o tamanho recomendado de um corpus de referência é cinco vezes o tamanho do corpus de estudo" porque retornam mais palavras-chave do que aqueles de menores dimensões.

A figura 2, a seguir, mostra as trinta primeiras palavras-chave geradas pela comparação da lista de palavras do Corpus de Estudo em Português Original, (que na tabela aparece com o nome de EPO.LST) com a lista de palavras do Corpus de Referência Banco de Português (que na tabela aparece com o nome de PO3.LST). A coluna $\mathrm{N}$ mostra a ordem de classificação desses vocábulos de acordo com a sua chavicidade no corpus.

A coluna WORD é composta pelas palavras consideradas "chave"; a coluna FREQ. informa a frequência absoluta da palavra no corpus de estudo; a coluna EPO.LST \% traz a frequência percentual da palavra, ou seja, a porcentagem da palavra em relação ao total do corpus de estudo; a coluna FREQ. mostra a frequência absoluta da palavra-chave no corpus de referência; a coluna PO3.LST\% indica a porcentagem da palavra-chave com relação ao total do corpus de referência; a coluna KEYNESS refere-se à chavicidade da palavra, ou seja, o resultado da estatística de comparação entre os corpora de estudo e o de referência e a coluna P contém o valor da significância atingido pelo resultado da estatística. 


\begin{tabular}{|c|c|c|c|c|c|c|c|c|c|c|}
\hline \multicolumn{11}{|c|}{$\sigma_{\mathfrak{h}}$ KeyWords - [kwcepo3.kws (keyness)] } \\
\hline \multicolumn{11}{|c|}{$\sigma_{\tilde{R}}^{*}$ Flle settings Window Help } \\
\hline - & 口曰 & t.xt 目 & 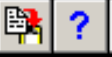 & 8 & & & & & & \\
\hline$\geqslant$ & \begin{tabular}{|l|l|}
$\square$ & $\pi$ \\
\end{tabular} & Aa $=$ & ; & 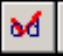 & Q & 디 浐 & $\mathrm{C}$ & \begin{tabular}{|l|l} 
W & F \\
\end{tabular} & \\
\hline \multirow{2}{*}{$\frac{N}{1}$} & & WORD & TFREQ & \multicolumn{2}{|c|}{$\overline{E P O L S T \%}$} & $\overline{\text { FREQ }}$ & \multicolumn{2}{|c|}{ P03.LST \% } & \multirow{2}{*}{$\frac{\text { KEYNESS }}{5.240,1}$} & $\mathrm{P}$ \\
\hline & & ARIELA & 361 & & 0,32 & 42 & & & & 0,000000 \\
\hline 2 & & ENJAMMIM & 408 & & 0,36 & 410 & & & $5.093,3$ & 0,000000 \\
\hline 3 & & ME & 1.129 & & 1,011 & 131.587 & & 0,06 & $4.352,8$ & 0,000000 \\
\hline 4 & & KRISKA & 130 & & 0,12 & 2 & & & $1.963,0$ & 0,000000 \\
\hline 5 & & VANDA & $(6)$ & & 0,14 & 321 & & & $1.843,1$ & 0,000000 \\
\hline 5 & & EU & 820 & & 0,732 & 248.174 & & 0,11 & $1.746,2$ & 0,000000 \\
\hline 7 & & ASTANA & 95 & & 0,08 & 10 & & & $1.383,6$ & 0,000000 \\
\hline 8 & & MEU & $4 \%$ & & 0,37 & 74.920 & & 0,03 & $1.242,1$ & 0,000000 \\
\hline 9 & & ELA & 598 & & 0,531 & 188.953 & & 0,08 & $1.228,9$ & 0,000000 \\
\hline 10 & & MINHA & 390 & & 0,35 & 70.989 & & 0,03 & $1.179,6$ & 0,000000 \\
\hline 11 & & LHE & 294 & & 0,26 & 45.259 & & 0,02 & 979,2 & 0,000000 \\
\hline 12 & & YANDRO & 65 & & 0,06 & 3 & & & 967,2 & 0,000000 \\
\hline 13 & & AMBRAIA & 59 & & 0,05 & 7 & & & 855,6 & 0,000000 \\
\hline 14 & & UM & 1.893 & & 1,69 & 03.447 & & 0,83 & 781,9 & 0,000000 \\
\hline 15 & & PORTA & 219 & & 0,20 & 31.994 & & 0,01 & 750,5 & 0,000000 \\
\hline 16 & & ÂMBOLO & 47 & & 0,04 & 0 & & & 717,2 & 0,000000 \\
\hline 17 & & OLHOS & 173 & & 0,15 & 17.275 & & & 716,1 & 0,000000 \\
\hline 18 & & SE & 1.528 & & 1,36 & 59.885 & & 0,63 & 712,0 & 0,000000 \\
\hline 19 & & ROSTO & 132 & & 0,12 & 8.637 & & & 652,9 & 0,000000 \\
\hline 20 & & $E$ & 3.820 & & 3,41 & 20.476 & & 2,22 & 629,9 & 0,000000 \\
\hline 21 & & CAMA & 116 & & 0,10 & 6.217 & & & 618,3 & 0,000000 \\
\hline 22 & & BEATRIZ & 95 & & 0,08 & 3.062 & & & 599,8 & 0,000000 \\
\hline 23 & & MALA & 88 & & 0,08 & 2.266 & & & 593,9 & 0,000000 \\
\hline 24 & & MÁO & 197 & & 0,18 & 36.402 & & 0,02 & 590,2 & 0,000000 \\
\hline 25 & & JEOVAN & 39 & & 0,03 & 2 & & & 579,1 & 0,000000 \\
\hline 26 & & ZORZA & 39 & & 0,03 & 2 & & & 579,1 & 0,000000 \\
\hline 27 & & KÓSTA & 32 & & 0,03 & 0 & & & 488,3 & 0,000000 \\
\hline 28 & & AGRINHA & 39 & & 0,03 & 55 & & & 467,6 & 0,000000 \\
\hline 29 & & ERA & 398 & & 0,302 & 220.212 & & 0,10 & 463,5 & 0,000000 \\
\hline 30 & & BOCA & 123 & & 0,11 & 16.108 & & & 446,4 & 0,000000 \\
\hline
\end{tabular}

Figura 2 - Trinta primeiras palavras-chave do Corpus de Estudo Português Original.

A ferramenta KeyWord oferece a opção de dois tipos de testes estatísticos para se calcular a chavicidade das palavras: o qui-quadrado e o log-likelihood. Nesta pesquisa, utilizou-se como fórmula estatística o loglikelihood porque ele é usado para comparar listas de palavras de grandes tamanhos, informa Gerber (2007, p.89). O valor de $\boldsymbol{p}$ utilizado nesta pesquisa foi 0,001 , isso significa que há $0,1 \%$, o que representa um caso em mil, de probabilidade de o resultado ser devido ao acaso. Um percentual bastante seguro, pois na área de "Ciências Sociais, $5 \%$ de risco é um resultado 
considerado aceitável”. A frequência mínima foi estipulada em 10 ocorrências.

Quanto ao índice de chavicidade, apenas as palavras com índice superior a 50 seriam candidatas à análise, a delimitação do escopo da análise fez com que se optasse por esse índice. De acordo com o manual de informação do programa WST (SCOTT,1998), índices de chavicidade acima de 4,0 são considerados significativos.

A figura 3 abaixo mostra a tela do setting contendo as configurações que foram utilizadas para gerar as listas de palavras-chave.

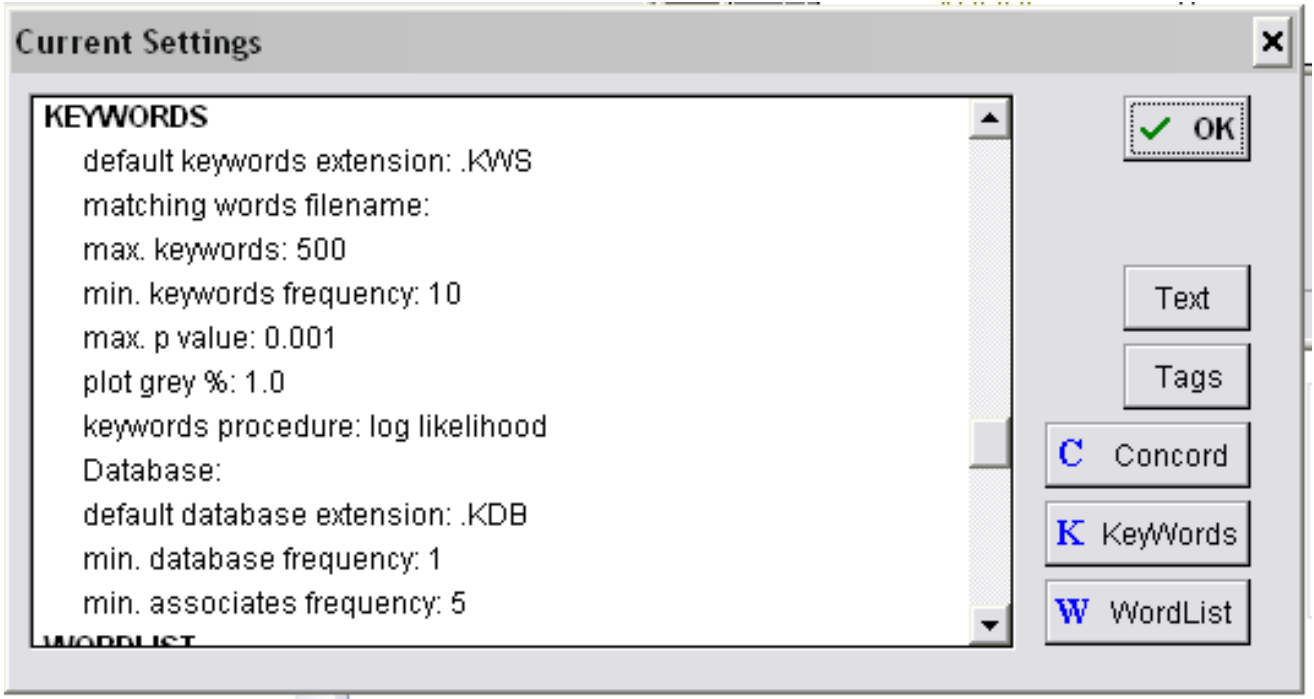

Figura 3 - Tela do Setting KEYWORDS 


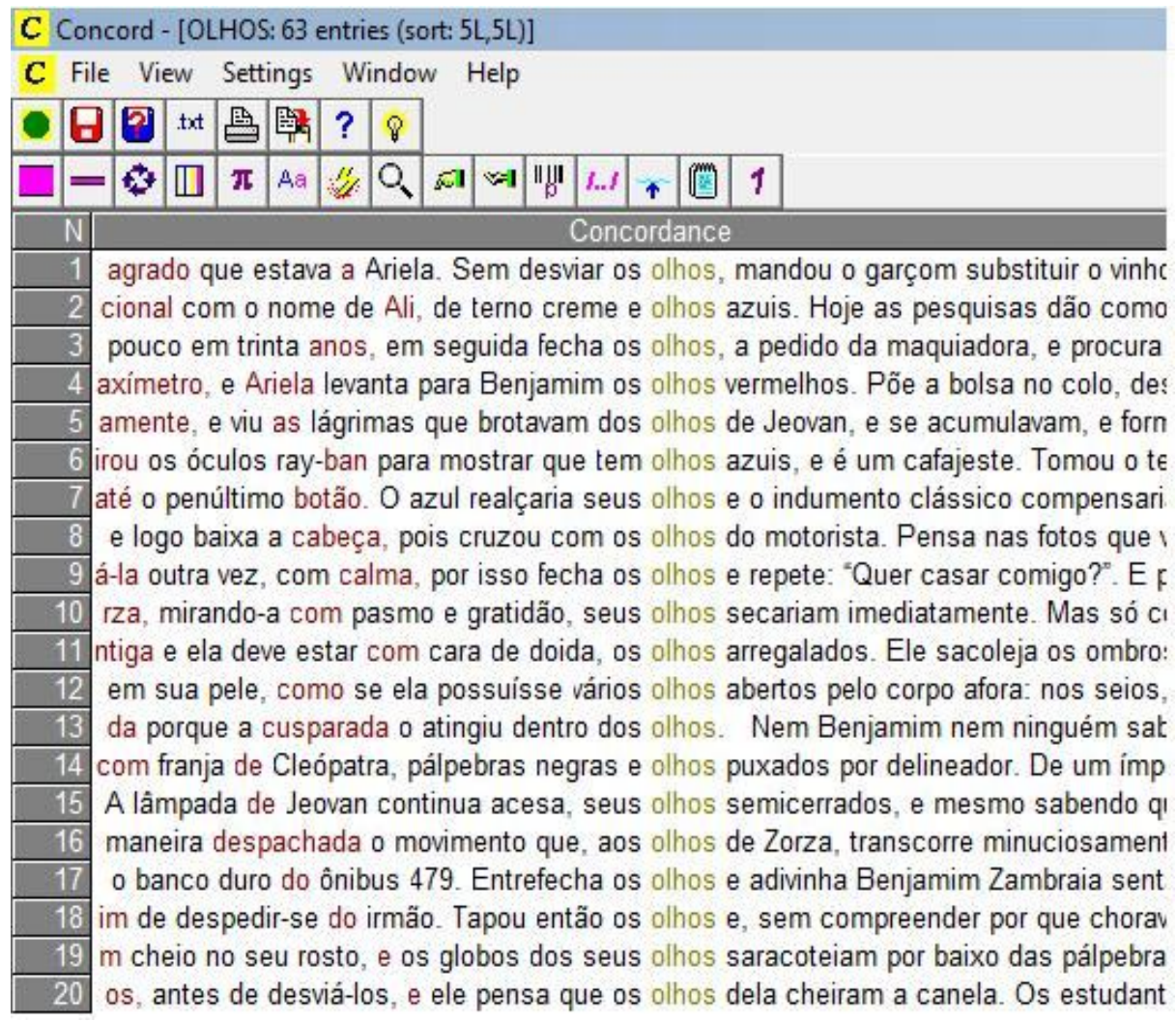

Figura 4 - Concordance da palavra de busca "olhos" do corpus de estudo português original.

O Concord, que produz concordâncias ou listas de ocorrências de uma palavra ou frase escolhida pelo pesquisador. O item selecionado é denominado palavra de busca ou nódulo. A palavra de busca vem acompanhada de um texto cujo escopo é estipulado pelo pesquisador. Os tipos de concordância variam de acordo com a posição da palavra de busca, a mais comum é a $K W I C$ (Key Word in Context), em que a palavra de busca aparece na posição central da linha de concordância e é acompanhada do co-texto anterior e posterior a ela. É, também, possível organizar a busca de uma palavra específica ordenando alfabeticamente as palavras anteriores ou posteriores à palavra de busca. Essa ferramenta também informa o número total de ocorrências da palavra de busca no texto. A figura 4 abaixo mostra uma concordância da palavra de busca "olhos" que faz parte do Corpus de Estudo em Português Original. 
O programa WST (WordSmith Tools) oferece, por meio do utilitário

Viewer and Aligner, a possibilidade de alinhar os textos original e traduzido. $O$ alinhamento permite visualizar as sentenças ou parágrafos dos textos original e traduzido de forma alternada. Essa visualização, apesar de clara, não pode ser feita lado a lado. A figura 5 abaixo apresenta o resultado desse alinhamento:

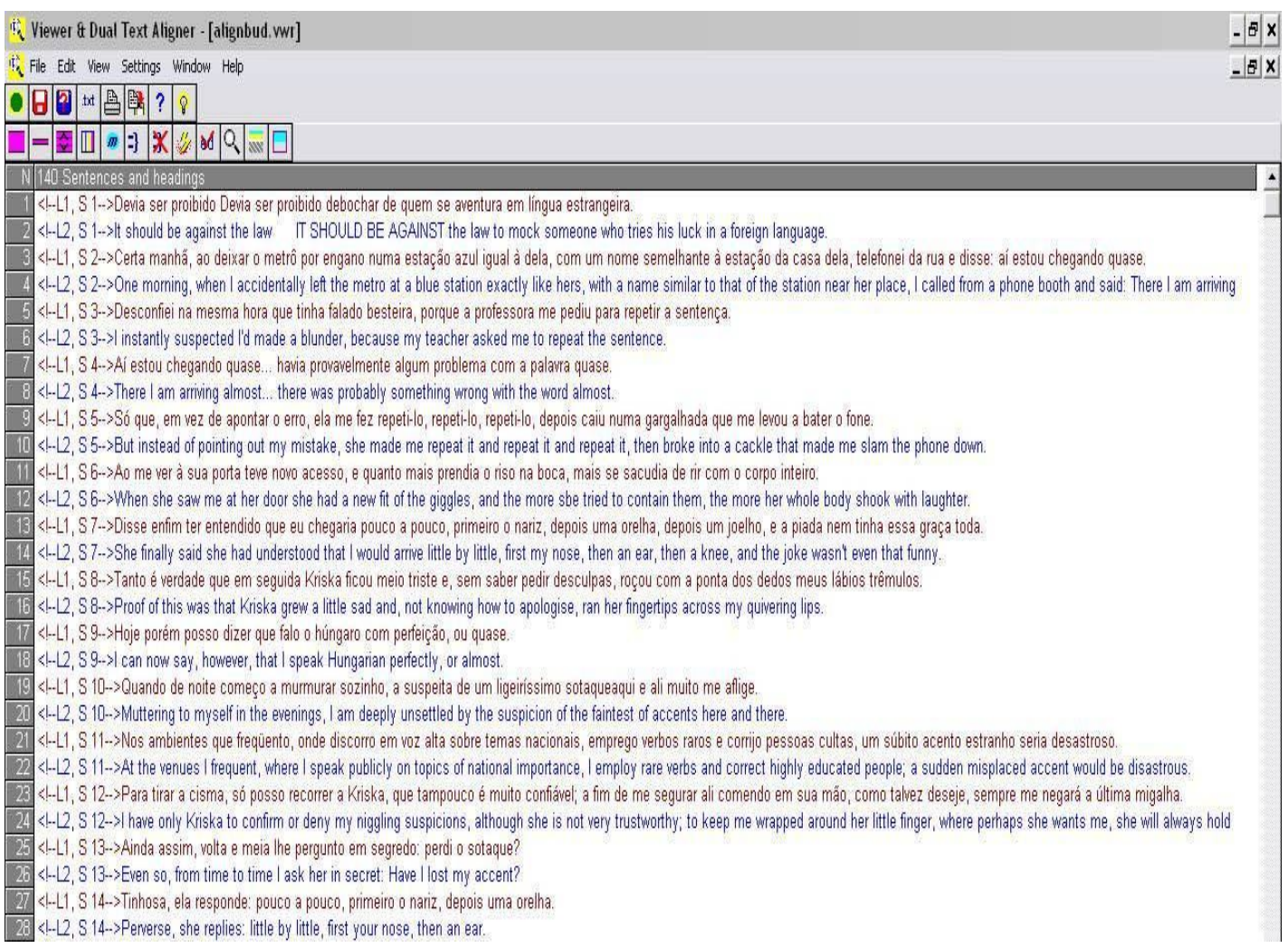

Figura 5 - Alinhamento dos textos original e traduzido do romance Budapeste.

\subsection{O software ParaConc}

Mesmo diante da possibilidade de alinhamento oferecida pelo programa WST, optou-se pelo uso da ferramenta ParaConc: Concordance software for multilingual parallel corpora, de Michael Barlow, para alinhar os textos originais e traduzidos, porque ela oferece um tipo de visualização que se julga facilitar o cotejo entre os textos original e traduzido, pois esses textos ficam lado a lado. Além disso, oferece a opção Parallel Search, um sistema de busca feito sob 
medida para ser usado com textos paralelos. Esse tipo de busca, ilustrado na figura 6 abaixo, permite ao pesquisador restringir a busca de uma ou mais palavras que ocorrem nos textos paralelos.

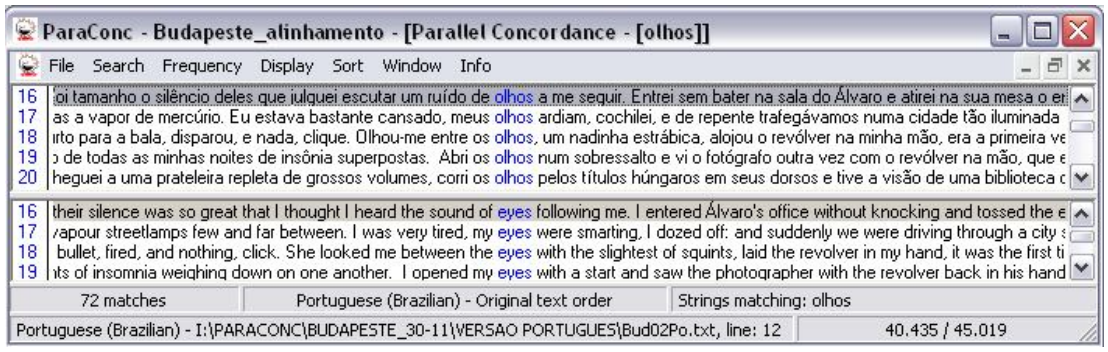

Figura 6 - Resultado parcial do Parallel Search com as palavras "olhos" e "eyes" nos corpora paralelos, compostos pelos textos originais e traduzidos do romance Budapeste.

Com o software ParaConc é possível fazer vários tipos de pesquisas com textos traduzidos, desde a análise de terminologia e fraseologia bilingues, até o estudo de três traduções diferentes de um único texto original. No caso desta pesquisa, pretende-se identificar, por meio do cotejo entre textos original e traduzido, as possíveis estratégias utilizadas pelos tradutores das obras literárias de Chico Buarque.

O processo de alinhamento é fundamental para que a operação executada pelo ParaConc seja bem sucedida, pois quando o programa faz uma busca no texto original, o alinhamento é a única fonte de informação que o programa possui sobre as relações entre as diferentes línguas. A figura 7 abaixo ilustra o alinhamento dos textos original e traduzido. 


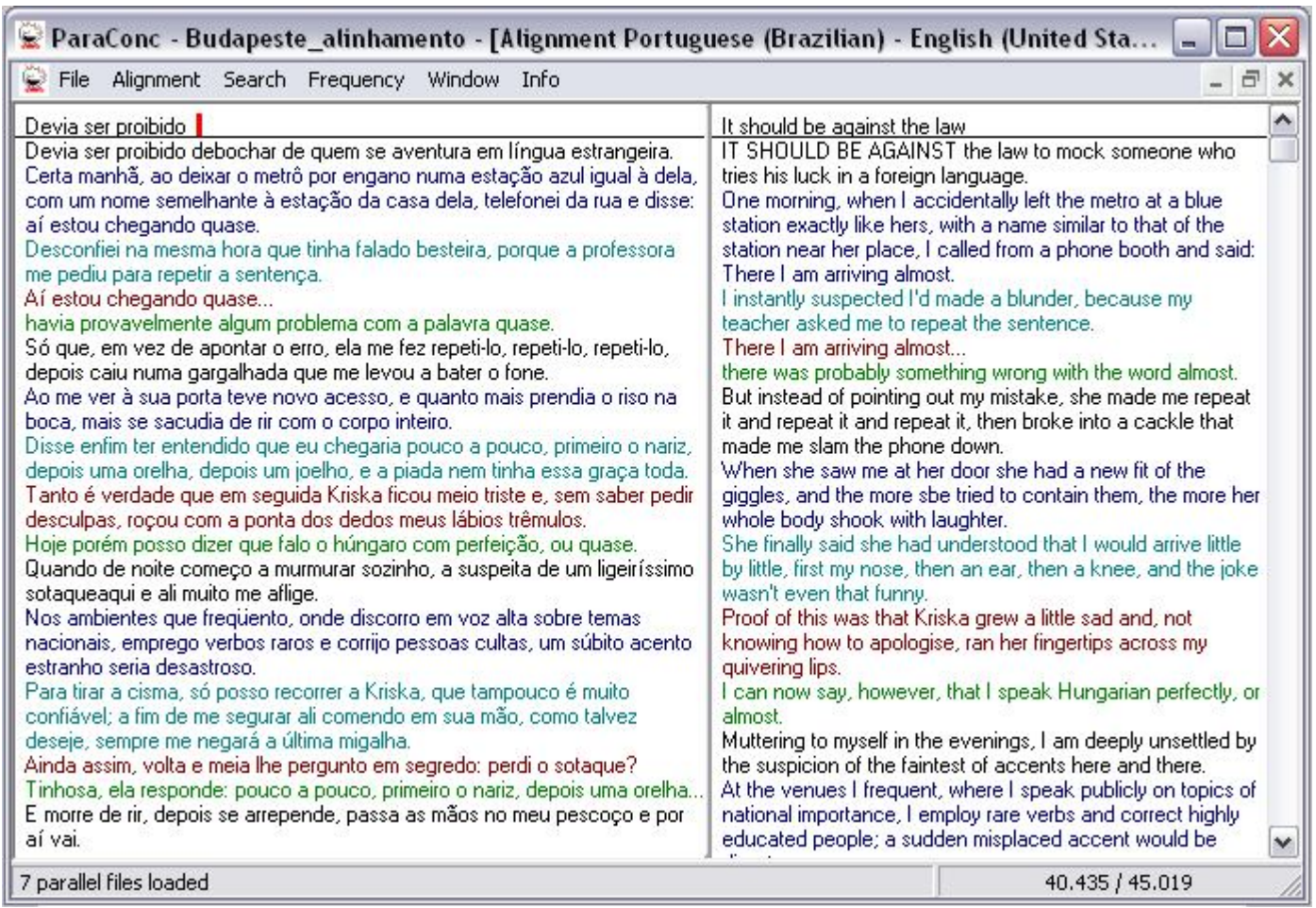

Figura 7 - Alinhamento feito com o software ParaConc de parte do primeiro capítulo do romance Budapeste nas versões original e traduzida.

É possível observar pela visualização da figura acima, que o alinhamento que representa uma equivalência entre os segmentos do texto original e do texto traduzido, é feito sentença por sentença. Contudo, não existe sempre uma correspondência precisa entre esses alinhamentos porque, por exemplo, ao longo do texto, uma sentença do texto de partida pode ser equivalente a duas ou mais sentenças no texto de chegada, podendo ocorrer também omissões e simplificações que comprometam essa precisão, exigindo uma série de ajustes manuais para que se tenha um alinhamento paralelo adequado em blocos de sentenças, e não sentença por sentença. 


\subsection{A convencionalidade}

Partindo do pressuposto de que convencional, em sua acepção mais ampla no Aurélio (1986, p.470) é tudo aquilo "consagrado e aprovado pelo uso, pela experiência", pode-se dizer que a língua é convencional se for considerada "como uma instituição social resultante do costume e da tradição, portanto, de um contrato tácito entre os homens." (DUBOIS,1993, p.153)

Portanto, o conceito da convencionalidade está aliado ao da arbritariedade, na medida em que a possibilidade de escolha da forma para um significado e a do significado para uma forma não depende da vontade pessoal do falante. Isto é, na teoria saussuriana, o conceito que exprime uma palavra como olhos não tem necessariamente uma relação com a sequência dos fonemas que forma essa palavra; a relação entre significado (conceito) e significante (imagem acústica) é meramente arbitrária: fruto de uma convenção social. Prova disso é que diferentes línguas usam diferentes palavras para designar olhos.

Tagnin, na obra intitulada $O$ jeito que a gente diz (2005, p. 15-16), afirma que a noção de convenção, no sentido de algo consolidado pelo uso ou pela prática, pode ser aplicada à língua nos níveis social e linguístico. O primeiro diz respeito a quando se deve dizer algo e o segundo a saber como dizer algo. Menciona o uso de expressões convencionais usadas em determinados eventos sociais, como Feliz Natal. Outro exemplo é a expressão convencional Meus Pêsames, usada para cumprimentar alguém pelo falecimento de uma pessoa querida. Essas são expressões convencionais ligadas a um evento social. Contudo, esclarece a autora, há outras expressões que são convencionais devido a sua forma, como, por exemplo, ledo engano. 
Convencionou-se que os vocábulos, ledo e engano devem aparecer nessa ordem. A subversão dessa ordem - engano ledo - provocaria a quebra da convencionalidade linguística, causando estranhamento ao receptor da mensagem.

\subsection{A idiomaticidade}

Quando a convenção, como anteriormente definida e exemplificada, passa para o nível semântico, entra-se, então, no campo da "idiomaticidade" (TAGNIN, 2005). O Longman Dictionary of English Idioms define expressão idiomática como sendo "um grupo de palavras fixas com um significado especial e diferente dos significados das palavras isoladas." ${ }^{116}$

Para ilustrar tal definição, cita-se, no dicionário, a expressão to spill the beans, que não possui relação semântica com a palavra beans ("feijão", em português). A expressão idiomática significa, de fato, to tell something that is secret, cuja tradução poderia ser, "contar um segredo". Portanto, o significado da expressão acima foi convencionado. Buscando na língua portuguesa uma expressão cujo significado seja equivalente ao exemplo acima citado, encontrase a expressão idiomática "dar com a língua nos dentes", cujo significado não é tão opaco quanto o da expressão equivalente em inglês, devido ao fato de seus componentes linguísticos remeterem o falante ao ato da fala. Acredita-se, desta forma, que o seu significado poderia ser facilmente identificado pelo contexto.

Ao definir expressão idiomática, Tagnin (2005, p. 16) ressalta que idiomático significa "não transparente" ou "opaco". Portanto, nas palavras da autora, "uma expressão é idiomática apenas quando seu significado não é

${ }^{116}$ is a fixed group of words with a special different meaning from the meanings fo the separate words" 
transparente", isto é, quando o significado total da expressão não pode ser deduzido a partir do significado das partes que a compõem. O grau de idiomaticidade dessas expressões pode variar. Há expressões que são mais, outras menos idiomáticas, dependendo de seu nível de transparência ou opacidade.

Tagnin (2005, p. 67) classifica como menos idiomáticas aquelas expressões em que nem todos os elementos linguísticos são idiomáticos ou as expressões metafóricas, cuja imagem seja facilmente decifrada; e como totalmente idiomáticas as expressões cujos elementos linguísticos não contribuem para o seu significado.

Seguem abaixo excertos do corpus de estudo desta pesquisa que exemplificam diferentes graus de idiomaticidade ${ }^{117}$ : baixo e total. No primeiro exemplo abaixo, a expressão "passam pela minha cabeça", traduzida por "pass through my mind" pode ser considerada mais transparente, pois nem todos os seus elementos são idiomáticos, portanto a sua imagem metafórica é de fácil entendimento, uma vez que, remete o leitor à ideia de conceber ou construir algo na imaginação.

Já no segundo exemplo, a expressão "com a roupa do corpo", cuja tradução foi "with the shirt on my back", é dotada de uma opacidade maior, podendo causar ao leitor certa dificuldade de compreensão, pois não possui nenhum elemento que o direcione ao significado total da expressão, ou seja, todos os seus elementos são idiomáticos.

\footnotetext{
117 Uma análise detalhada abarcando esses excertos será apresentada no Capítulo V; neste momento servem apenas como ilustração dos conceitos apresentados.
} 
1. ESTPO: Várias coisas passam

pela minha cabeça, mas não encontro uma boa resposta.

2. BUDPO: Dispensei a sopa, abandonei o lar com a roupa do corpo e me ajeitei na agência, onde ficava namorando meus artigos até adormecer no sofá.
ESTIT: Several things pass through my mind, but I can't find a good reply.

BUDIT: I forwent the soup, left home with the shirt on my back and settled into the agency, where I enjoyed the company of my articles until I fell asleep on the sofa

Recorrendo ainda ao critério da transparência, pode-se concluir que toda expressão idiomática é convencional, mas nem toda expressão convencional é ao mesmo tempo idiomática, e.g. "Feliz Dia dos Pais". A expressão classificada neste estudo como convencional, ao contrário da idiomática, é semanticamente transparente. Já a expressão idiomática, considerando os diferentes níveis de idiomaticidade, tem como característica a opacidade do sentido, pois o seu significado não decorre da somatória de seus componentes linguísticos, e.g. "Como quem vai tirar o pai da forca".

\subsection{A convencionalidade nos níveis sintático e semântico.}

$\mathrm{Na}$ classificação proposta por Tagnin (2005, p. 17-20), a convencionalidade pode acontecer em diversos níveis da língua, como fonológico, morfológico, pragmático sintático, e semântico. Considerando o escopo da análise desta pesquisa, tratar-se-á da convencionalidade nos níveis sintático e semântico. O nível sintático pode ser subdividido em três itens: 
combinabilidade, ordem e gramaticalidade. É de especial relevância para esta pesquisa $^{118}$ o item "combinabilidade", que consiste na possibilidade de combinação entre os elementos linguísticos. Como observa a autora: "Existem palavras que se associam de forma tão natural que a única explicação possível é de que essa associação tenha sido consagrada pelo uso", ou seja, tal combinação entre elementos linguísticos é convencional (e.g. "prestar atenção", no inglês pay attention).

No nível semântico, a convencionalidade é observada "na relação não motivada entre uma expressão e seu significado", como no seguinte exemplo extraído do romance Budapeste, acompanhado de sua respectiva tradução, onde as expressões "sair do meu pé" e "lay off my back" significam "deixar em paz". O significado dessas expressões foi convencionado, pois não corresponde ao significado das partes que as compõem tanto em português quanto em inglês:

BUDPO: O book deveria me servir de estímulo para retornar ao trabalho: o alemão não_sai do meu pé, cara, tem que tocar o novo livro, eu até descolei um patrocínio [...]

BUDIT: The portfolio was supposed to serve as encouragement for me to return to work: Look, mate, I can't get the German off my back, you've gotta get the new book happening, I've even swung a sponsor [...]

Outros exemplos de traduções de expressões idiomáticas serão analisados detalhadamente no Capítulo V deste trabalho.

\footnotetext{
${ }^{118}$ A importância deste item deve-se ao fato de que nesta pesquisa propõe-se analisar algumas traduções em que ocorreu a quebra intencional da "combinabilidade" dos elementos linguísticos pelo autor da obra original.
} 


\subsection{As colocações}

A "colocação" lexical pode ser definida "como a tendência de duas ou mais palavras co-ocorrerem ou como a tendência de uma palavra atrair outra" (HUSTON, 2002, p. 68) ${ }^{119}$. Segundo Tagnin (2005), geralmente, a combinabilidade dos elementos linguísticos que fazem parte da colocação escapa a uma explicação semântica.

Entretanto, Huston afirma que a combinação entre palavras pode ser ou não motivada. Como exemplo de colocação motivada, ela cita a palavra toys (brinquedo) que geralmente aparece em companhia da palavra children (crianças). A explicação é lógica, pois toys (brinquedos) estão mais relacionados a children (crianças), do que a adultos. Outras colocações, tais como strong tea (chá forte) e powerful car (carro possante) não parecem ser motivadas. Cabe ressaltar que em português o colocado "possante" é frequentemente usado para descrever a potência do "motor" (formando a colocação motor possante) e não do carro.

A colocação é formada por uma base e um ou mais colocados. Exemplificando, em "amigo íntimo", "amigo" é a base e "íntimo" é o colocado. Como esclarece Tagnin (2005), a base é a palavra que carrega maior carga semântica, a que determina a ocorrência da outra, pois elas não possuem o mesmo status. O colocado, por sua vez, é a sua companhia, a palavra que acompanha a base em um determinado contexto.

No escopo desta pesquisa, por exemplo, foram analisados, em contexto, o vocábulo "olhos" e seus colocados, ou seja, os elementos linguísticos que coocorrem com ele: "olhos fugiram do assunto", "ruído de olhos", "olhos

119 The tendency of two or more words to co-occur, or as the tendency of one word to attract another." 
gravitando". O mesmo procedimento foi adotado com relação às suas respectivas traduções: eyes avoiding the topic, sound of eyes, eyes bobbing etc.

\subsection{Colocados Criativos: manipulação linguística e criatividade.}

Como afirma Kenny (2001, p. 189), "a manipulação de padrões sintagmáticos recorrentes em uma língua é frequentemente a base do humor, da ironia ou da criatividade no texto." ${ }^{120}$ Esse tipo de manipulação, na opinião da autora, permite ao autor mostrar tanto o seu talento criativo com relação ao uso da linguagem quanto o seu conhecimento da cultura envolvida no processo de criação textual, enquanto que o leitor se sente bem por ser capaz de reconhecer a relação entre as formas linguísticas manipuladas e as consagradas.

Como já mencionado no capítulo introdutório, a decisão de se investigar os colocados criativos e suas respectivas traduções, no âmbito dos vocábulos selecionados para análise, partiu de uma informação dada por Chico Buarque na entrevista concedida a este pesquisador sobre uma discordância entre ele e Peter Bush, o tradutor de Estorvo, acerca da tradução da combinação "cheiro pesado". Esse episódio, narrado pelo autor, mostra de forma exemplar o que vem a ser um colocado criativo. De acordo com os padrões convencionais da língua portuguesa, quando um falante deseja descrever ou se referir a um tipo de "cheiro" desagradável, comumente usa-se o adjetivo "forte", formando, a colocação "cheiro forte". Contudo, o autor teve a intenção explícita de escapar da forma convencional e optou pelo uso do adjetivo "pesado", que não é

${ }^{120}$ The manipulation of recurring syntagmatic patterns in a language is often the basis of humour, irony, or creativity in text. 
convencional no português brasileiro quando ocorre em companhia do substantivo "cheiro", portanto, trata-se de uma combinação criativa, resultante da quebra da colocação "cheiro forte", que foi resgatada na tradução, graças à interferência do autor:

ESTPO: "No extremo do balcão, um

corredor que só atravessa andando

de lado leva a um mictório com um

cheiro muito pesado."
ESTIT: "At the end of the counter, a passage you can only walk along sideways leads to a lavatory with a heavy smell."

Outros exemplos de colocados criativos e de suas traduções, que constituem os objetos de estudo desta pesquisa, serão analisados no capítulo V. 
CAPÍTULO IV

Metodologia

Esta pesquisa fez uso da base metodológica da Linguística de Corpus e é de natureza quantitativa e qualitativa, isto é, a partir do levantamento quantitativo e estatístico feito por meio do uso de ferramentas computacionais, foi possível identificar itens textuais relevantes para o desenvolvimento de uma análise qualitativa das já citadas obras originais e traduzidas que integram o corpus de estudo.

Vale reiterar a importância metodológica da LC, pois o mero cotejo manual entre originais e traduções não teria sido suficiente para revelar fatos sobre as obras analisadas que não se havia pensado em procurar (e.g. a forte presença do campo semântico de palavras relacionadas às partes do corpo humano, como "olhos", "cabeça", "costas", dentre outras).

\subsection{Descrição do corpus}

Após várias tentativas infrutíferas junto às editoras, Companhia das Letras e Bloomsbury, para conseguir os mencionados romances de Chico Buarque e suas traduções para o inglês já em forma eletrônica, as obras originalmente impressas foram digitalizadas por meio da utilização de um scanner. Em uma primeira instância, o software OmniPage permite que se faça uma correção semi-automática do material escaneado. Após essa primeira correção, ainda é necessário que se faça uma nova correção do material, cotejando o material impresso com o digitalizado. Posteriormente, os textos 
foram gravados em formato texto ( ${ }^{*}$.txt) para que pudessem ser reconhecidos e processados pelo programa computacional WordSmith Tools, descrito no Capítulo II.

O corpus desta pesquisa é constituído de três obras literárias de Chico Buarque, a saber, Estorvo (1990), Benjamim (1995) e Budapeste (2003), e suas respectivas traduções para o inglês Turbulence (1992), Benjamim (1997) e Budapest (2004), constituindo, dessa forma, o corpus de estudo paralelo, formado pelo conjunto de textos originais e suas respectivas traduções com o propósito de ser investigado. Os referidos textos originais e traduzidos formam o que se denomina na LC, corpus de estudo, ou seja, os textos que se pretende.

As tabelas abaixo descrevem estatisticamente a constituição do corpus de estudo desta pesquisa: português original e inglês traduzido.

\begin{tabular}{lccc}
\hline Obras & ESTPO & BENPO & BUDPO \\
\hline Types (vocábulos) & 6.003 & 7.882 & 7.929 \\
Tokens & 33.959 & 37.212 & 40.900 \\
(ocorrências) & & & \\
\hline
\end{tabular}

TABELA 1 - Dados estatísticos do corpus de estudo em português original. ESTPO = Estorvo Português Original, BENPO = Benjamim Português Original e BUDPO = Budapeste Português Original.

\begin{tabular}{lccc}
\hline Obras & ESTIT & BENIT & BUDIT \\
\hline Types (vocábulos) & 5.015 & 6.202 & 6.132 \\
Tokens & 35.600 & 40.686 & 45.289 \\
(ocorrências) & & & \\
\hline
\end{tabular}

TABELA 2 - Dados estatísticos do corpus de estudo em inglês original. ESTIT = Estorvo Inglês Traduzido, BENIT = Benjamim Inglês Traduzido e BUDIT = Budapeste Inglês Traduzido .

As seis obras, sendo três originais e três suas respectivas traduções, formam um corpus de 233 mil palavras. 
Utilizaram-se também corpora de referência, em português e em inglês. O corpus de referência, cuja função primordial é oferecer um padrão de comparação com o corpus de estudo. A utilização desses corpora será detalhada ainda neste capítulo quando se mencionar sobre o uso da ferramenta KeyWords.

Os quadros abaixo relacionam os corpora de referência utilizados nesta pesquisa e suas características básicas:

QUADRO 1 - Corpora de referência de língua portuguesa

\begin{tabular}{|l|l|l|l|}
\hline \multicolumn{1}{|c|}{ Corpus } & Palavras & \multicolumn{1}{|c|}{ Composição } & \multicolumn{1}{c|}{ Localização } \\
\hline Banco de Português & 233 milhões & $\begin{array}{l}\text { Português } \\
\text { brasileiro, escrito e } \\
\text { falado }\end{array}$ & PUC/SP \\
\hline $\begin{array}{l}\text { CR-LW (Corpus de } \\
\text { Referência Lácio-Web) }\end{array}$ & 10 milhões & Português escrito & USP, NILC \\
\hline Corpus do Português & 45 milhões & $\begin{array}{l}\text { Português } \\
\text { brasileiro } \\
\text { e europeu }\end{array}$ & $\begin{array}{l}\text { Brigham Young } \\
\text { University }\end{array}$ \\
\hline Corpus Brasileiro & 1 bilhão & $\begin{array}{l}\text { Português } \\
\text { brasileiro } \\
\text { contemporâneo, } \\
\text { escrito e falado }\end{array}$ & PUC/SP \\
\hline
\end{tabular}

QUADRO 2 - Corpora de referência de língua inglesa

\begin{tabular}{|l|l|l|}
\hline \multicolumn{1}{|c|}{ Corpus } & \multicolumn{1}{|c|}{ Palavras } & \multicolumn{1}{c|}{ Composição } \\
\hline $\begin{array}{l}\text { Brown Corpus (Brown } \\
\text { University Standard } \\
\text { Corpus of Present-day } \\
\text { American English) }\end{array}$ & 1 milhão & Inglês americano, escrito \\
\hline $\begin{array}{l}\text { BNC (British National } \\
\text { Corpus) }\end{array}$ & 100 milhões & $\begin{array}{l}\text { Inglês britânico, escrito e } \\
\text { falado }\end{array}$ \\
\hline $\begin{array}{l}\text { COCA (Corpus of } \\
\text { Contemporary American } \\
\text { English) }\end{array}$ & 410 milhões & $\begin{array}{l}\text { Inglês americano e } \\
\text { britânico, escrito e falado }\end{array}$ \\
\hline
\end{tabular}




\subsection{Procedimentos de análise do corpus}

Segue abaixo a descrição do percurso realizado para se definir o que poderia ser analisado no corpus de estudo. Essa trajetória teve início a partir da geração de uma lista de palavras, passando pela extração das palavras-chave e chegando à seleção dessas palavras para análise em contexto.

\subsection{Levantamento das Word Lists (WL) - Listas de Frequência}

Como sugere Bowker (2002, p. 109), quando se embarca em uma pesquisa baseada em corpus, uma das melhores formas de se iniciar essa jornada é gerando uma lista de palavras do corpus de estudo. Portanto, o primeiro passo após a digitalização das obras investigadas foi produzir as listas de frequência de palavras do corpus de estudo, ou seja, uma WL formada pelo conjunto das três obras originais (wlcepo.list, anexo 2.7) e outra WL composta pelo conjunto de suas respectivas traduções para o inglês (wlceit.list, anexo 2.8), e, posteriormente, de cada uma das obras nas suas duas versões: original e tradução.

Para confecção dessas listas, utilizou-se a ferramenta WordList, que faz parte do programa WordSmith Tools, anteriormente descrita. O primeiro exame das listas de palavras do referido corpus de estudo (wlcepo.Ist, anexo 2.7) forneceu algumas ideias sobre o que poderia ser investigado. Como é de praxe ocorrer, notou-se, observando as 100 primeiras palavras da $\mathrm{WL}$, que as palavras de maior ocorrência no corpus eram palavras gramaticais (preposições; artigos; pronomes; conjunções etc.). Dentre as palavras de conteúdo (substantivos, verbos, adjetivos e advérbios), destacaram-se os 
índices de frequência percentual de palavras relacionadas às partes do corpo humano: mão $(0,18 \%)$; olhos $(0,15 \%)$; cabeça $(0,14 \%)$; rosto $(0,12 \%)$ e boca $(0,11 \%) .{ }^{121}$

A partir do exame da lista de frequência do corpus de estudo em português original, analisei as listas de palavras do corpus de estudo em inglês traduzido e de cada uma das obras para verificar se palavras que fazem parte do campo semântico referente ao corpo humano também se destacavam nas obras individualmente, tanto no português original quanto no inglês traduzido. Constatou-se a mesma tendência em todas elas.

As listas de frequência servem como um ponto de partida para análise do corpus. Contudo, não é pertinente se fazer afirmações generalizadas com base apenas na lista de palavras, pois elas aparecem fora de contexto. Para ilustrar esta afirmação, cito o fato de que na lista de frequência do romance Budapeste (wlbudpo.Ist, anexo 2.3) aparece o vocábulo "língua". Em um primeiro momento, poderia pensar em incluí-lo no rol de palavras que fazem parte do campo semântico relacionado às partes do corpo humano. Mas, ao buscar essa palavra nos contextos nos quais ela ocorreu no referido romance ${ }^{122}$ verificou-se que, na maioria das ocorrências ${ }^{123}$, ela não pertence a esse campo semântico, pois tem o seu significado atrelado aos idiomas falados pelos personagens do romance Budapeste, o húngaro e o português. Tanto é que foi traduzida por tongue ou, mais frequentemente, por language, que aparece na WL de Budapest (wlbudit.Ist, anexo 2..6) com o índice de

\footnotetext{
${ }^{121}$ Foi estabelecida a percentagem mínima de 0,05 do total de palavras do texto para efeito de relevância para análise.

${ }^{122}$ Essa busca foi feita utilizando-se a ferramenta Concordance, do programa WST, descrita anteriormente no Capítulo III.

${ }_{123}$ Das cinquenta e três ocorrências do vocábulo "língua" em Budapeste, oito referem-se ao órgão humano, nos demais casos o significado de "língua" está relacionado aos idiomas húngaro e português.
} 
frequência percentual de $0,12 \%$, praticamente o mesmo de "língua" original, que é de $0,13 \%$ com relação aos demais vocábulos no texto. Seguem, abaixo, dois excertos que exemplificam o que se acabou de afirmar:

1. BUDPO: Mas para quem adotou uma nova língua, como a uma mãe que se selecionasse, para quem procurou e amou todas as suas palavras, a persistência de um sotaque era um castigo injusto.

BUDIT: But for one who had adopted a foreign tongue as if hand-picking his own mother, for one who had sought out and loved every last one of its words, the persistence of an accent was an unfair punishment.

2. BUDPO: Depois de uma noite a falar a minha língua e a sonhar que Kriska falava português, me vi sem embocadura para o húngaro, feito músico soprando um instrumento em falso.

BUDIT: After a night of speaking my language and dreaming that Kriska spoke Portuguese, I found myself without the mouth for Hungarian, like a musician blowing an instrument in vain.

Contudo, nas obras Estorvo e Benjamim não se repetiu a mesma tendência que ocorrera em Budapeste, ou seja, nesses dois romances, o vocábulo "língua" tem o seu sentido mais frequentemente relacionado ao órgão humano e não a um idioma ${ }^{124}$. Pode-se concluir que, em Budapeste, o vocábulo "língua", na maioria de suas ocorrências, tem o seu significado atrelado ao de um "idioma" devido à temática do romance, que possui como um de seus ingredientes a questão do estrangeiro: o protagonista é um sujeito que se desloca entre duas culturas e dois idiomas.

As tabelas abaixo mostram as palavras pertencentes ao campo semântico do corpo humano nos corpora de estudo em português original e inglês traduzido, por ordem de frequência no corpus com percentagem mínima de $0,05 \%$ do total de palavras do texto.

\footnotetext{
${ }^{124}$ Das seis ocorrências do vocábulo língua em Estorvo, duas se referem a um idioma e em Benjamim das seis ocorrências do mesmo vocábulo, apenas uma se refere à língua no sentido de idioma.
} 


\begin{tabular}{|c|c|c|}
\hline Word & Freq. & $\%$ \\
\hline MÁO & 197 & 0,18 \\
\hline OLHOS & 173 & 0,15 \\
\hline CABEÇA & 152 & 0,14 \\
\hline ROSTO & 132 & 0,12 \\
\hline BOCA & 123 & 0,11 \\
\hline
\end{tabular}

TABELA 3 - Palavras pertencentes ao campo semântico do corpo humano no corpus de estudo em português original.

\begin{tabular}{|c|c|c|}
\hline Word & Freq. & $\%$ \\
\hline FACE & 189 & 0,16 \\
\hline HAND & 180 & 0,15 \\
\hline EYES & 171 & 0,14 \\
\hline HEAD & 160 & 0,13 \\
\hline MOUTH & 97 & 0,08 \\
\hline
\end{tabular}

TABELA 4 - Palavras pertencentes ao campo semântico do corpo humano no corpus de estudo em inglês traduzido.

\subsection{KeyWords: $\mathrm{O}$ que elas podem revelar?}

Como foi possível observar, as listas de frequência, em uma primeira instância, forneceram informações sobre as palavras que, pelo seu alto índice de frequência, seriam candidatas a uma investigação mais aprofundada. Contudo, elas "não contam toda a história" ${ }^{125}$

Com o objetivo de verificar se o uso frequente de palavras pertencentes ao campo semântico do corpo humano é, de fato, uma característica da obra de Chico Buarque, comparou-se o Corpus de Estudo do português original (wlcepo.Ist, anexo 1.7) com o Corpus de Referência Lácio-Web (wlcrpo2, anexo 1.10). O resultado dessa operação, utilizando-se a ferramenta KeyWords do programa WST anteriormente descrita, foi a lista de palavras-chave que identificou palavras que ocorrem com uma frequência incomum no Corpus de

125 "Word lists do not tell the whole story" (BOWKER, 2002, p.113) 
Estudo quando comparada com a lista de palavras do citado Corpus de Referência.

A tabela abaixo mostra treze palavras pertencentes ao campo semântico do corpo humano, que figuram entre as primeiras noventa palavras-chave que compõem a kwl acima mencionada. Considerando que índices de chavicidade acima de 4,0 são considerados relevantes para análise, como já mencionado no Capítulo III, cabe chamar a atenção para o alto índice de chavicidade destas palavras-chave.

\begin{tabular}{|l|c|c|c|c|c|c|}
\hline \multicolumn{1}{|c|}{ WORD } & FREQ. & CEPO.LST \% & FREQ. & PO2.LST \% & KEYNESS & \multicolumn{1}{c|}{ P } \\
\hline OLHOS & 173 & 0,15 & 499 & & 701,1 & $\begin{array}{l}0,00000 \\
0\end{array}$ \\
\hline MÃO & 197 & 0,18 & 819 & 0,01 & 679,5 & $\begin{array}{l}0,00000 \\
0\end{array}$ \\
\hline BOCA & 123 & 0,11 & 189 & & 620 & $\begin{array}{l}0,00000 \\
0\end{array}$ \\
\hline ROSTO & 132 & 0,12 & 255 & & 619,3 & $\begin{array}{l}0,00000 \\
0\end{array}$ \\
\hline CABEÇA & 152 & 0,14 & 844 & 0,01 & 450,8 & $\begin{array}{l}0,00000 \\
0\end{array}$ \\
\hline CABELOS & 77 & 0,07 & 84 & & 426,1 & $\begin{array}{l}0,00000 \\
0\end{array}$ \\
\hline COSTAS & 71 & 0,06 & 121 & & 346,7 & $\begin{array}{l}0,00000 \\
0\end{array}$ \\
\hline CARA & 91 & 0,08 & 371 & & 316,8 & $\begin{array}{l}0,00000 \\
0\end{array}$ \\
\hline PÉ & 80 & 0,07 & 322 & & 280,2 & $\begin{array}{l}0,00000 \\
0\end{array}$ \\
\hline DEDOS & 52 & 0,05 & 64 & & 278,9 & $\begin{array}{l}0,00000 \\
0\end{array}$ \\
\hline PERNAS & 54 & 0,05 & 89 & & 266,5 & $\begin{array}{l}0,00000 \\
0\end{array}$ \\
\hline LÁBIOS & 38 & 0,03 & 15 & & 256,3 & $\begin{array}{l}0,00000 \\
0\end{array}$ \\
\hline MÃOS & 86 & 0,08 & 485 & & 252,8 & $\begin{array}{l}0,00000 \\
0\end{array}$ \\
\hline
\end{tabular}

Tabela 5 - Primeiras treze palavras-chave pertencentes ao campo semântico do corpo humano no corpus de estudo em português original comparado com o corpus de referência Lácio-Web Geral.

Com o objetivo de verificar se o mesmo campo semântico encontra-se presente também nas traduções, comparou-se o corpus de estudo em inglês traduzido com o corpus de referência Brown. A lista de palavras-chave do 
corpus de estudo do inglês traduzido mostra que ele ocorre também nas traduções, porém o número de palavras pertencentes ao campo semântico do corpo humano, que figuram entre as primeiras noventa palavras da referida $k w l$, é menor, se comparado ao número de palavras-chave pertencentes ao mesmo campo semântico, que aparecem entre as primeiras noventa palavras da $k w l$ do corpus de estudo em português original, como mostra a tabela 6 abaixo:

\begin{tabular}{|c|c|c|c|c|c|c|}
\hline WORD & FREQ. & CEIT.LST \% & FREQ. & RIN1.LST \% & KEYNESS & $\mathrm{P}$ \\
\hline FACE & 189 & 0,16 & 1.468 & 0,03 & 318,5 & 0,000000 \\
\hline HAIR & 117 & 0,10 & 586 & 0,01 & 277,3 & 0,000000 \\
\hline MOUTH & 97 & 0,08 & 412 & & 255,4 & 0,000000 \\
\hline BACK & 284 & 0,23 & 3,946 & 0,07 & 253,7 & 0,000000 \\
\hline HAND & 180 & 0,15 & 1.712 & 0,03 & 248,9 & 0,000000 \\
\hline EYES & 171 & 0,14 & 1.588 & 0,03 & 242,4 & 0,000000 \\
\hline HEAD & 160 & 0,13 & 1.686 & 0,03 & 197,6 & 0,000000 \\
\hline
\end{tabular}

Tabela 6 - Primeiras seis palavras-chave pertencentes ao campo semântico do corpo humano no corpus de estudo em inglês traduzido comparado com o corpus de referência Brown.

Partindo-se do princípio de que a utilização de outros corpora de referência de proporções maiores poderia, em princípio, retornar mais palavraschave do que aqueles de tamanhos menores (BERBER SARDINHA, 2004, p.102), novas listas de palavras-chave foram geradas. Desta vez, comparando o corpus de estudos em português com o corpus de referência Banco de Português. A segunda lista de palavras-chave do corpus de estudo em português original (kwcepo3.kws, anexo 3.7), gerada a partir dessa comparação, apresentou, entre as noventa primeiras palavras da referida $K W L$, 14 palavras-chave pertencentes ao campo semântico do corpo humano (Tabela 7 abaixo), enquanto que a primeira $K W L$, gerada a partir da comparação com o corpus de referência Lácio-Web (Tabela 5), apresentou 13 
palavras-chave, entre as noventa primeiras palavras da referida $K W L$; uma diferença mínima, - de apenas uma palavra-chave pertencente ao referido campo semântico, entre as noventa primeiras palavras da lista de palavraschave -, se consideradas as proporções dos dois corpora de referência: o Banco de Português com 233 milhões de palavras e o Lácio-Web com 10 milhões de palavras.

\begin{tabular}{|l|c|c|c|c|c|c|}
\hline WORD & FREQ. & EPO.LST \% & FREQ. & PO3.LST \% & KEYNESS & $P$ \\
\hline OLHOS & 173 & 0,15 & 17.275 & & 716,1 & 0,000000 \\
\hline ROSTO & 132 & 0,12 & 8.637 & & 652,9 & 0,000000 \\
\hline MÃO & 197 & 0,18 & 36.402 & 0,02 & 590,2 & 0,000000 \\
\hline BOCA & 123 & 0,11 & 16.108 & & 446,4 & 0,000000 \\
\hline CABEÇA & 152 & 0,14 & 32.076 & 0,01 & 418,9 & 0,000000 \\
\hline CABELOS & 77 & 0,07 & 5.004 & & 381,8 & 0,000000 \\
\hline DEDOS & 52 & 0,05 & 3.020 & & 269,1 & 0,000000 \\
\hline COSTAS & 71 & 0,06 & 8.535 & & 269 & 0,000000 \\
\hline LȦBIOS & 38 & 0,03 & 1.514 & & 224,3 & 0,000000 \\
\hline PERNAS & 54 & 0,05 & 5.686 & & 218,1 & 0,000000 \\
\hline CARA & 91 & 0,08 & 23.753 & 0,01 & 216,6 & 0,000000 \\
\hline MÃOS & 86 & 0,08 & 21.859 & & 208,6 & 0,000000 \\
\hline PÉ & 80 & 0,07 & 18.555 & & 207 & 0,000000 \\
\hline BRAÇOS & 47 & 0,04 & 5.155 & & 186,2 & 0,000000 \\
\hline
\end{tabular}

Tabela 7 - Primeiras 14 palavras-chave pertencentes ao campo semântico do corpo humano no corpus de estudo em português original (kwcepo3.kws, anexo 3.7) comparado com o corpus de referência Banco de Português.

Comparou-se também o corpus de estudo em inglês traduzido com o corpus de referência BNC (British National Corpus), um corpus de 100 milhões de palavras. Ao se examinar a nova lista de palavras-chave do corpus de estudo em inglês traduzido (kwceit2kws, anexo 3.8), gerada a partir dessa comparação, constatou-se que o número de palavras-chave relacionadas às partes do corpo humano, contidas entre as primeiras noventa palavras-chave, não havia aumentado (Tabela 8 abaixo), mantendo-se idêntico ao da $K W L$ do 
corpus de estudo inglês traduzido comparado com o corpus de referência Brown (Tabela 6), que é um corpus de menor dimensão, com 1 milhão de palavras. Foram registradas 7 ocorrências de palavras-chave relacionadas ao campo semântico do corpo humano, entre as noventa primeiras palavra-chave, em ambas as listas.

\begin{tabular}{|l|c|c|c|c|c|c|}
\hline WORD & FREQ. & CEIT.LST $\%$ & FREQ. & RIN2.LST $\%$ & KEYNESS & P \\
\hline FACE & 189 & 0,16 & 35.983 & 0,04 & 264 & 0,000000 \\
\hline EYES & 171 & 0,14 & 29.727 & 0,03 & 263 & 0,000000 \\
\hline HAIR & 117 & 0,1 & 14.655 & 0,01 & 242,6 & 0,000000 \\
\hline MOUTH & 97 & 0,08 & 9.557 & & 241,2 & 0,000000 \\
\hline HAND & 180 & 0,15 & 39.176 & 0,04 & 215,2 & 0,000000 \\
\hline HEAD & 160 & 0,13 & 38.900 & 0,04 & 165,7 & 0,000000 \\
\hline BACK & 284 & 0,23 & 105.105 & 0,10 & 143,0 & 0,000000 \\
\hline
\end{tabular}

Tabela 8 - Primeiras sete palavras-chave pertencentes ao campo semântico do corpo humano no corpus de estudo em inglês traduzido (kwceit2. kWs, anexo 3.8) comparado com o corpus de referência BNC.

Como se pode perceber, o fato de o corpus de referência BNC ser expressivamente maior que o corpus de referência Brown, não fez com que retornasse um maior número de palavras-chave relacionadas ao campo semântico do corpo humano entre as noventa primeiras da $K W L$ do referido corpus de estudo. Esta constatação corrobora as palavras de Berber Sardinha, ao afirmar que não há necessidade de o pesquisador usar um corpus de referência cuja dimensão seja superior a cinco vezes o tamanho do corpus de estudo, "pois a quantidade de palavras-chave obtidas seria igualável a quantidades obtidas com corpora maiores" (2004, p. 102-103). Neste caso específico, o corpus de estudo do inglês traduzido possui 121,575 palavras, portanto é de uma dimensão muito inferior aos dos dois corpora de referência utilizados. 


\subsection{Os romances buarqueanos comparados entre si}

Após a constatação da presença do campo semântico relacionado às partes do corpo humano feita pela comparação do corpus de estudo como os citados corpora de referência, decidiu-se conduzir uma nova investigação com o intuito de ratificar a afirmação de que tal campo semântico representa, de fato, uma característica da obra de Chico Buarque. Bowker e Pearson (2002) afirmam que os tipos de corpora podem variar de acordo com a pesquisa que se pretende realizar, isto é, por mais representativo que seja um corpus de referência, ele possui suas limitações e pode não atender a todos os propósitos da investigação.

Assim, foram reunidos os corpora abaixo descritos, cuja função foi servir de contraste para cada uma das obras que compõem o corpus de estudo, ou seja, cada obra foi contrastada com as outras duas da mesma língua.

QUADRO 3 - Corpora de contraste para as obras em português

\begin{tabular}{|l|l|l|}
\hline \multicolumn{1}{|c|}{ Corpus } & \multicolumn{1}{|c|}{ Palavras } & \multicolumn{1}{c|}{ Composição } \\
\hline Benjamin e Budapeste & 78.112 & $\begin{array}{l}\text { Português brasileiro original } \\
\text { escrito }\end{array}$ \\
\hline Estorvo e Budapeste & 74.859 & $\begin{array}{l}\text { Português brasileiro original } \\
\text { escrito }\end{array}$ \\
\hline Estorvo e Benjamin & 71.171 & $\begin{array}{l}\text { Português brasileiro original } \\
\text { escrito }\end{array}$ \\
\hline
\end{tabular}

QUADRO 4 - Corpora de contraste para as obras em inglês

\begin{tabular}{|l|l|l|}
\hline \multicolumn{1}{|c|}{ Corpus } & Palavras & \multicolumn{1}{c|}{ Composição } \\
\hline Benjamin e Budapeste & 85.975 & Inglês traduzido escrito \\
\hline Estorvo e Budapeste & 80.889 & Inglês traduzido escrito \\
\hline Estorvo e Benjamin & 76.286 & Inglês traduzido escrito \\
\hline
\end{tabular}


Após o contraste de cada uma das obras com as outras duas, nas duas línguas, o resultado foi o apagamento total do campo semântico referente às partes do corpo humano, entre as noventa primeiras palavras das listas de palavras-chave dos corpora de estudo, tanto em português original quanto em inglês traduzido. Esse fenômeno ocorreu devido ao fato de essas palavraschave terem um alto índice de chavicidade tanto no corpus de estudo quanto no corpus de contraste. Portanto, elas se anularam, o que comprova que tais palavras são característica das obras de Chico Buarque, que constituem o corpus de estudo desta pesquisa.

Concluída esta etapa, foi possível comprovar que as KeyWords destacaram aquilo que é peculiar, característico na obra de Chico Buarque, oferecendo, dessa forma, uma indicação mais concreta de que as traduções das palavras que fazem parte do campo semântico relacionado ao corpo humano são dignas de análise, pois representam um aspecto importante na obra original do autor.

\subsection{Seleção e investigação das palavras-chave: etapas e procedimentos}

O próximo passo, após a comprovação da presença do campo semântico relacionado às partes do corpo no corpus de estudo, foi definir quais dessas palavras-chave, pertencentes ao referido campo semântico, seriam investigadas. Partiu-se, então, para um levantamento exaustivo dessas palavras-chave em cada uma das obras originais ${ }^{126}$.

\footnotetext{
${ }^{126}$ Para a realização deste levantamento, fez-se a alteração no setting do programa WST, relacionado à geração de KeyWords. O número máximo de palavras-chave (KeyWords) passou de 500 para 1000 e a frequência mínima de 10 foi modificada para 1.
} 
Feito esse levantamento individual, selecionaram-se aquelas com índice de chavicidade igual ou superior a cinquenta $(=$ ou $>50)$. Posteriormente, extraíram-se dessa lista aquelas que figuravam entre as noventa primeiras da $K W L$. E, finalmente, foram selecionadas - para posterior análise, em contexto, e acompanhadas de suas respectivas traduções - aquelas que se repetiam nas três obras. As palavras-chave selecionadas foram, portanto: "olhos"; "mão"; "cabeça"; "boca"; "cabelos" e "costas". As tabelas a seguir ilustram o percurso realizado para se chegar a essas seis palavras-chave. 
Feita a seleção, seguindo os critérios acima descritos, passou-se, com o auxílio das ferramentas computacionais Concordance, do programa WST, e Parallel Search, do programa ParaConc, já descritas no Capítulo III, a investigar tais palavras-chave para não só confirmar os sentidos que elas possuem nos contextos onde ocorrem, como também para conhecer as palavras com as quais elas se associam.

As tabelas a seguir mostram, em termos absolutos e percentuais quantas das ocorrências pertencem, de fato, ao campo semântico do corpo humano, uma vez que, como já dito, "língua", por exemplo, nem sempre se refere ao órgão que serve para degustação.

\begin{tabular}{|c|c|c|c|c|c|c|c|}
\cline { 3 - 8 } \multicolumn{2}{c|}{} & \multicolumn{5}{c|}{ ESTORVO } & \\
\hline \multicolumn{2}{c|}{ VOCÁBULO } & \multicolumn{2}{|c|}{ PO } & \multicolumn{2}{c|}{ IT } & \\
\hline PO & IT & F.T & $€$ C.S & ESTPO & F.T & $€$ C.S & ESTIT \\
\hline BOCA & MOUTH & 34 & 34 & $100 \%$ & 28 & 26 & $93 \%$ \\
CABEÇA & HEAD & 62 & 62 & $100 \%$ & 57 & 50 & $88 \%$ \\
CABELOS & HAIR & 31 & 31 & $100 \%$ & 47 & 47 & $100 \%$ \\
COSTAS & BACK & 20 & 18 & $90 \%$ & 103 & 94 & $91 \%$ \\
MÃO & HAND & 66 & 66 & $100 \%$ & 58 & 53 & $91 \%$ \\
OLHOS & EYES & 30 & 30 & $100 \%$ & 32 & 31 & $97 \%$ \\
\hline
\end{tabular}

Tabela 22 - Dados estatísticos referente aos números absolutos e percentuais das palavraschave, no português original e no inglês traduzido, que pertencem ao campo semântico do corpo humano ( $€$ C.S) na obra Estorvo, no português original $(\mathrm{PO})$ e no inglês traduzido (IT).

\begin{tabular}{c|c|c|c|c|c|c|c|}
\cline { 3 - 8 } \multicolumn{2}{c|}{} & \multicolumn{5}{c|}{ BENJAMIM } & \\
\hline \multicolumn{2}{c|}{ VOCÁBULO } & \multicolumn{2}{|c|}{ PO } & \multicolumn{3}{c|}{ IT } & \\
\hline PO & IT & F.T & $€$ C.S & \multicolumn{1}{c|}{ BENPO } & F.T & $€$ C.S & BENIT \\
\hline BOCA & MOUTH & 47 & 46 & $98 \%$ & 41 & 40 & $98 \%$ \\
CABEÇA & HEAD & 35 & 35 & $100 \%$ & 41 & 39 & $95 \%$ \\
CABELOS & HAIR & 22 & 22 & $100 \%$ & 36 & 36 & $100 \%$ \\
COSTAS & BACK & 20 & 18 & $90 \%$ & 86 & 70 & $81 \%$ \\
MÃO & HAND & 53 & 52 & $98 \%$ & 57 & 53 & $93 \%$ \\
OLHOS & EYES & 63 & 62 & $98 \%$ & 66 & 66 & $100 \%$ \\
\hline
\end{tabular}

Tabela 23 - Dados estatísticos referente aos números absolutos e percentuais das palavraschave, no português original e no inglês traduzido, que pertencem ao campo semântico do corpo humano (€ C.S) na obra Benjamim, no português original (PO) e no inglês traduzido (IT). 


\begin{tabular}{c|c|c|c|c|c|c|c|}
\cline { 3 - 7 } \multicolumn{2}{c|}{} & \multicolumn{5}{c|}{ BUDAPESTE } & \\
\hline \multicolumn{2}{c|}{ VOCÁBULO } & \multicolumn{2}{c|}{ PO } & \multicolumn{2}{c|}{ IT } & \\
\hline PO & IT & F.T & $€$ C.S & BUDPO & F.T & $€$ C.S & BUDIT \\
\hline BOCA & MOUTH & 39 & 38 & $97 \%$ & 28 & 28 & $100 \%$ \\
CABEÇA & HEAD & 55 & 54 & $98 \%$ & 62 & 61 & $98 \%$ \\
CABELOS & HAIR & 24 & 24 & $100 \%$ & 34 & 34 & $100 \%$ \\
COSTAS & BACK & 27 & 27 & $100 \%$ & 95 & 16 & $17 \%$ \\
MÃO & HAND & 69 & 67 & $97 \%$ & 65 & 64 & $98 \%$ \\
OLHOS & EYES & 75 & 75 & $100 \%$ & 73 & 73 & $100 \%$ \\
\hline
\end{tabular}

Tabela 24 - Dados estatísticos referente aos números absolutos e percentuais das palavraschave, no português original e no inglês traduzido, que pertencem ao campo semântico do corpo humano (€ C.S) na obra Budapeste, no português original $(\mathrm{PO})$ e no inglês traduzido (IT).

Após esse levantamento, foi realizado o cotejo das linhas de concordância das obras originais com suas respectivas traduções e foram criados os quadros contendo as ocorrências das palavras-chave selecionadas para análise e suas respectivas traduções, bem como um espaço para a análise. Dessa forma, foi possível fazer um exame detalhado das traduções e eleger os aspectos mais relevantes para análise, sem perder de vista a ideia a partir da qual esta pesquisa de desenvolveu, ou seja, a busca nas obras originais e em suas traduções pela identificação de uma das características mais marcantes do autor, Chico Buarque: a sua habilidade de jogar com as palavras e de criar sentidos. Segue a reprodução de um dos quadros acima mencionados. 


\subsection{O que foi evidenciado a partir da comparação das frequências das palavras-chaves nas obras originais e nas traduções?}

Ao se fazer a comparação entre o número de ocorrências dos seis vocábulos pertencentes ao campo semântico de partes do corpo humano que foram selecionados para análise nas obras originais ("olhos", "mão", "boca", "cabeça", "cabelos" e "costas") e suas respectivas traduções literais (eyes, hand, mouth, head, hair e back) observou-se a existência de discrepâncias entre esses números no sentido inverso, ou seja, do inglês traduzido com relação ao português original.

Dentre esses seis vocábulos de língua inglesa, back foi o que apresentou a maior disparidade com relação ao número de ocorrências do vocábulo "costas" nas três obras traduzidas, seguido de "hair", que também aparece com maior frequência que "cabelos" nas três obras. O vocábulo "head" aparece com frequência superior à "cabeça" nas traduções de Benjamim e Budapeste. As frequências dos vocábulos hand e eyes com relação aos vocábulos "mãos" e "olhos", respectivamente, são superiores somente na tradução de Benjamim. Já o vocábulo mouth não apresentou tal discrepância no sentido inverso, ou seja, não possui um número de ocorrências superior a "boca" em nenhuma das obras traduzidas, como ilustra a tabela a seguir:

\begin{tabular}{|c|c|c|c|c|c|c|c|}
\cline { 3 - 8 } \multicolumn{2}{c|}{} & \multicolumn{2}{c|}{ ESTORVO } & \multicolumn{2}{c|}{ BENJAMIM } & \multicolumn{2}{c|}{ BUDAPESTE } \\
\hline \multicolumn{2}{c|}{ VOCÁBULO } & \multicolumn{2}{c|}{ Freq. } & \multicolumn{2}{c|}{ Freq. } & \multicolumn{2}{c|}{ Freq. } \\
\hline PO & IT & PO & IT & PO & IT & PO & IT \\
\hline BOCA & MOUTH & 34 & 28 & 47 & 41 & 39 & 28 \\
CABEÇA & HEAD & 62 & 57 & 35 & 41 & 55 & 62 \\
CABELOS & HAIR & 31 & 47 & 22 & 36 & 24 & 34 \\
COSTAS & BACK & 20 & 103 & 20 & 86 & 27 & 95 \\
MÃO & HAND & 66 & 58 & 53 & 57 & 69 & 65 \\
OLHOS & EYES & 30 & 32 & 63 & 66 & 75 & 73 \\
\hline
\end{tabular}

Tabela 25 - Frequência (Freq.) total das palavras-chave, no português original e no inglês traduzido, nas obras Estorvo, Benjamim e Budapeste, no português original (PO) e no inglês traduzido (IT). 
Para justificar tais discrepâncias, é possível pressupor, por exemplo, que o número de ocorrências do vocábulo back é superior ao número de ocorrências de "costas" devido ao fato de a palavra back possuir várias acepções na língua inglesa. Dentre as suas várias possibilidades de emprego, ela pode ser usada como substantivo ("costas, dorso, lado oposto, avesso" etc.) ou como advérbio (atrás, por trás, de novo, de volta etcA mesma hipótese pode ser levantada com relação ao vocábulo head, que possui vários significados na língua inglesa, além de "cabeça": além de significar "cabeça, cérebro, intelecto" na função de substantivo, pode ser usada como verbo, significando "avançar, dirigir-se para algum lugar"), só para mencionar algumas das inúmeras variações de significado da palavra head,

Contudo, com o objetivo de comprovar empiricamente as razões de tais disparidades e investigar as estratégias de tradução adotadas pelos tradutores, retornou-se às listas de concordância de cada um dos seis vocábulos traduzidos, na língua inglesa, e extraíram-se delas os casos em que tais vocábulos pertenciam ao campo do corpo humano, mas não foram traduzidos literalmente. Como exemplo, cita-se o caso no qual o vocábulo back pertence ao campo semântico de partes do corpo humano, mas não corresponde à tradução de "costas", e sim a tradução da palavra "corpo", na obra Benjamim:

BENIT: Ariela turns her back. $\quad$ BENPO: Ariela gira o corpo.

Foi possível tal procedimento de verificação utilizando-se os recursos oferecidos pelo software WST, cuja ferramenta Concordance possibilitou a verificação do significado da palavra de busca ${ }^{127}$ em contexto, tanto no português original como no inglês traduzido. Posteriormente fez-se o cotejo

\footnotetext{
${ }^{127}$ No caso específico desta pesquisa, as palavras de busca são aquelas que pertencem ao campo semântico do corpo humano.
} 
entre as linhas de concordância (inglês traduzido e português original) para verificar quando o vocábulo em inglês, embora pertencente ao campo semântico de partes do corpo humano, não havia sido traduzido "literalmente" pelo seu correspondente em inglês, como exemplificado no parágrafo anterior. Utilizou-se também o software ParaConc, cuja ferramenta parallel search possibilitou a localização da palavra de busca em contexto e sua respectiva tradução, descobrindo, desta forma, qual foi a solução encontrada pelo tradutor para cada um desses casos. A partir desse cotejo entre originais e traduções, criou-se o quadro a seguir, que serviu como um instrumento facilitador da investigação dos fenômenos tradutórios que causaram a referida discrepância entre os números de ocorrências das palavras-chave originais e suas respectivas traduções. 


\subsection{Descobertas a partir do cotejo dos originais com as traduções no sentido PO (português original) $\rightarrow$ IT (inglês traduzido)}

As palavras-chave constituem apenas o ponto de partida para análise das traduções. Assim como as palavras de maior inguístic no texto, as palavras-chave não dizem tudo sobre o texto, pois são apresentadas isoladamente. Por isso, elas foram examinadas de forma contextualizada, levando-se em conta as palavras que co-ocorrem com elas, ou seja, os seus colocados, cujo conceito foi descrito anteriormente no Capítulo III.

O cotejo trouxe à tona o uso criativo do autor ao romper com os padrões inguísticos normais de combinações entre esses elementos inguísticos, ou seja, ao "quebrar" uma colocação.

Foram identificados alguns colocados criativos como no seguinte trecho, em que o autor, no romance Budapeste, usa o substantivo "olhos" como sujeito da colocação "fugir do assunto":

BUDPO: Kriska, porém olhou para baixo, para os lados, para a janela, os anúncios, o túnel, seus olhos fugiram do assunto.
BUDIT: Kriska, however, looked down, to the sides, at the window, the advertisements, the tunnel, her eyes avoiding the topic.

Esse e outros excertos foram selecionados para análise, que será desenvolvida no próximo capítulo. Pretende-se, portanto, verificar se os tradutores quando realizaram suas traduções dessas palavras-chave e de seus colocados recuperaram a criatividade do autor. Tratando-se de uma pesquisa baseada em corpora, as afirmações sobre os níveis de convencionalidade e de 
criatividade dos colocados que acompanham as palavras-chave analisadas foram feitas com base no número de ocorrências dessas palavras nos corpora de referência utilizados para esta pesquisa: Corpus Brasileiro e Corpus of Comtemporary American English - COCA.

O número de ocorrências de determinada palavra ou expressão pode revelar quão convencional ou criativa ela é. Os registros de linguagem encontrados nesses corpora são dinâmicos e contínuos e servem como referência confiável do uso de vários tipos linguagem. O Corpus do Português (Cdp), embora seja fechado e diacrônico (Séc. XIV - XX), também foi consultado, devido à sua representatividade e por permitir, assim como os anteriores, realizar pesquisas das palavras-chaves analisadas e de suas palavras vizinhas em um sub-corpus do gênero literário. 


\section{CAPÍTULO V}

\section{Análise}

\subsection{Aspectos sobre as estratégias utilizadas pelos tradutores que foram revelados em decorrência dessa investigação no sentido inverso, ou seja, inglês - português.}

O primeiro ponto verificado como resultado da pesquisa feita no sentido inverso, ou seja, do português original para o inglês traduzido, foi que, em vários momentos, os vocábulos "eyes", "hand", "mouth", "head", "hair" e "back", nas traduções feitas por Bush, Clifford e Entrekin em referência às partes do corpo humano, não foram traduzidos de forma literal, como "olhos", "mão", "boca", "cabeça", "cabelos" e "costas". Por exemplo, "hair" foi usado na tradução de "cabeça" e o vocábulo "head" foi escolhido pelos tradutores para substituir "rosto", "pescoço", "queixo" e "cara". Portanto, esta é uma das razões pela qual o número de ocorrências desses vocábulos no inglês traduzido tornou-se superior ao número de ocorrências de tais vocábulos no português original. Em seguida, encontram-se as descrições dos casos que exemplificam esta constatação: 
Palavra de busca: Eyes

\section{Eyes $<$ Cornos}

1.a ESTIT: One more telephone call and the redhead will hand over to one of the twins who gets straight to the point; he'll say if they don't come up with the goods, the duchess's brother'll get lead between the eyes. 1.b ESTPO: Mais um telefonema, e o ruivo vai passar a palavra a um dos gêmeos, que irá direto ao ponto; dirá que se não pintar a grana, o irmão da dondoca leva chumbo no meio dos cornos.

Seguindo a metodologia anteriormente mencionada, constatou-se que, no seguimento acima, o vocábulo "eyes" corresponde à tradução de "cornos", que, em um registro bastante informal, refere-se à parte superior da face humana. A tradução literal de "cornos" por "horns" não faria sentido em inglês, uma vez que esse substantivo não possui esse mesmo sentido do português. Em nossa língua, o termo 'cornos' também pode ser usado com ironia, pois carrega a ideia de infidelidade, já a palavra 'horn' não possui essa outra acepção. Neste caso, o tradutor fez uma escolha lexical padrão dentro de sua própria língua, já que a tradução literal do termo 'cornos' para o inglês, por não soar fluente ou natural, causaria estranhamento ao leitor da língua de chegada, além de comprometer o sentido do texto. A mesma estratégia de tradução pode ser observada nos excertos abaixo, onde a convencionalidade na língua de chegada foi priorizada em detrimento da tradução literal: 
Palavra de busca: Hair

\section{Hair < Cabeça}

2.a ESTIT: Nor will they refuse me a telephone token at the bus station. I'll ring my mother, for I must lie down somewhere, have a bath, wash my hair.

3.a ESTIT: No way do I want to go to her house. All the same I want to drop in somewhere, I need to have a bath, I must wash my hair.

\section{4.a BENIT: Wetting his hair,} Benjamin wonders whether he will reveal to Ariela how petty he feels, for he is incapable of dreaming about anyone. 2.b ESTPO: Não haverão de me negar uma ficha telefônica na rodoviária. Ligarei para minha mãe, pois preciso me deitar num canto, tomar um banho, lavar a cabeça.

3.b ESTPO: Não quero ir para a casa dela de jeito nenhum. Mas ao mesmo tempo quero encostar num canto, tenho de tomar um banho, preciso lavar a cabeça.

4.b BENPO: Molhando a cabeça, Benjamim pergunta-se se revelará a Ariela o quanto se sente mesquinho, pois é incapaz de sonhar com quem quer que seja.

Nos três exemplos acima, o vocábulo "cabeça" foi traduzido por "hair", cuja tradução literal seria "cabelo". Se examinada isoladamente, seria de se estranhar tal tradução, mas, levando-se em conta seus colocados, ou seja, os verbos "lavar" e "molhar" que ocorrem com o substantivo "cabeça", é possível afirmar que os tradutores, Peter Bush e Clifford Landers, respectivamente, optaram pela manutenção da convencionalidade na língua inglesa, ao traduzirem "lavar a cabeça" e "molhando a cabeça" por "wash my hair" e "wetting his hair". Nos casos acima, os tradutores apenas preservaram a convencionalidade presente no original, optando por uma tradução não literal, contudo fluente e igualmente convencional na língua de chegada. 
Palavra de busca: Head

Head < Rosto

5.a ESTIT: I walked slowly along most of the dusty track, my head high, proud to feel the rain.

6.a ESTIT: I walk up and down on the grass, and, whichever way I go, the dead man's looking straight at me, without even turning his head round, looking like a mute television newscaster.

7.a ESTIT: The old caretaker is sleeping slumped awkwardly across the side of a chair, a red nylon windcheater hiding his head, and a plastic cap round hair that has just been dyed mahogany.

8.b ESTIT: He stops in front of a light reflector and suddenly twists his head towards me, pushing back the hair falling over his face, and asks 'What's the time?' but I'm in a $T$-shirt and it's obvious l've not got a watch. 5.b ESTPO: Andei sem pressa grande parte do caminho de barro, o rosto para o alto, orgulhoso de tomar chuva.

6.b ESTPO: Ando na relva para lá e para cá, e para qualquer lado que eu vá o morto me olha de frente, mesmo sem virar o rosto, parecendo um locutor de telejornal, mudo.

7.b ESTPO: O caseiro velho dorme rijo na diagonal de uma cadeira, um blusão de náilon vermelho cobrindo seu rosto, e uma touca de plástico prendendo seus cabelos recémtingidos de acaju.

8.a ESTPO: Pára diante de um panelão de luz e vira o rosto para mim num movimento abrupto, jogando para trás os cabelos que Ihe caíam na testa. Pergunta "que horas são?", mas estou de camiseta e é evidente que não uso relógio. 
9.a BENIT: He draws in his lips, lowers his head, shakes his shoulders, and Ariela begins to suspect that G. Gâmbolo rounded up Alyandro, his cousin, the photographer, the hair stylist, the secretary and maybe the heavily made-up pastor to go through the photos and make fun of her grimaces. 9.b BENPO: Retrai os lábios, baixa o rosto, sacoleja os ombros, e Ariela começa a suspeitar que G. Gâmbolo tenha convocado Alyandro, o primo, o fotógrafo, o cabeleireiro, a secretária e quiçá o pastor maquiado para manusearem suas fotos e debocharem dos seus trejeitos.

10.a BENIT: With her head out the window, she is aware that the driver has moved to the left of the seat and continues to stare at her.

10.b BENPO: Com o rosto para fora da janela, tem consciência de que o motorista cambou para a esquerda do assento e continua a fitá-la.

11.a BENIT: She sat in the front seat and turned her head while the bus filled with workers and maids.

11.b BENPO: Sentou-se no primeiro banco e virou o rosto quando o ônibus encheu-se de operários e empregadas domésticas.

12.a BENIT: If he could turn only his head, without anticipation of any kind, perhaps he would see before him Castana Beatriz's daughter.

12.b BENPO: Se ele conseguisse voltar o rosto sem qualquer pressentimento, quem sabe teria agora diae de si a filha de Castana Beatriz.

13.a BUDIT: I paused for long seconds, silences that only poets allow themselves, and he lowered his head, glanced sideways at his piles of books, and even piled them up on his lap as if about to leave. 13.b BUDPO: Eu fazia longas pausas, silêncios que só um poeta se permite, e ele baixava o rosto, olhava para os lados, para seus montes de livros, chegou a juntar os livros no colo, fez menção de se retirar. 


\section{Head < Pescoço}

14.a BENIT: He imagines the black taxi on his tail, which is surely foolishness, but he refuses to turn his head.

\section{Head <Queixo}

15.a BENIT: She had set out quickly but not too quickly, her head high, toward the outline of a street in the middle of the sand dunes.

16.a BENIT: he walks with head held high as her mother would have walked, ignoring the puddles, and making an improvised adornment of the canvas bag with which she protects her hair.

\section{Head $<$ Cara}

17.a BUDIT: Or Pisti sticking his head into the pantry and shouting something that sounded Turkish. 14.b BENPO: Imagina o táxi preto na sua cola, o que deve ser tolice, mas recusa-se a virar o pescoço. 15.b BENPO: Partiu ligeira, mas não muito, o queixo erguido, por um esboço de rua no meio do areal.

\begin{abstract}
16.b BENPO: Caminha de queixo erguido como caminharia a mãe, ignorando as poças, e da bolsa de lona com que protege os cabelos, faz um adereço casual.
\end{abstract}


todo: "cara", "queixo", "rosto" e "pescoço" são partes menores de uma unidade maior que é a "cabeça". O uso dessa figura de linguagem pelos tradutores confere às suas traduções uma fluidez que não seria possível caso os tradutores tivessem optado pela tradução literal. Nesses casos, os tradutores optaram pela manutenção da convencionalidade na língua de chegada.

Os exemplos apresentados a seguir, assim como os anteriores, mostraram que os três tradutores optaram por manter o aspecto convencional da linguagem, presente nos originais, em suas traduções. A tradução literal destes vocábulos poderia causar estranhamento ao leitor e até corromper o sentido da frase e não ofereceria ao leitor da língua inglesa a possibilidade de ter uma experiência de leitura semelhante à do leitor de língua portuguesa:

Palavra de busca : Back

\section{Back < ombros}

18.a ESTIT: She's wearing school uniform, a lunch-box strapped on her back and double-plaits.

\section{Back < barriga}

19.a BENIT: She sees herself on the diagonal of her intended path, and in front of her she sees Jeovan, lying on his back with the blanket up to his neck. 18.b ESTPO: Usa uniforme escolar, lancheira amarrada nos ombros e tranças de maria-chiquinha.

19.b BENPO: Vê-se na diagonal do rumo que visava, e à sua frente vê Jeovan, deitado de barriga para 0 alto e coberto até o pescoço. 


\section{Back < corpo}

20.a BENIT: Then Ariela turns her back, at which point she hears the rustling behind her cease.

\section{Back < dorso}

21.a BENIT: The woman says, 'The child was yours, you fool,' and begins to sob, but Zorza sees Ariela's back shuddering from top to bottom and suspects the sobs are hers.

\section{Hand < braço}

22.a BENIT: She tilts her head, tossing back her straight hair, extends her hand and hails a taxi with a single raised finger, a gesture that is the tunic's more than hers. 20.b BENPO: Então Ariela gira o corpo, com o que ouve cessar o farfalho às suas costas.

21.b BENPO: A mulher fala "o filho era teu, idiota" e começa a soluçar, mas Zorza vê o dorso de Ariela a sacudir-se de alto a baixo $e$ desconfia que os soluços sejam dela. 22.b BENPO: Volteia a cabeça, jogando para trás a lisa cabeleira, estica o braço e faz parar um táxi com o dedo em riste, num gesto que é da túnica, mais do que seu.

\section{Hand < pulso}

23. a BUDIT: I had taken it into my head that, if I were to manually copy them one by one, I would regain the hand for writing novels to order.

23.b BUDPO: Eu tinha encasquetado que, se os fosse copiando um por um à mão, recobraria o pulso para novos romances de encomenda. 


\section{Hand < punho}

23.a BUDIT: There I became initiated in the tongue in which I presume to write this book in my own hand, which would have been unimaginable seven years ago when I weighed anchor in Hamburg and entered Guanabara Bay.

\section{Mouth < bico}

24.a BENIT: Benjamin had seen the small bubbles that formed around her mouth and clotted to assume the shape of something like a cauliflower; then he had seen nothing, because the spittle hit him in the eyes.

\section{Mouth < lábios}

25. a BUDIT: I rumed the revolver to my ear, my heart, from one eye to the other, ran the barrel around my mouth like lipstick, and swallowed it again, determined to put an end to the game. 23.b BUDPO: Ali me iniciei na língua em que me arrojo a escrever este livro de próprio punho, o que seria inimaginável sete anos atrás, quando zarpei de Hamburgo e adentrei a baía de Guanabara.

24.b BENPO: Benjamim ainda viu as pequenas bolhas que se formavam no seu bico, e que se coalhavam, e que tomavam mais ou menos o aspecto de uma couve-flor, depois não viu mais nada porque a cusparada o atingiu dentro dos olhos.

25 b. BUDPO: Desviei o revólver para o ouvido, para o coração, para um olho e outro, fiquei passando a ponta do cano feito um batom nos lábios, até o engolir novamente, determinado a encerrar a brincadeira. 


\subsection{Expressões idiomáticas}

O segundo ponto evidenciado por meio da pesquisa no sentido IT - PO foi a presença de vocábulos como "eyes", "hand", "head", "mouth", "hair"e "back" em expressões idiomáticas que possuem como um de seus elementos linguísticos um desses vocábulos e que foram usadas na tradução de palavras ou expressões que não fazem parte do campo semântico investigado. Com o objetivo de ilustrar tal constatação, observa-se, dentre vários casos, que a expressão "take into one's head" foi utilizada como tradução do verbo "encasquetar". Portando, mais uma razão pela qual o número de ocorrências de alguns desses vocábulos em inglês é superior ao número de ocorrências de alguns desses vocábulos no português original. Os excertos abaixo ilustram esses fenômenos tradutológicos e evidenciam novamente o fato de que a convencionalidade na língua de chegada é priorizada nas traduções:

Palavra de busca: Back

26.a BUDIT: The portfolio was 26.b BUDPO: O book deveria me supposed to serve as servir de estímulo para retornar ao encouragement for me to return to trabalho: o alemão não sai do meu work: Look, mate, I can't get the pé, cara, tem que tocar o novo livro, German off my back, you've gotta eu até descolei um patrocínio... get the new book happening, I've even swung a sponsor...

A tradução literal da expressão idiomática "sair do meu pé" por "get off my foot' não traduziria corretamente o sentido da expressão em português: "deixar em paz". Em inglês a expressão idiomática que expressa essa ideia é "get off one's back". Desta forma, o substantivo "pé" contido na expressão em 
português foi substituído por "back", que significa "costas" em inglês. A tradução literal da expressão original soaria incomum em inglês e causaria estranhamento ao leitor. Ao substituir "pé" por "back" na expressão acima, a tradutora, Alison Entrekin, oferece ao leitor de língua inglesa a mesma experiência de leitura do leitor de língua portuguesa. Neste caso, como no exemplo abaixo, prevaleceram a manutenção do uso convencional da língua:

27.a BUDIT: I forwent the soup, left home with the shirt on my back and settled into the agency, where I enjoyed the company of my articles until I fell asleep on the sofa. 27.b BUDPO: Dispensei a sopa, abandonei o lar com a roupa do corpo e me ajeitei na agência, onde ficava namorando meus artigos até adormecer no sofá.

A expressão idiomática "como a roupa do corpo", se traduzida literalmente, não faria o mesmo sentido em inglês. Ao optar pelo uso da expressão idiomática "with the shirt on my back", a tradutora não só resgatou o significado da expressão em português como também recuperou a convencionalidade e a idiomaticidade do original.

Palavra de busca: Hair

28. aBUDIT: And the maid was singing, and the cook was whistling; when the lady of the house sleeps out the help will_let their hair down. I demanded that my son be taken to school and ordered an omelette and fresh peeled fruit, but they had not been to the market and the boy was on holiday.
28. b BUDPO: $\mathrm{E}$ a arrumadeira cantava, e a cozinheira assobiava, quando a patroa dorme na rua as empregadas se regalam. Mandei levar meu filho à escola, ordenei uma omelete $\mathrm{e}$ frutas frescas descascadas, porém não tinham feito a feira e o menino estava de férias. 
29.a BUDIT: But she wanted help with her dress, and as I did it up it I saw her skin form a slight fold, which the zip did not nip by a hair. 29.b BUDPO: Mas era para eu ajudá-la com o vestido, e ao fechálo, vi se formar em sua pele uma ligeira dobra, que o zíper por pouco não beliscou.

Palavra de busca: Hand.

A pesquisa feita a partir do vocábulo "hand" mostrou que Landers e Entrekin usaram, em suas traduções, a expressão idiomática "on the other hand" em substituição às locuções conjuntivas: "pelo contrário"; "ao contrário"; "por sua vez"; "em contrapartida" e "por outro lado". Bush e Entrekin optaram pelo emprego da expressão "on the one hand" para traduzirem a locução "por um lado". Embora as expressões "on the other hand" e "on the one hand", cujos significados se aproximam das locuções acima citadas, exerçam solidariamente a mesma função de ligar pensamentos que contrastam entre si, percebe-se, pela análise dos excertos acima, que ocorreu, por parte dos tradutores, uma padronização, sacrificando, de certa forma, a intenção estilística do autor, que optou pelo uso diversificado de locuções conjuntivas.

\section{ESTORVO}

30.a ESTIT - A rickety truck blows up dust as it speeds through the gate. A black-and-white truck banging along the dirt track, and it's the police. On the one hand, I want to throw myself in their path, wave my arms and shout 'I'm here!' On the other, I want to plunge into the bamboo thicket and that's what I do. 
30. b ESTPO - Levantando poeira, uma camionete caquética penetra a cancela.Uma camionete preta e branca sacolejando na estradinha de terra batida, e é a polícia. Eu, por um lado, quero me atirar no seu caminho, acenar com os dois braços e gritar "sou eu!". Por outro, quero mergulhar de cabeça no bambuzal, e é isso que faço.

\section{BENJAMIM}

31. a BENIT - But for Benjamin, on

the other hand, the hope had been reborn of seeing Castana Beatriz again.

32. a BENIT - Ariela, on the other hand, lost in thought as she descended that shaft, turns pale and takes shelter in the rear of the car.

\section{BUDAPESTE}

33.a BUDIT - The young man, on the other hand, commissioned a five-page essay on the Székely dialect.

\section{4.a BUDIT - On the other hand, however, once free of my entire Latin vocabulary, with Kriska's help I would learn to speak Magyar flawlessly.}

31.b BENPO - Para Benjamim, pelo contrário, renascia a esperança de reaver Castana Beatriz.

32.b BENPO - Ariela, ao contrário, que descia por aquele poço distraída, empalidece e ampara-se no fundo do cubículo. 33.b BUDPO - O rapaz por sua vez me encomendou uma dissertação de cinco laudas sobre o dialeto székely.

34.b BUDPO - Mas em
contrapartida, uma vez livre de
todo o vocabulário latino, com o
apoio de Kriska eu estaria apto a
falar um magiar castiço.
contrapartida, uma vez livre de todo o vocabulário latino, com 0 falar um magiar castiço. 
35.a BUDIT - She said that on the other hand she loved the cultural effervescence $i$ of the city and had been to scores of exhibitions.

36. a BUDIT - They both rose at the same time, herded me around the room, and while on the one hand he had muscles, fists and sharp rings, on the other, her face was more murderous. 35.b BUDPO - Disse que por outro lado adorava a efervescência cultural da cidade, tinha ido a um catatau de exposições.

36.b BUDPO - Ergueram-se os dois ao mesmo tempo, me acuaram em torno do quarto, e se por um lado ele ostentava músculos, punhos, anéis cortantes, por outro a cara dela era mais assassina.

As expressões idiomáticas a seguir, que possuem o vocábulo "hand" como um de seus elementos linguísticos, exemplificam o que foi constatado anteriormente, ou seja, que os tradutores, ao se depararem com expressões convencionais no português, fizeram opção pelo uso de expressões idiomáticas que recuperassem o sentido do original. A tradução literal nestes casos seria inadequada porque redundaria em expressões não convencionais na língua de chegada e o idiomatismo seria perdido e o significado do original talvez fosse deturpado. Portanto, presume-se os tradutores tenham levado em consideração a opção do autor pelo emprego de expressões convencionais para nortear suas decisões tradutórias.

37.a BUDIT: At the end of summer, I even bought an old portable typewriter and tried my hand at transcribing a few recordings to compare with the text of the minutes and assess my writing progress. 37.b BUDPO: No final do verão até comprei uma velha máquina portátil e me meti a transcrever algumas fitas, para cotejar com o texto da ata e avaliar meus progressos na escrita. 
38.a BUDIT: But I had the upper

hand; with my tercets on the tip of my tongue, I was declaiming the Apotheosis of the Poets and knew he would remain seated until the end.

39.a BUDIT: I could even leave that night, if it were possible, seeing as I already knew Buda like the back of my hand and had a whole day for Pest.

40.a BUDIT: In the closing session there were speeches in defence of the rights to privacy and freedom of expression, but the proposal to write an open letter was dismissed out of hand; after all, no newspaper would publish a petition signed by writers who never sign. 38.b BUDPO: Mas eu estava a cavaleiro, com meus tercetos na ponta da língua, eu estava declamando a Apoteose dos Poetas e sabia que ele quedaria sentado até o fim.

39.b BUDPO: Poderia até embarcar naquela noite, se calhasse, visto que Buda eu já conhecia de cor, e para Pest tinha um dia inteiro.

40.b BUDPO: $\mathrm{Na}$ sessão de encerramento houve discursos em defesa dos direitos de privacidade e livre expressão, mas a proposta de se redigir uma carta aberta foi de pronto rechaçada; afinal, jornal algum publicaria um abaixoassinado de escritores que nunca se assinam.

41.b ESTPO: Chego à rodoviária com uma bolada em cada bolso da calça, quatro tijolos de notas miúdas, que o caixa do banco encasquetou de me trocar $o$ cheque assim. 
42.a BUDIT: I had taken it into my head that, if I were to manually copy them one by one, I would regain the hand for writing novels to order.

42.b BUDPO: Eu tinha encasquetado que, se os fosse copiando um por um à mão, recobraria o pulso para novos romances de encomenda.

43.a BUDIT: The fellow glanced at my window from time to time and I got it into my head that he was also waiting for Vanda.

44.a BUPIT: One day, with Kriska pressed against my chest in the packed carriage, without her asking me anything, I got it in my head to pronounce the word szivem. 43.b BUDPO: O tipo olhava de tempo em tempo para a minha janela, e cismei que ele também estaria à espera da Vanda.

44.b BUDPO: Num destes dias, tendo Kriska colada em meu peito no vagão lotado, sem que ela me perguntasse nada, me deu na veneta pronunciar a palavra szívem.

45.a BUDIT: By now the Cunha \& Costa Cultural Agency was established in an office suite overlooking Copacabana Beach, and Álvaro took it into his head to frame and hang what he considered my best work.

45.BUDPO: A Cunha \& Costa Agência Cultural já estava então estabelecida em três ambientes com vista para a praia de Copacabana, e o Álvaro inventou de emoldurar e pendurar nas paredes as minhas obras de sua predileção.

46.b BUDPO: Depois deu para ter ciúme, deu para me recusar seu corpo, disse que eu só a procurava a fim de escrever nela, e o livro já ia pelo sétimo capítulo quando ela me abandonou.

46. BUDIT: Later she took it into her head to get jealous, to refuse me her body, saying I only wanted her to write on, and the book was already in the vicinity of chapter seven when she abandoned me.

As expressões "get into one's head" e "take into one's head" foram usadas na tradução do verbo "encasquetar" pelos tradutores Bush e Entrekin. 
Esse verbo de uso coloquial em português, que significa "meter na cabeça", está semanticamente relacionado ao vocábulo "head", pois implica o processo mental de fixação de uma ideia. A sutil alternância entre os usos dos verbos "get" e "take" nas expressões acima não provocou mudança de sentido na tradução com relação ao original. Supostamente, na ausência de um verbo em inglês que traduzisse o mesmo sentido com equivalente teor de informalidade no português, os tradutores Bush e Entrekin optaram pelo uso das referidas expressões de uso coloquial com o provável intuito de resgatar o coloquialismo do verbo "encasquetar" e recuperar a sentido por ele expressado.

Dito isso, pode-se afirmar que os tradutores, nesses casos, recuperaram o sentido e o estilo informal da escrita, recorrendo ao uso de uma expressão idiomática que substituísse satisfatoriamente o sentido do verbo "encasquetar".

Nos excertos acima apresentados, o verbo "cismar" e as expressões "dar na veneta", "inventar de" e "dar para", em seus respectivos contextos, foram traduzidos pelas mesmas expressões dos exemplos acima: "get something into someone's head" ou "take something into someone's head". Nesses casos, embora a tradutora tenha recuperado o sentido e, de certa forma, o coloquialismo do original, ela optou por condensar uma variedade de opções lexicais do autor em duas expressões bastante semelhantes. É possível afirmar que a intenção estilística do autor foi, em parte, sacrificada nos casos acima mencionados.

Como foi dito, a análise feita no sentido inverso (IT - PO) revelou pelo menos duas razões que justificam as discrepâncias entre os números de ocorrências de alguns dos vocábulos selecionados para análise. O estudo desses casos mostrou que os tradutores optaram pela a manutenção da 
convencionalidade na língua de chegada. Em alguns casos essa opção se fez necessária para recriar o sentido do original na tradução, e preservar a suposta intenção estilística do autor como, por exemplo, nas traduções das expressões idiomáticas acima arroladas. Em outras situações a opção do tradutor pelo uso de uma única expressão de uso convencional da língua de chegada em substituição a uma pluralidade de palavras sinônimas, - como os casos (33, 34, 35) nos quais a expressão "on the other hand" foi usada três vezes na tradução das seguintes locuções conjuntivas: "por sua vez"; "em contrapartida"; "por outro lado" - não restituir, neste caso específico, a diversidade lexical presente no texto original.

Essas verificações empíricas acerca das traduções analisadas trazem à tona a tese defendida por Umberto Eco (2007, p. 19), de "que a tradução se apóia em alguns processos de negociação, sendo a negociação, justamente, um processo com base no qual se renuncia a alguma coisa para obter outra". E, complementando seu raciocínio acerca do assunto, Eco afirma que, no final, as partes envolvidas deveriam sair razoavelmente satisfeitas "à luz do áureo princípio de que não se pode ter tudo."

\subsection{Colocados criativos: Quando "os olhos fogem do assunto".}

Como explicado no capítulo anterior, foram selecionados para análise as palavras-chave pertencentes ao campo semântico do corpo humano: "olhos"; "mão"; "cabeça"; "boca"; "cabelos"; "costas" e suas respectivas traduções: "eyes"; "hand"; "head"; "mouth"; "hair" e "back". As referidas palavras-chave em português figuram entre as cem primeiras das listas de palavras-chave com índice de chavicidade igual ou superior a 50, e estão presentes nas três obras 
analisadas e em suas respectivas traduções. Ficou estabelecido também, como critério de análise, que elas seriam examinadas e comentadas levandose em conta os seus colocados, ou seja, as palavras que as acompanham, como por exemplo, verbos ("fechei os olhos - I closed my eyes") e adjetivos ("olhos negros - black eyes") ou outro substantivo ("ruído de olhos" - sound of eyes").

Dentre as palavras-chaves acima citadas e seus colocados, selecionaram-se para análise as combinações menos convencionais e, portanto, mais criativas. Como visto no Capítulo III, a criatividade linguística pode ser resultado da quebra intencional da convencionalidade pelo autor. Tais manipulações linguísticas, que são típicas da linguagem literária, tendem a impor problemas de traduções. Pois, como afirma Lefebve (1980, p. 14), "o discurso literário é sempre, numa certa medida, inadequado, gratuito, dotado de uma espécie de opacidade." A obra literária é multi facetada e policêmica, é lugar de uma dupla intenção e por esse motivo tende a impor grandes desafios àqueles que assumem a empreitada de traduzi-la.

Passa-se agora à análise de excertos que exemplificam algumas das combinações criativas envolvendo as palavras-chave pesquisadas:

47.a. BUDPO: Kriska, porém olhou para baixo, para os lados, para a janela, os anúncios, o túnel, seus olhos fugiram do assunto.
47.b.BUDIT: Kriska, however, looked down, to the sides, at the window, the advertisements, the tunnel, her eyes avoiding the topic.

A colocação "fugir do assunto" é comum, faz parte de nosso discurso cotidiano e, apesar de possuir certo grau de idiomaticidade, o seu significado pode ser considerado transparente. Contudo, as pesquisas realizadas no 
Corpus Brasileiro e Cdp sinalizam que o sujeito é sempre pessoa. Tal informação corrobora a suspeita de que "seus olhos fugiram do assunto" tratase de uma construção inusitada, em que o autor fez um jogo de palavras e de sentidos, A criatividade do escritor, Chico Buarque, reside justamente na sua capacidade de transformar uma expressão corriqueira como "fugir do assunto" em algo poético e singular, ao atribuir aos "olhos" a capacidade de se esquivar de uma conversa indesejada.

A colocação "avoid the topic" é bastante convencional na língua inglesa, revela pesquisa realizada no corpus COCA. Entretanto, não há ocorrências onde a palavra "eyes" apareça seguida de "avoid the topic". Portanto, ao examinar a tradução, concluiu-se que a tradutora não só recriou essa bela imagem metafórica, mas recuperou a manipulação linguística do autor ao traduzir "seus olhos fugiram do assunto" por "her eyes avoiding the topic."

48.a BENPO: Agora o sol bate em cheio no seu rosto, e os globos dos seus olhos saracoteiam por baixo das pálpebras. 48.b BENIT: Now the sun hits him squarely in the face, and his eyeballs dance under his lids.

O verbo "saracotear" cujos significados, segundo o Novo Dicionário Aurélio da Língua Portuguesa (1986, p.1552), são "menear o corpo, os quadris com desenvoltura e graça" e "vaguear por um lugar e por outro", foi usado no contexto acima para descrever a ação dos "globos dos olhos". Trata-se de uma combinação inusitada ${ }^{128}$ entre "globos dos olhos" e o verbo "saracotear". Nas ocorrências examinadas no Corpus Brasileiro, o verbo "saracotear" sempre

\footnotetext{
${ }^{128}$ Não foi encontrada nenhuma ocorrência dessa combinação nas 12 ocorrências registradas no Corpus Brasileiro, tendo como palavra de busca o verbo "saracotear". Dentre essas 12 ocorrências nenhuma pertence ao gênero textual literário. $O$ mesmo resultado foi obtido quando a pesquisa foi realizada no Cdp.
} 
aparece acompanhado de sujeitos representados por pessoas, como nesta frase extraída de uma das doze ocorrências que lá aparecem: "Não é preciso parceiro fixo para saracotear em um forró."

Pode-se dizer que a tradução desta combinação criativa, "os globos de seus olhos" com o verbo "saracotear", em "os globos dos seus olhos saracoteiam por baixo das pálpebras", por "his eyeballs dance", em "his eyeballs dance under his lids" está semanticamente adequada e descreve os movimentos dos globos dos olhos do personagem. Contudo, o verbo "dance", além de não possuir as mesmas variáveis semânticas do verbo "saracotear" cujo significado vai além do ato de dançar, contendo referências culturais ao gracioso jeito brasileiro de dançar com ginga -, quando usado acompanhado de "eyeballs" não forma uma combinação tão engenhosa quanto o original. Portanto, é possível afirmar que neste caso a criatividade da já citada combinação no original foi parcialmente recriada na tradução.

49.a. ESTPO: Mas mesmo aquilo que a gente não se lembra de ter visto um dia, talvez se possa ver depois por algum viés da lembrança. Talvez dar órbita de hoje aos olhos daquele dia. 49.b ESTIT: But what you can't remember seeing one day, perhaps you can see later through some bias of memory. Perhaps by giving today's focus to that day's eyes.

O protagonista anônimo de Estorvo, ao refletir sobre os mecanismos cerebrais de suas lembranças, usa "olhos daquele dia" para se referir aos eventos e às suas experiências vividas no passado e a expressão "dar órbita de hoje" para atualizar a sua ótica sobre essas vivências e fatos ocorridos 
anteriormente. A tradução literal ${ }^{129}$ dos "olhos daquele dia" por "that day's eyes" recuperou com esmero a intenção criativa do autor no nível semântico ${ }^{130}$.

A tradução do substantivo "órbita", cujo sentido biológico refere-se à cavidade óssea da face, em que está situado o olho, pelo substantivo "focus" recuperou a criação do campo semântico relacionado ao olhar. Vale ressaltar que o substantivo feminino "orbif" também se refere à cavidade ocular e, portanto, poderia ter sido usado pelo tradutor em substituição à "órbita". Tal escolha certamente causaria estranhamento ao leitor da língua de chegada neste contexto, no entanto recuperaria a criatividade do autor. Portanto, podese afirmar que, mesmo tendo o tradutor privilegiado o aspecto convencional da língua de chegada, houve a intenção de oferecer ao leitor de língua inglesa o mesmo efeito do original.

50.a ESTPO: Logo na entrada há um segurança dentro de uma cápsula de aço, seus olhos como um casal de peixes gravitando no visor.

50.b ESTIT: Right in the entrance is a security guard inside a steel capsule, his eyes bobbing like a couple of fish behind the visor.

No trecho acima, o autor compara os "olhos" do segurança com um casal de peixes, que "gravitam" no visor de uma cápsula de aço. Seus movimentos são representados por "gravitar", um verbo de sentido relacionado à física, como consta do Novo Dicionário Aurélio da Língua Portuguesa (1986, p. 867): "tender para um ponto ou centro pela força da gravitação, ou andar à volta de um astro, atraído por ele". O emprego do substantivo "olhos" na

${ }^{129}$ Entende-se por tradução literal aquela em que, segundo Aubert (1987, p.15) 'se mantém uma fidelidade semântica estrita, adequando, porém a morfo-sintaxe âs norma gramaticas da LT".

${ }_{130}$ Os únicos quatros resultados encontrados a partir da busca feita pela expressão "dar órbita de hoje" foram esses contidos em Estorvo. 
companhia do verbo "gravitar" (ex.: "seus olhos como um casal de peixes gravitando no visor.") pode ser considerada rara, levando-se em conta o fato de que não há ocorrências dessa combinação registradas no Corpus Brasileiro.

Outra pesquisa realizada no Cdp corrobora a afirmação de que se trata de uma combinação incomum, pois não há registro dessa colocação no referido corpus.

No que concerne à tradução, ao optar pelo verbo "bob" ("his eyes bobbing like a couple of fish behind the visor") para descrever a movimentação de "eyes", onde havia a possibilidade de se usar o verbo "gravitate", o tradutor acaba por construir uma nova metáfora, ao empregar o verbo "bob", cujo significado descreve o movimento que se faz para cima e para baixo, algo a flutuar na água ${ }^{131}$. A combinação do substantivo "eyes" com o verbo bob no contexto acima (eyes bobbing) aparece em uma única ocorrência ${ }^{132}$ na pesquisa realizada no corpus COCA, revelando, portanto, que se trata de uma colocação também infrequente na língua inglesa.

Portanto, feitas as considerações acima, é possível afirmar que a imagem metafórica não só foi recuperada na tradução como também reelaborada, acrescentando significado ao texto.

51.a BUDPO: Atravessei a sala dos rapazes, e foi tamanho o silêncio deles que julguei escutar um ruído de olhos a me seguir.

51.b BUDIT: I crossed the lads' office and their silence was so great that I thought I heard the sound of eyes following me.

\footnotetext{
${ }^{131}$ De acordo com o dicionário Collings Cobuild (2003, p.146), "If something bobs, it moves up and down, like something does when it is floating on water."

${ }^{132}$ Esta única ocorrência não consta da seção de livros de ficção, mas de uma revista sobre esportes: "His eyes are bobbing and weaving like a driver traveling down a lonely, winding road at night, anxious over what he might meet around the next corner". Sporting News, Larry Wigge, Quick thinking, Vol. 224, Iss. 24; pg. 12, 3 pgs, 2000 (Jun)
} 
No seguimento acima, essa bela imagem, criada a partir da combinação incomum "ruído de olhos"133, foi traduzida por "the sound of eyes"134, que também é rara na língua inglesa. A grande expressividade alcançada pelo autor nessa passagem, dada por essa combinação tão peculiar, foi integralmente restituída na tradução.

52.a BENPO: Da calçada oposta, junto às palmeiras do parque, Ariela escala a fachada com os olhos em ziguezague, e encontra o décimo andar inteiramente às escuras.

52.b BENIT: From across the street, near the palm trees in the park, riela scales the building's façade with her eyes, zigzagging until she finds the tenth floor, completely dark.

53.a BUDPO: Sentei-me na ponta do banco ao lado dos seus pés e conferi a capa mostarda de $O$ Ginógrafo, que ela lia com os olhos em ziguezague.

53.b BUDIT: I sat on the end of the bench next to her feet and saw that it was indeed the mustard cover of The Gynographer, which she read with zigzagging eyes.

${ }_{133}^{133}$ Não foi encontrado nenhum registro da combinação "ruído de olhos" no Corpus Brasileiro.

${ }^{134}$ Há um registro de "sound of eyes" disponível no COCA. 
Nota-se uma reincidência lexical nos romances Benjamim e Budapeste: o autor usou de forma bastante criativa a expressão "em ziguezague" para descrever o movimento dos olhos dos personagens Ariela e José Costa. É interessante observar que as consultas feitas aos corpora Corpus Brasileiro e COCA revelaram que as palavras "ziguezague" e "zigzag" são muito pouco usadas em obras literárias. Dentre as 313 ocorrências de "ziguezague" no Corpus Brasileiro, apenas duas fazem parte do gênero literário; o corpus COCA também registra uma grande discrepância neste sentido, isto é, das 497 ocorrências de "zigzag", somente 26 estão classificadas na seção de livros de ficção. Outra constatação foi de que não há registro de ocorrência das combinações de "olhos" com "ziguezague" e nem de "eyes" com "zigzag" ou "zigzagging", nos corpora consultados. Portanto, é possível afirmar, que a combinação "olhos em ziguezague" e suas respectivas traduções ("eyes zigzagging" e "zigzagging eyes") são únicas nos referidos contextos de pesquisa. As imagens projetadas na mente do leitor pela escalada "da fachada com os olhos em ziguezague" e pela leitura do livro "com os olhos em ziguezague" resultam de uma hábil construção linguística realizada pelo autor, tendo sido recriadas com a mesma destreza pelos dois tradutores.

54.a ESTPO: Cai sentado na 54.b ESTIT: He slumps down on the cadeira ao lado, e seus olhos chair next to me, his eyes bleary voltam a se encharcar, desta vez this time with bitter tears. com lágrimas azedas.

Neste contexto, onde os "olhos voltam a se encharcar", assim como no anterior, em que os "olhos se inundaram", observa-se a recorrência do uso da hipérbole como um recurso lingüístico, para passar uma impressão de exagero. 
A suspeita de que se está diante de uma colocação criativa foi comprovada pelas consultas realizadas ao Corpus Brasileiro, que revelou duas únicas ocorrências dessa colocação. Essas ocorrências, que aparecem repetidas no corpus, são as mesmas do excerto acima extraído do romance Estorvo, e ao Cdp, onde não há ocorrências de "olhos" na companhia do verbo "encharcar" em sua forma original. Cabe ressaltar que embora a colocação mais usual, "olhos encharcados", fora encontrada nos dois Corpora consultados ${ }^{135}$, a combinação do substantivo "olhos" com o verbo "encharcar" é, de fato, uma colocação única no escopo pesquisado.

Nesse contexto, a criatividade, baseada na manipulação linguística, tornou-se ainda mais evidenciada pela colocação "lágrimas azedas". Como era de se esperar, devido ao fato de a referida colocação fazer parte da mesma sentença onde aparece "olhos voltam a se encarchar", foram encontradas pelo menos duas ocorrências repetidas no Corpus Brasileiro, ambas contidas em Estorvo. Entretanto, no Cdp não há ocorrências da colocação "lágrimas azedas", tratando-se, pois, de de uma colocação inventiva do autor.

Na tradução, o verbo "encharcar" foi substituído pelo adjetivo "bleary", cujo significado usual ("turvo, lacrimejante e remeloso") não reproduz a impressão de abundância presente no original. Embora o referido adjetivo tenha uma vizinhança de sentido com o verbo "encharcar" no contexto acima, a colocação "eyes bleary" não restitui a intenção criativa do original. Além disso, essa colocação, ao contrário de "olhos" que "voltam a se encharcar", é de uso

\footnotetext{
${ }^{135}$ No Corpus Brasileiro há dois registros repetidos de "olhos encharcados" acompanhados do substantivo "amor", e no Cdp há duas ocorrências de "olhos encharcados", das quais apenas uma aparece acompanhada do substantivo "lágrimas".
} 
comum em textos literários de língua inglesa, como aponta a pesquisa realizada no corpus COCA $^{136 .}$

Outro aspecto a ser tratado na análise da tradução deste excerto relaciona-se com a quebra intencional da convencionalidade do autor na colocação "lágrimas azedas", que não foi recuperada na tradução, pois o tradutor optou pelo uso convencional da colocação "bitter tears" ${ }^{137]}$ equivalente a "lágrimas amargas". Estendeu-se a pesquisa para verificar o número de ocorrências da colocação "lágrimas amargas", que intuitivamente soa mais usual. Os resultados mostraram catorze ocorrências no $\operatorname{Cdp}^{138}$ e quinze no Corpus Brasileiro. Portanto, acredita-se ser possível afirmar que existe uma correlação entre os níveis de convencionalidade das colocações "lágrimas amargas" e "bitter tears".

Concluindo, acredita-se que uma possível forma de se resgatar a intenção criativa do autor, por meio da quebra da convencionalidade, seria pelo uso do adjetivo "acid" no lugar de "bitter", pois a colocação "acid tears" 139 é incomum e, certamente, causaria estranhamento ao leitor da língua de chegada, criando o mesmo efeito do original.

\footnotetext{
${ }^{136}$ Há um total de setenta e duas ocorrências das colocações "bleary eyes" (trinta e nove) e "eyes bleary" (trinta e três) no referido corpus. Das setenta e duas ocorrências, cinquenta e quatro são oriundas de textos ficcionais.

${ }^{137[4]}$ Há um total de quarenta e três ocorrências da colocação "bitter tears", das quais vinte e sete são oriundas de textos ficcionais.

${ }^{138}$ Sendo doze dessas ocorrências em contextos literários no Cdp, mas nenhuma ocorrência em contexto literário no Corpus Brasileiro.

${ }^{139}$ A pesquisa realizada no COCA mostra um único registro dessa colocação no seguinte trecho: "I felt the anger slowly make its way to the surface until acid tears choked the back of my throat."
} 
55.a BUDPO: Portanto quedei na expectativa de novas palavras, mas ela tomou impulso e partiu realmente como uma flecha, sua cabeça sobrevoando as estantes centrais da livraria. 55.b BUDIT: I thus expected new words, but she sprang into motion and literally darted away like an arrow, her head flying over the centre shelves of the bookshop.

Este trecho da obra é marcado pelo deslocamento rápido da personagem, que é caracterizado pelo emprego dos verbos de movimento presentes na frase ("partir" e "sobrevoar"). A imagem metafórica da "cabeça" passando velozmente pelas "estantes centrais da livraria" foi super valorizada pelo uso do verbo "sobrevoar", que geralmente tem como sujeito máquinas voadoras, as pessoas que as conduzem ou que nelas são transportadas, como mostra o exemplo extraído do Corpus Brasileiro: "um pequeno aparelho do aeroclube de Santa Fé começou a sobrevoar a cidade a uns mil metros do solo". A combinação do substantivo "cabeça" com o verbo "sobrevoar" é única no âmbito dos corpora Cdp e Corpus Brasileiro.

A tradução do trecho acima, por sua vez, resgata a intenção criativa do autor, ao recriar na língua de partida uma combinação também singular no inglês. Não há registro de ocorrências do substantivo "head" como sujeito de "fly over" no corpus COCA. Na pesquisa realizada nesse corpus de língua inglesa, encontrou-se o substantivo "head" na no seguinte exemplo: "The woman kicked off her shoes - both flying over the heads of the circle and landing by the piano (...)"140, mas não como o sujeito do verbo. Há de se mencionar o registro, no referido corpus, de uma imagem metafórica, onde "fly over" veio acompanhado de um sujeito diferenciado, ou seja, que não é nem

\footnotetext{
${ }^{140}$ SHAPIRO, Dani. Slow motion a true story. San Diego: Harcourt Brace, Edition: $1^{\text {st }}$ Harvest ed., 1999.
} 
máquina, nem pessoa, mas parte dela, o substantivo "fingers" (dedos) : "I have listened to her play Liszt etudes and Chopin nocturnes, watched her graceful fingers flying over the keys, (...) her brow furrowed in concentration as she transformed notes on a page into something that moved me".

Nestas construções criativas ("cabeça sobrevoando" e "head flying over") a coesão semântica foi substituída por uma coesão condicionada pelo contexto da frase em ambas as línguas. Afinal, no sentido literal, cabeças não são dotadas da capacidade física de voar ou, neste caso, de sobrevoar objetos.

56.a BUDPO: Eu tinha alinhavado na cabeça um texto sincero em meus sentimentos por ela, além de rápida explicação para a minha partida. 56.b BUDIT: I had tacked together a text in my head that was sincere in my feelings for her, I as well as a quick explanation for my departure

Neste trecho o autor recorre à colocação "alinhavar um texto" para se referir à construção de um texto. É comum entre as pessoas familiarizadas com o processo de elaboração textual associar esse tipo de criação ao sentido figurado de costurar, de tecer as tramas um texto, comparando a criação do autor à de um artesão. Contudo, o substantivo "cabeça" não é comumente usado com a colocação "alinhavar um texto". Talvez, por se tratar de uma atividade intelectual, o uso do substantivo "cabeça" pode parecer supérfluo e, porque não dizer, gratuito, no contexto acima. Mesmo assim, o autor, intencionalmente, explicita o local onde ocorre essa tessitura mental, criando 
certo estranhamento ao leitor, pois rompe com o "jeito"141 cotidiano de se expressar metaforicamente a ideia de se compor um texto.

Sobre a tradução, a metáfora do original ("alinhavado na cabeça um texto"), foi recriada pela tradutora ("tacked ${ }^{142}$ together a text"), pois seu significado reúne os mesmos traços semânticos da expressão original. Assim como no texto original, o uso do substantivo "head" não seria necessário para compor o sentido da frase. Contudo, a tradutora recupera a intenção estilística do autor ao traduzir "cabeça" por "head", oferecendo ao leitor de língua inglesa a mesma possibilidade de leitura do leitor de língua portuguesa.

Considera-se pertinente informar que a pesquisa realizada no corpus COCA mostrou que das 322 ocorrências de "tacked", apenas duas foram seguidas da palavra "together"143, formando a colocação "tacked together". Contudo não há registros nesse corpus de ocorrências do substantivo "text"' na condição de objeto dessa colocação. Portanto, pode-se acreditar que "tack together a text' não é uma metáfora consagrada na língua inglesa, e que foi criada pela tradutora a partir da expressão "alinhavar um texto". Dito isto, seria desnecessário dizer que não há registro de ocorrências do substantivo "head" nos contextos pesquisados. Tais fatos ratificam a afirmação feita anteriormente, de que as intenções semânticas e estilísticas do autor foram recriadas pela tradutora, demonstrando um esforço tradutório comprometido em resgatar aquilo que o autor supostamente quis dizer.

\footnotetext{
${ }^{141}$ O uso da palavra "jeito" no contexto acima é uma alusão ao título do livro "O jeito que a gente diz", de Tagnin (2005).

${ }_{142} \mathrm{O}$ dicionário Collins Cobuild (2003, p.1473), apresenta a seguinte definição para o verbo "tack" : "if you tack pieces of material together, you sew them together with big, loose stitches in order to hold them firmly or check that they fit, before sewing them properly."

${ }^{143}$ Não há registros de "tack together" no corpus COCA (grifo do pesquisador).
} 
57.a BENPO: Não é mais Castana Beatriz, é Ariela, como Benjamim a viu pela primeira vez, mas hoje cara a cara, a sua íntima boca escancarada, uma mulher estupenda, lembrando vagamente a mãe, mas um pouco vulgar, e portanto uma mulher por quem qualquer um gostaria de padecer. 57.b BENIT: She is no longer Castana Beatriz, she is Ariela, as Benjamin saw her that first time, but now face to face, her intimate mouth open wide, a stupendous woman, vaguely recalling her mother, but a trifle more common, and therefore a woman for whom any man would be glad to suffer.

No trecho o substantivo "boca" veio acompanhado de dois adjetivos: precedido de "íntima" e seguido de "escancarada". No primeiro caso, a ocorrência do adjetivo "íntima" com o substantivo "boca" forma uma combinação que é muito pouco comum em nosso idioma, principalmente na ordem em que se apresenta no texto. Drummond, no poema Nudez ${ }^{144}$, fala em boca "ensimesmada", cujo significado é parecido com "íntima", mas a combinação "íntima boca" parece ser uma singularidade de Chico Buarque, considerando os resultados das pesquisas realizadas no Corpus Brasileiro e no Cdp, que não apontaram nenhuma ocorrência dessa combinação. No segundo caso, a ocorrência do substantivo "boca" com o adjetivo "escancarada" não é tão incomum, há registro dessa combinação no Corpus Brasileiro.

Transferindo o foco desta análise lexical para a tradução, é possível afirmar que ela recria o jogo com as/ de palavras proposto pelo autor. Ao usar o adjetivo "intimate" coligado ao substantivo "mouth", o tradutor recria, a partir do português, o ineditismo dessa combinação, pois não há registros de "intimate mouth" no corpus COCA. Já a locução "open wide" aparece com maior frequência na companhia do substantivo "mouth", embora o seu uso não seja

${ }^{144}$ ANDRADE, C. Drummond de. Obras Completas. In: Nudez. São Paulo: Abril Cultural, 
tão comum, das 35 ocorrências de "open wide" registradas no corpus COCA, apenas 4 ocorrem na companhia de "mouth".

O conjunto desses elementos linguísticos: "íntima boca escancarada" e "intimate mouth open wide", em uma análise superficial causa estranhamento e soa em certa medida inadequado, mas olhando mais de perto percebe-se a riqueza semântica e estilística nele contida.

58.a BENPO: Caminha devagar, mas usa um batom de um grená tão impetuoso, que a sua boca parece vir dois passos adiante. 58.b BENIT: She walks slowly, but she is wearing garnet lipstick so brash that it seems to move two steps ahead of her.

No texto original, a metonímia formada pelo emprego da palavra "boca", que "parece vir a dois passos adiante", está relacionada à personagem, que "caminha devagar". Já na tradução, o tradutor substituiu o substantivo "boca" pelo pronome "it", que tem como elemento de referência o substantivo "lipstick" (batom), recriando uma imagem diferente do original. Não há dúvida de que a metonímia criada pelo tradutor é também um exercício de criatividade linguística, contudo difere da intenção original do autor, pois, no texto original, é a "boca" e não o "batom" na boca que parece chegar primeiro que a personagem> Assim, houve uma mudança do foco projetado na imagem recriada pelo tradutor.

Ainda no campo lexical, embora extrapolando um pouco o escopo da análise que, neste contexto, restringe-se ao exame da tradução da palavrachave "boca" e das palavras vizinhas diretamente relacionadas a ela, observase que o autor do original usou o adjetivo "impetuoso" para caracterizar a cor 
"grená" do batom usado pela personagem, um adjetivo geralmente empregado para qualificar um comportamento humano, assim como o adjetivo "brash", mas que em ambas as línguas, no contexto acima, referem-se à intensidade da referida cor. Contudo, o adjetivo "brash" possui uma prosódia um tanto negativa. Uma pesquisa realizada no corpus COCA mostrou que, em sua acepção mais comum, ele é usado para descrever uma atitude humana demasiadamente confiante, precipitada e agressiva. Portanto, o tradutor poderia ter optado pelo uso do adjetivo "impetuous", que remete o leitor a outros sentidos da palavra relacionados à paixão e fogosidade.

Cabe ressaltar que, na tradução, a sintaxe da frase foi modificada em decorrência da mudança do elemento de referência, ou seja, no original a oração “(...), mas usa um batom de um grená tão impetuoso, (...)” é intercalada: ela explicita o motivo pelo qual a "boca", a parte que representa o todo, parece vir à frente da própria personagem, ou seja, existe uma pausa no original que não foi considerada na tradução. Desta forma o ritmo do original não foi recuperado na tradução.

59. a BUDPO: Respondi que ia ver, tinha alguns afazeres no Rio, assuntos pendentes, perguntei se a passagem era de primeira classe, mas minha cabeça já alçava vôo, meus pensamentos vinham em versos.
59. b BUDIT: I could leave that very night, I said I would see, I had a few things to tend to in Rio, pending affairs; I asked if the ticket was first class, but my head was already lifting off my thoughts came in verses.

Neste trecho de Budapeste o autor prima pela construção de um campo semântico relacionado ao ato físico de viajar a bordo de um avião e a uma 
viagem mental conduzida pelos "pensamentos" que "vinham em versos". Chico Buarque constroi esta imagem metafórica usando uma combinação não convencional e bastante criativa: "minha cabeça já alçava vôo". Nesta passagem do romance, a sua criatividade é marcada pela manipulação do léxico. O autor rompe com a convencionalidade ao usar o substantivo "cabeça" como sujeito do verbo "alçar" (na expressão "alçar vôo"). Não há registros dessa combinação nos corpora consultados (Cdp e Corpus Brasileiro).

Entretanto, cabe mencionar que o Cdp registra um único uso da colocação "alçar vôo", cujo sentido está relacionado a um processo mental, mas a palavra que a acompanha é o substantivo "pensamento" (ex. "O quadro edificante completa-se, como é de regra, com uma caveira e uma cruz de pau, sem as quais nenhum pensamento poderá alçar seu vôo às supremas alturas". ${ }^{145}$ ). Já o Corpus Brasileiro registra o uso figurado da colocação "alçar vôo", com esse mesmo sentido, em algumas de suas noventa e duas ocorrências: ex: “(...) embora partindo de condições concretas, o pensamento humano consegue alçar vôo.", "A imaginação não consegue alçar vôo. (...) não existe pensamento sem referência a uma prática (...)." Portanto, neste caso, a criatividade no nível lexical reside na habilidade linguística do autor em criar combinações não usuais.

Referindo-se à tradução, é possível afirmar que a intenção criativa do autor foi integralmente recriada na medida em que o phrasal verb "lift off' não ocorre usualmente com o substantivo "head"; trata-se de uma combinação também incomum na língua inglesa: "my head was already lifting off'. Das 387 ocorrências de "lift off' no COCA, não foi encontrada uma única em que o

${ }^{145}$ Trecho extraído da obra O conto do diabo e as pedras, de José Saramago. 
substantivo "head" apareça como seu sujeito. A mesma pesquisa mostrou uma ocorrência do phrasal verb "lift off", cujo significado está relacionado a uma viagem mental (e.g. "She sits across from him at the table, staring. " Smoke some dope. Lift off, just for an hour. Look down on the everyday shit' $\left.{ }^{146}\right)$. Portanto "lift off", assim como "alçar vôo", é também usado no sentido metafórico para expressar a ideia de se desprender das coisas terrenas e deixar a imaginação fluir.

60.a BENPO: Com olhos trinta anos mais velhos, Benjamim reproduz a ouro e fio a Castana Beatriz que um dia conheceu numa sessão de fotos.

60.b BENIT: With eyes thirty years older, Benjamin reproduces exactly the Castana Beatriz that he met one day in a photo session.

${ }^{146}$ Trecho extraído do romance "The things we do to make it home", Gologorsky, Beverly. New York: Random House, 1st ed., 1999. 
Neste trecho, Benjamim Zambraia, o protagonista da obra homônima, reproduz, após um lapso de trinta anos, a imagem de Castana Beatriz, o grande amor de seu passado. O emprego do substantivo "olhos" aliado a uma expressão temporal com 0 intuito de representar 0 amadurecimento/envelhecimento de um indivíduo é incomum/inédito, considerando-se as pesquisas realizadas no Corpus Brasileiro e no Cdp, onde não há registros de tal construção. O empenho de maior expressividade do autor, aqui registrada pelo uso da metonímia "com olhos trinta anos mais velhos", foi integralmente recriado na tradução, "with eyes thirty years older", possibilitando ao leitor de língua inglesa ter a mesma experiência de leitura do leitor de língua portuguesa. Cabe ressaltar que o uso do substantivo "eyes" acompanhado de uma expressão temporal com as mesmas intenções do original não foi encontrado na pesquisa feita no corpus COCA, fato que confere à tradução igual teor de ineditismo do original no âmbito do referido corpus pesquisado. Expandindo o escopo da análise referente ao vocábulo "olhos" no contexto acima, notou-se que a expressão metafórica "a ouro e fio", não foi recuperada na tradução. Ao contrário, o tradutor optou pelo uso do advérbio "exactly", promovendo, desta forma, o apagamento da metáfora.

\section{1.a BUDPO: Meus olhos se} inundaram, minhas faces, meu rosto inteiro, a camisola de Kriska, suguei a camisola de Kriska para comprovar o sabor das lágrimas. 61.b BUDIT: My eyes flooded over on to my cheeks, my whole face, Kriska's nightie; I sucked Kriska's nightie to confirm the taste of my tears. 
No trecho acima, o substantivo "olhos" vem acompanhado do verbo "inundar", formando uma combinação incomum na língua portuguesa se considerarmos a pesquisa feita no Corpus Brasileiro, que não revelou nenhum registro de "olhos se inundaram". Contudo, a consulta realizada ao Corpus COCA mostrou um total de vinte e seis ocorrências de "eyes" com o colocado "flooded" em diferentes contextos, dentre eles: "Had she spoken too aggressively? The lady's lower lip quivered, her eyes flooded.". Em dez dessas vinte e seis ocorrências de "eyes" com o colocado"flooded", o sujeito do verbo "flood" é sempre lágrimas, como no seguinte exemplo extraído do referido corpus: "Tears flooded my eves, blurring my vision, but not enough to close out the grotesque image.". Em outros cinco casos, a combinação "eyes flooded" veio acompanhado de "with tears": "Watch his face, dismayed and dwindling, in the rear-view mirror. Eyes flooded with tears, she began quietly to laugh.".

Portanto, nesses casos o substantivo "tears" acompanhou com frequência a combinação "eyes flooded", seja como sujeito ou como complemento do verbo "flood". Tendo ressaltado a frequência do uso do substantivo "tears" nos contextos assim, cabe salientar que a tradutora optou por manter a intenção estilística do autor e omitiu o uso do substantivo "tears" na sequência "My eyes flooded", reservando-o para o final da frase como fez o autor com relação ao substantivo "lágrimas". Concluindo, observa-se que neste caso a ideia de superabundância expressada pelo verbo "inundar" no original, tendo "meus olhos" como sujeito, foi fielmente recriada pela tradução: "My eyes flooded". 


\section{Dados estatísticos e discussões}

\begin{tabular}{|c|c|c|c|c|c|c|c|c|}
\hline OBRA & TRADUTOR & $\begin{array}{c}\text { No total de } \\
\text { comb.criativas } \\
\text { analisadas }\end{array}$ & $\begin{array}{c}\text { No } \\
\text { recupera- } \\
\text { das }\end{array}$ & $\%$ & $\begin{array}{c}\text { No } \\
\text { parcialmente } \\
\text { recuperadas }\end{array}$ & $\%$ & $\begin{array}{c}\text { No não } \\
\text { recuperadas }\end{array}$ & $\%$ \\
\hline ESTORVO & P. Bush & $\mathbf{3}$ & 2 & $66,66 \%$ & 0 & $0 \%$ & 1 & $33,33 \%$ \\
\hline BENJAM IM & C. Landers & $\mathbf{5}$ & 3 & $60 \%$ & 1 & $20 \%$ & 1 & $20 \%$ \\
\hline BUDAPESTE & A. Entrekin & $\mathbf{7}$ & 7 & $100 \%$ & 0 & $0 \%$ & 0 & $0 \%$ \\
\hline \multicolumn{2}{|c|}{ TOTAL } & $\mathbf{1 5}$ & 12 & $80 \%$ & 1 & $6,66 \%$ & 2 & $13,33 \%$ \\
\hline
\end{tabular}

Tabela 26 - Recuperação das combinações criativas nas obras de Chico Buarque pelos seus tradutores.

A tabela 22 permite visualizar quantitativamente o número de casos, em que a criatividade do autor foi recuperada, parcialmente recuperada ou não recuperada nos quinze casos acima analisados. No computo geral, os números indicam que a criatividade do autor foi recuperada em doze dos quinze casos analisados, ou em $80 \%$ dos casos analisados. É claro que não é prudente fazer generalizações com base nesta pequena amostragem, contudo é possível afirmar que, nesses casos específicos, houve por parte dos tradutores um esforço no sentido de recriar, na língua de chegada, não apenas os vários sentidos das palavras cuidadosamente lapidadas pelo autor, como também o estilo do discurso buarqueano. Cabe salientar que, para se chegar a esta restrita seleção de palavras-chaves e dentre elas pinçar o que seria mais representativo da criatividade do autor para ser analisado, percorreu-se um longo caminho, investigando com olhos bem atentos as nuances semânticas e estilísticas dos textos originais e traduzidos. Portanto, é possível acreditar que há fortes indícios que esse compromisso com o resgate das supostas intenções do autor registrado nos casos analisados permeie as traduções em suas totalidades, principalmente no que diz respeito às construções estilísticas que envolvem a quebra dos padrões lexicais, como aqueles acima analisados. 
Esses indícios ganham status de evidências quando se recorre às entrevistas, nas quais os tradutores e o autor, na condição de partícipe do processo tradutório, falam sobre suas práticas tradutórias e explicitam os seus pensares sobre 0 assunto.

Peter Bush, por exemplo, afirma que cada palavra do original tem o seu valor individual, o que não quer dizer necessariamente que se deva traduzir palavra por palavra. No que diz respeito às escolhas lexicais, a sua intenção como tradutor é recriar na tradução o impacto gerado por cada palavra do original. O seu objetivo maior como tradutor é recriar em inglês "a ressonância contida no estilo do original". Para ele, "a tradução correta é aquela que capta o ritmo original do livro". Na entrevista concedida a este pesquisador, Bush, reiterou o fato de que o estranhamento contido no livro Estorvo deveria ser recriado na tradução, e que foi a sua tarefa, como seria a de qualquer outro tradutor zeloso de seu ofício, se esforçar para isso acontecesse. Como pode ser constatado pelas análises realizadas nesta pesquisa, existe uma coerência entre sua retórica e sua prática tradutória.

Alison Entrekin declarou que visa, em suas traduções, resgatar as intenções originais do autor "quando é possível conhecê-las". Suas traduções, segundo ela, primam pelo objetivo de oferecer ao leitor da língua e cultura de chegada uma experiência de leitura semelhante a do leitor do original ("eu queria que o leitor desse a mesma gargalhada, na mesma hora, pelo mesmo motivo."). Como exemplo disso ela cita o desafio encontrado para reconstruir os jogos de palavras criados pelo autor. Quanto à estratégia de tradução por ela utilizada em suas traduções, ela é enfática ao dizer que não uma regra, cada caso é tratado individualmente. Não existe uma abordagem que sirva de 
referência para todos os casos. O seu propósito de se aproximar das supostas intenções do autor podem ser comprovado não só pelas suas declarações, mas também pelas suas traduções que foram analisadas nesta pesquisa.

Clifford Landers foi o único entre os três tradutores que, em sua entrevista, posicionou-se a favor de uma tradução comprometida com o leitor e com a cultura de chegada: "se tenho que dar privilégio ou preferência ao autor ou ao leitor potencial, eu opto pelo segundo". Pode-se dizer que este posicionamento teórico tem um reflexo direto na sua prática como tradutor, as análises de suas traduções ratificam a sua postura a favor de uma tradução mais fluente e transparente. $O$ tradutor afirmou também que a sua abordagem sempre foi a de favorecer o entendimento do leitor.

Concluindo, é possível dizer as traduções analisadas se aproximam dos originais no que diz respeito ao resgate das intenções criativas do autor. Neste contexto, elas são evidenciadas pela quebra da convencionalidade, ou seja, pela manipulação da linguagem cotidiana, remetendo o leitor a sentidos diversificados e inesperados. Há de considerar que um provável motivo para que as traduções analisadas sejam consideradas mais voltadas para o texto original seja o fato de o autor ter atuado como partícipe das traduções. As entrevistas confirmam que a participação de Chico Buarque na tradução influenciou várias escolhas dos tradutores. 


\section{CONCLUSÃO}

Este trabalho de pesquisa, que teve como objetivo investigar as traduções para o inglês de Estorvo, Benjamim e Budapeste, de autoria de Chico Buarque e suas respectivas traduções (Turbulence, Benjamim e Budapest), realizadas por Peter Bush, Clifford Landers e Alison Entrekin, respectivamente, fez uso da base metodológica a Linguística de Coprus e contou com um acervo de quatro entrevistas realizadas por este pesquisador, com o autor, os três tradutores e a editora Liz Calder. Essas entrevistas não fizeram parte do objetivo central desta pesquisa, mas foram um recurso adicional para se desenvolver este trabalho.

Foi constatado, neste trabalho, que a Linguística de Corpus mostrou-se de grande valia para a observação e a investigação deste corpus literário. Como base metodológica, ela permitiu que fossem identificados eventos linguísticos que não seriam perceptíveis a olho nu, ou seja, pelo cotejo manual entre as obras originais e suas traduções, devido à dimensão do corpus investigado. O programa computacional WordSmith Tools, selecionado para se fazer o levantamento quantitativo dos elementos textuais do referido corpus, colocou à disposição deste pesquisador informações que serviram como ponto de partida para se desenvolver uma análise qualitativa das referidas traduções. Por meio do utilitário KeyWords, que gera as palavras-chave do corpus de estudo ao compará-lo como um corpus de referência, foi possível identificar a presença marcante de um campo semântico relacionado às palavras que fazem parte do corpo humano, indicando ser está uma das características lexicais da obra de Chico Buarque. Como palavras isoladas não dizem tudo 
sobre o texto, partiu-se para o exame dessas palavras em contextos, utilizando-se o utilitário Concord e o software ParaConc. Pelo cotejo entre as obras originais e suas respectivas traduções, percebeu-se a presença de combinações lexicais criativas, geradas a partir da quebra da convencionalidade linguísitca, como nos seguintes casos que foram, dentre outros, analisados: "[...] julgei escutar um ruído de olhos a me seguir" e "[...] seus olhos fugiram do assunto".

A pesquisa em torno desses eventos linguísticos foi realizada, primordialmente, com o objetivo de verificar empiricamente se a criatividade do autor nesses casos específicos foi recriada nas traduções, e de quais estratégias os tradutores lançaram mão para que isso viesse a acontecer.

A conclusão baseada em uma amostragem foi a de que, de fato, as traduções foram próximas aos originais, e que presumivelmente houve, por parte dos tradutores, um empenho no sentido de recuperar as supostas intenções do autor. Esta forte intenção dos tradutores de recriar o estilo do discurso buarqueano em suas obras traduzidas foi corroborada pelos depoimentos dos próprios tradutores.

O fato de os resultados das análises terem apontado em direção a um tipo de tradução mais próxima do original, buscando o resgate das supostas pretensões semânticas e estilísticas do autor, deve estar também relacionado à participação ativa do autor nas traduções de suas obras para o inglês. As entrevistas com os tradutores, editora e o próprio autor, evidenciam que Chico Buarque, confirmando a sua reputação de pai zeloso de suas produções artísticas, trabalhou em cooperação com os seus tradutores durante todo o percurso de realização das traduções. Embora tenha afirmado não ser partícipe 
de suas traduções para a língua inglesa, por julgar que seu nível de proficiência nesta língua permite-lhe apenas apontar equívocos de tradução, ele se considera, na condição de autor, investido de autoridade sobre sua criação literária. Chico Buarque declarou também, em sua entrevista, que suas discussões com os tradutores acerca da tradução de uma palavra ou frase chegam a gerar "desavenças", "chegam a um ponto de quase ruptura". Contudo, ele considera o tradutor um "parceiro", um "intermediário" entre as duas línguas e culturas envolvidas no processo tradutório.

Outro fator que pode ter influenciado indiretamente nos resultados das traduções da obra de Chico Buarque para o inglês é a política editorial da Bloomsbury. Liz Calder revelou em sua entrevista que a referida editora concede total liberdade aos seus tradutores e promove a interação entre os sujeitos que participam do processo tradutório: autor, tradutor e editor. Para ela, o importante na obra literária é a voz do autor, e tradução deve tentar "captar a voz do autor" ou "a mais similar possível". Existe, por parte dessa casa editorial, um interesse diferenciado por traduções de autores estrangeiros, pois, na concepção de Liz Calder, a publicação de literatura de outras culturas é muito importante porque "abre os olhos do leitor para o resto do mundo".

A pesquisa baseada em corpora apontou caminhos que inicialmente não se pensava percorrer, comprovando que a Linguística de Corpus não é apenas uma metodologia, mas uma abordagem. O interesse pelas traduções de expressões convencionais e idiomáticas - envolvendo as palavras pertencentes ao campo semântico relacionadas às partes do corpo humano - surgiu ao longo da investigação. O foco principal desta pesquisa é investigar a criatividade constituída a partir da quebra da convencionalidade. Contudo, investigaram-se, 
também, alguns casos relacionados à recuperação da convencionalidade na tradução. As expressões convencionais e idiomáticas são um terreno fértil para se realizar pesquisas na área de tradução. Como Chico Buarque relatou em sua entrevista, elas tendem a impor dificuldades para os tradutores porque envolvem referências culturais que são, às vezes, instransponíveis, exigindo que o tradutor tenha, além de habilidade linguística, consciência desses fatores para que possa oferecer ao leitor da língua de chegada a possibilidade de uma experiência de leitura compatível com a do leitor da obra original.

O conjunto das cinco entrevistas realizadas por este pesquisador cumpriu satisfatoriamente o seu propósito de dialogar com os resultados da pesquisa realizada no corpus. Cabe ressaltar que se trata de um material rico em informações para o desenvolvimento de futuras pesquisas relacionadas aos diferentes perfis dos tradutores, suas crença e práticas.

Nesta pesquisa, não se teve a pretensão de fazer generalizações acerca das traduções dos três romances analisados, nem julgar a legitimidade das opções feitas pelos seus tradutores ou argumentar sobre os diferentes métodos de traduzir. Contudo, cabe salientar que, no contexto desta pesquisa, as traduções mais próximas do original aconteceram nos casos em que a intenção criativa do autor foi mais perceptível. Em outros casos, prevaleceu a opção pelo uso convencional da língua, indicando que houve uma alternância nos diferentes métodos de traduzir, não havendo espaço para as dicotomias rígidas entre traduções voltadas para o autor ou para o leitor ${ }^{147}$ ou domesticadoras $x$

\footnotetext{
${ }^{147}$ Em uma palestra proferida em 1813, o filósofo Friedrich Schleiermacher, citado por Lefevere (1992), argumenta que há apenas dois tipos de tradução: aquela em que o tradutor transporta o leitor para perto do autor ou aquela em que o tradutor leva o autor até o leitor.
} 
estrangeirizadoras $^{148}$, elas tenderam a se diluír em uma variedade de soluções negociadas caso a caso pelos tradutores. Os relatos dos tradutores confirmam que intenção predominante de cada um deles foi criar em seu próprio leitor o efeito do original.

A criatividade no campo lexical consiste não somente em cunhar uma nova palavra, um termo ou uma expressão, mas também em usar de forma criativa aquilo que já é consagrado na língua. Transformar elementos linguísticos comuns, de uso cotidiano, em pérolas de linguagem é também um ato de criatividade lexical, tão genuíno quanto um neologismo. Se o sonho de Chico Buarque era ser Guimarães Rosa, acredita-se que ele pode se dar por satisfeito. As análises focadas no léxico das obras de Chico Buarque e suas traduções, realizadas sob as lentes da Linguística de Corpus, mostraram uma variedade de combinações criativas: "olhos em ziguezague" ["zigzagging eyes","her eyes zigzagging"]; "olhos trinta anos mais velhos" ["eyes thirty years older"]; "seus olhos fugiram do assunto"["her eyes avoiding the topic"]; "julguei escutar um ruído de olhos" ["I thought I heard the sound of eyes"]; "seus olhos [...] gravitando" ["his eyes bobbing"]; "olhos daquele dia" ["that day's eyes"]; "seus olhos saracoteiam" ["his eyeballs dance"]; "seus olhos [....] cheiram a canela" ["her eyes have the scent of cinnamon"]; "seus olhos voltam a se encharcar" ["his eyes bleary this time"]. Quanto aos tradutores, as análises indicaram que eles se esmeraram em seus papéis de mediadores lingüísticos e culturais para oferecer aos seus leitores o efeito mais próximo possível do

\footnotetext{
${ }^{148}$ Venuti (1995), ao retomar a máxima de Schleiermacher, afirma que o autor permite ao tradutor a escolha entre dois métodos: o domesticador, que implica a adequação, a redução etnocêntrica do texto estrangeiro aos valores culturais do texto de chegada, levando dessa forma, o autor de volta para casa, e o método estrangeirizador, que, por sua vez, envia o leitor para a cultura de partida, permitindo-Ihe vivenciar uma outra cultura e conhecer outros valores por meio desse texto.
} 
original; para se "ter olhos de ler o que há de belo" ["to have eyes to read beautiful things"] e ouvidos para perceber a ressonância das vozes de Chico Buarque em inglês.

São essas as delimitações desta tese, cujos resultados, espero, possam ter contribuído para mostrar, através da lupa da Linguística de Corpus, como essa abordagem pode, a partir de dados quantitativos, contribuir para uma análise qualitativa de traduções de textos literários, corroborando ou refutando hipóteses elaboradas em princípio de forma intuitiva. Com esta pesquisa, espero, ainda, ter contribuído para ampliar a interface da Linguística de Corpus com a pesquisa na área da tradução. 


\section{REFERÊNCIAS}

ALBERT, André. "Narrador em amadurecimento" (entrevista). Revista Bravo (edição especial). São Paulo: Editora Abril, Dezembro de 2009, p.45-53.

AZEVEDO, Francisco Ferreira dos Santos. Dicionário Analógico da Língua Portuguesa. Rio de Janeiro: Lexikon, 2010. 1를. 1950.

BERBER SARDINHA, Tony. "Usando WordSmith Tools na investigação da linguagem". DIRECT Papers 40, 1999.

"Corpora Eletrônicos na Pesquisa em Tradução". In: Tagnin, S.E.O. (Org). Caderno de tradução: Corpora e Tradução. Florianópolis NUT, 2002, v.1.n.9.p.15-59.

Linguística de Corpus. Barueri, São Paulo: Editora Manole, 2004.

\& ALMEIDA, Gladis Maria de Barcellos. "A Linguística de Corpus no Brasil". In: TAGNIN, Stella \& Oto Vale. Avancços da Linguísitca de Corpus no Brasil: Pesquisa e Crítica. São Paulo: Humanitas, 2008, p. 17-40

BERNARDES GONÇALVES, Lourdes. "Linguística de corpus e análise literária: o que revelam as palavras-chave". In: TAGNIN, Stella \& Oto Vale. Avancços da Linguísitca de Corpus no Brasil: Pesquisa e Crítica. São Paulo: Humanitas, 2008, p. 387-405.

BOWKER, Lynne \& PEARSON Jenifer. Working with Specialized Language: A practical guide to using corpora. London: Routledge, 2002.

BUARQUE, Chico. Benjamin. São Paulo: Companhia das Letras, 1995.

, Chico. Benjamin. Trad. Clifford E. Landers. London: Bloomsbury, 1998. 1‥ ed. 1997.

, Chico. Budapeste. São Paulo: Companhia das Letras, 2003.

, Chico. Budapeste. Trad. Alinson Entrekin. London: Bloomsbury, 2004. 1991.

, Chico. Estorvo. 2. ed. São Paulo: Companhia das Letras, 2004. 1a. ed.,

, Chico. Turbulence. Trad. Peter Bush. London: Bloomsbury, 1997. 1ª ed. 1992.

Chico. Leite derramado. São Paulo: Companhia das Letras, 1를. 2009.

Collins Cobuild Advanced Learner's English Dictionary. Glasglow, Collins Cobuild, 2004 
DAFLON, Maria Lúcia. "A Quem Interessa?" In: PIETROLUONGO, Márcia Atálla (Org.) O trabalho da tradução. Rio de Janeiro: Contra Capa Livraria Ltda, 2009. p. 113-122.

DAVIES, Mark.; FERREIRA, Michael. (2006-) Corpus do Português (45 milhões de palavras, sécs. XIV-XX). Disponível em http://www.corpusdoportugues.org.

Dicionário Aurélio da Língua Portuguesa. Rio de Janeiro: Editora Nova Fronteira, 1986.

DUBOIS, Jean et al. Dicionário de Linguística, Trad. BARROS, Frederico. São Paulo: Cultrix, 1993.

ECO, Humberto. Quase a Mesma Coisa. Trad. Eliana Aguiar. Rio de Janeiro: Record, 2007.

. Mouse or Rat? Translation as Negotiation. London: Phoenix, 2003.

FERNANDES, Rinaldo. (Org.) Chico Buarque do Brasil. Rio de Janeiro: Fundação Biblioteca Nacional, 2004.

GERBER, Regina e Vera Valilévski. Um Percurso para Pesquisas com Base em Corpus. Forianópolis: Editora UFSC, 2007.

HOEY, M. Introduction. In: Hoey, M, (org.). Data, descripition, discourse: papers on the English Language in honour of John $\mathrm{McH}$. Sinclair on his sixthieth birthday. Londres, Harper-Collins, 1993, pv-ix

HUNSTON, Susan. "Methods in corpus linguistics: interpreting concordance lines". In: Corpora in applied linguistics. Cambridge: Cambridge University Press, 2002, p. 38-95.

Kenny, Dorothy. Lexis and Creativity in Translation. A Corpus-based Study.Manchester, UK \& Northampton MA: St. Jerome, 2001.

.LAJOLO, Marisa. "Chico Buarque: entre o real e o imaginário". In: O Estado de São Paulo de 31/08/1991.

LANDERS, Clifford. Literary Translation. A practical Guide. Tonawanda, NY: Multilingual Matters Ltd,.2001

LEFEVERE, Andre. Translation, rewriting \& manipulation of literature. London: Routledge, 1992.

Longman Dictionary of English Idioms. London: Editora Longman, London, 1992. 
MACHACO, Josué. "A dupla vida de Chico" (entrevista). Revista da Língua Portuguesa, Ano 1, № 08, 2006, p. 12-17.

McENERY, Tony \& WILSON, Andrew. Corpus Linguistics. An Introduction. Edinburgh: Edinburgh University Press, 200.

MEIHY, José Carlos Sebe. Manual de História Oral. São Paulo: Edições Loyola, 2002.

NEWMARK, Peter. About Translation.Tonawanda, NY: Multilingual Matters Ltd,.1991.

OLIVEIRA, Nelson."Liquidificador estorvado." In: Chico Buarque do Brasil, BERNARDES, Rinaldo (Org.). Rio de Janeiro: Garamond, 2004.p. 205-210. p. 101-106.

PEREIRA, Rogério. "Movimentos no vasto campo das dúvidas". In: Chico Buarque do Brasil, BERNARDES, Rinaldo (Org.). Rio de Janeiro: Garamond, 2004.p. 205-210. p. 101-106.

PESSOA, Marcelo. Estorvo uma crônica interrompida, 2008. História em reflexão, revista eletrônica Vol. 2 n.3 UFGD, 2008. Pesquisado em 18 de janeiros de 2010. Disponível em: WW.scrib.com/doc/2569198/Estorvo.

Programa WordSmith <www.lexically.net> SCOTT,Mike.1988.Oxford Univeristy Press, Oxford).

Revista OCAS, edição de 24/07/2004.

RIBEIRO, Carlos. "Romance do simulacro". In: Chico Buarque do Brasil, BERNARDES, Rinaldo (Org.). Rio de Janeiro: Garamond, 2004.p. p. 63-66.

SALLES. Cecília Almeida. "A literatura do Estorvo". In: Chico Buarque do Brasil, BERNARDES, Rinaldo (Org.). Rio de Janeiro: Garamond, 2004.p. 205-210.

SCOTT, Mike. WordSmith Tools. Oxford University Press, 1999. Disponível em http://www.lexically.net/wordsmith/ . Primeiro acesso em: 11/10/2005.

Programa WordSmith <www.lexically.net>(SCOTT,Mike.1988.Oxford Univeristy Press, Oxford).

SILVA, Fernando de Barros. Chico Buarque. São Paulo: Publifolha, 2004.

SNELL-HORNBY, Mary. The Turns of Translation Studies. Amsterdam: John Benjamins Publishing Company, 2006.

TAGNIN, Stella \& Oto Vale. Avanços da Linguísitca de Corpus no Brasil: Pesquisa e Crítica. São Paulo: Humanitas, 2008. 
O jeito que a gente diz. São Paulo: Disal Editora, 2005.

TAHIR-GURÇAGLAR, Sehnaz. What texts don't tell: The uses of paratexts in translation research. In Herman, Theo (ed.) Crosscultural Transgressions.

Manchester: St. Jerome Publishing, 2002, p. 44-60.

VENUTI, Lawrence. The Translator's Invisibility. London \& New York:

Routledge,1995.

ZAPPA, Regina. "Vertigem". In:Chico Buarque do Brasil, BERNARDES, Rinaldo (Org.). Rio de Janeiro: Garamond, 2004.p. 205-210. p.107-110.

ZIBERMAN, Regina. "Não é conversa mole pra boi dormir. "Fazenda Modelo", novela pecuária, in Chico Buarque do Brasil, Rinaldo de Fernandes, org. Rio de Janeiro: Garamond: Fundação Biblioteca Nacional, 2004, p. 363-370.

WERNECK, Humberto. Chico Buarque: Tantas Palavras. São Paulo: Companhia da Letras, 2006.

WILCOCK, J. The Temple of Iconoclasts, traduzido por Lawrence Venuti. San Francisco, CA: Mercury House, 2000. 
ANEXOS 
Anexo 1

Roteiro da entrevista com o tradutor Clifford Landers 
1. Quais as estratégias (e os paradigmas teóricos a elas subjacentes) que nortearam a sua tradução de Benjamim?

2. Você acha que o leitor de língua inglesa lê o seu texto como se tivesse sido escrito originalmente em inglês? Você teve esse tipo de preocupação ou intenção?

3. Qual o papel da teo ria de tradução na sua prática como tradutora literária?

4. Como você descreveria o seu processo de tradução. Em particular, da tradução de Benjamim?

5. Você pode citar algumas peculiaridades relacionadas à tradução de Benjamim?

6. Berman afirma que a tradução faz girar a obra original, ou seja, a tradução revela dela uma outra vertente. Você pode citar algum exemple que corrobore essa afirmação?

7. a. Na sua opinião, a quem, a que tipo de leitor, se destinam as traduções de obras literárias oriundas de culturas periféricas com a nossa?

b. As características desses leitores influem nas suas opções como tradutor?

8. De que forma a política editorial da Bloomsbury norteou e/ou interferiu em sua tradução? De um modo geral, de que forma a tradução é afetada por esse fator?

9. Chico Buarque revelou em algumas de suas entrevistas que participou das traduções de suas obras para 0 inglês, francês e italiano. Essa participação aconteceu na tradução de Budapeste? Qual 0 grau de interferência/participação do autor? De que forma esse diálogo ocorreu? É possível definir o estilo literário de Chico Buarque?

10. Como foi a resposta da crítica à sua tradução? Existe alguma interação entre a crítica e você? Existe alguma interação entre você o público leitor de suas traduções?

11. De acordo com Venuti, a obra traduzida é legitimada por editores, críticos e leitores quando se apresenta fluente, ou seja, quando não causa nenhum tipo de estranhamento ao leitor da língua de chegada. Conseqüentemente, "quanto mais bem sucedida a tradução mais invisível o tradutor, e mais visível 0 autor ou o significado do texto original" (1986). Você concorda com essa afirmação? Por quê?

12. No que concerne à teoria e prática de tradução, Marilyn Rose (1993), argumenta que atualmente vivenciamos um novo literalismo, ou seja, o renascimento do literalismo, uma prática de tradução que está historicamente 
relacionada à tradução palavra por palavra. Você acredita que essa tendência tem influenciado o seu trabalho de tradutor literário?

13. Em palestra proferida em 1813, o filósofo Friedrich Schleiermacher, citado por Lefevere (1992), argumenta que há apenas dois tipos de tradução: aquela em o tradutor transporta o leitor para perto do autor e aquela em o tradutor leva 0 autor até o leitor. Como tradutor você considera essas alternativas na sua prática?

14. Você considera a sua tradução source ou target oriented?

15. Que considerações adicionais você gostaria de fazer sobre a tradução de Benjamim?

Anexo 2

Word Lists - Listas de Palavras-Chave

\begin{tabular}{|c|c|c|c|c|}
\hline Anexos n- & $\begin{array}{c}\text { Sigla das WL } \\
\text { (Lista de }\end{array}$ & Obra & $\begin{array}{c}\text { Corpus de } \\
\text { estudo }\end{array}$ & $\begin{array}{c}\text { Corpus de } \\
\text { Referência }\end{array}$ \\
\hline
\end{tabular}




\begin{tabular}{|c|c|c|c|}
\hline & Freqüência) & & \\
\hline 2.1 & WLESTPO & $\begin{array}{l}\text { Estorvo } \\
\text { português } \\
\text { original }\end{array}$ & \\
\hline 2.2 & WLBENPO & $\begin{array}{l}\text { Benjamim } \\
\text { português }\end{array}$ & \\
\hline 2.3 & WLBUDPO & $\begin{array}{c}\text { Budapeste } \\
\text { português } \\
\text { original }\end{array}$ & \\
\hline 2.4 & WLESTIT & $\begin{array}{c}\text { Estorvo inglês } \\
\text { traduzido }\end{array}$ & \\
\hline 2.5 & WLBENIT & $\begin{array}{l}\text { Benjamim } \\
\text { inglês } \\
\text { traduzido }\end{array}$ & \\
\hline 2.6 & $\overline{\text { WLBUDIT }}$ & $\begin{array}{l}\text { Budapeste } \\
\text { inglês } \\
\text { traduzido }\end{array}$ & \\
\hline 2.7 & WLCEPO & & $\begin{array}{l}\text { Português } \\
\text { original }\end{array}$ \\
\hline 2.8 & WLCEIT & & $\begin{array}{c}\text { Inglês } \\
\text { traduzido }\end{array}$ \\
\hline
\end{tabular}

Anexo 3

\section{Keyword Lists - Listas de Palavras-Chave}

\begin{tabular}{|c|c|c|c|}
\hline Anexos no & Siglas das KWL & Corpus de Estudo & Corpus de referência \\
\hline & & & \\
\hline 3.1 & KWESTPO3 & Estorvo (WLESTPO) & Banco de Português \\
\hline
\end{tabular}




\begin{tabular}{|c|c|c|c|}
\hline 3.2 & KWBENPO3 & $\begin{array}{c}\text { Benjamim } \\
\text { (WLBENPO) }\end{array}$ & $\begin{array}{c}\text { (WLCRCO de Português } \\
\text { (WLCRPO3) }\end{array}$ \\
\hline 3.3 & KWBUDPO3 & $\begin{array}{c}\text { Budapeste } \\
\text { (WLBUDPO) }\end{array}$ & $\begin{array}{c}\text { Banco de Português } \\
\text { (WLCRPO3) }\end{array}$ \\
\hline 3.4 & KWESTIT2 & $\begin{array}{c}\text { Estorvo Inglês } \\
\text { Traduzido } \\
\text { (WLESTIT) }\end{array}$ & BNC (WLCRIN2) \\
\hline 3.5 & KWBENIT2 & $\begin{array}{c}\text { Benjamim Inglês } \\
\text { Traduzido } \\
\text { (WLBENIT) }\end{array}$ & BNC (WLCRIN2) \\
\hline 3.6 & KWBUDIT2 & $\begin{array}{c}\text { Budapeste Inglês } \\
\text { Traduzido } \\
\text { (WLBUDIT) }\end{array}$ & BNC (WLCRIN2) \\
\hline 3.7 & KWCEPO3 & $\begin{array}{c}\text { Corpus de estudo } \\
\text { português original } \\
\text { (WLCEPO) }\end{array}$ & $\begin{array}{c}\text { Banco de português } \\
\text { (WLCRPO3) }\end{array}$ \\
\hline 3.8 & KWCEIT2 & $\begin{array}{c}\text { Corpus de estudo } \\
\text { inglês traduzido } \\
\text { (WLCEIT) }\end{array}$ & BNC (WLCRIN2) \\
\hline
\end{tabular}

\section{Anexo 4}

Capas:

segunda edição de Estorvo, 2004

primeira edição de Benjamim, 1995

segunda edição de Budapeste, 2005 
Anexo 5

Capa e folha de rosto: segunda edição de Turbulence, 1997 
Anexo 6

Capa e folha de rosto:

segunda edição de Benjamin, 1998 


\section{Anexo 7}

Capa e folha de rosto:

primeira edição de Budapest, 2004 
